Prepared in cooperation with Douglas County and the Carson Water Subconservancy District

\title{
The Distribution and Modeling of Nitrate Transport in the Carson Valley Alluvial Aquifer, Douglas County, Nevada
}

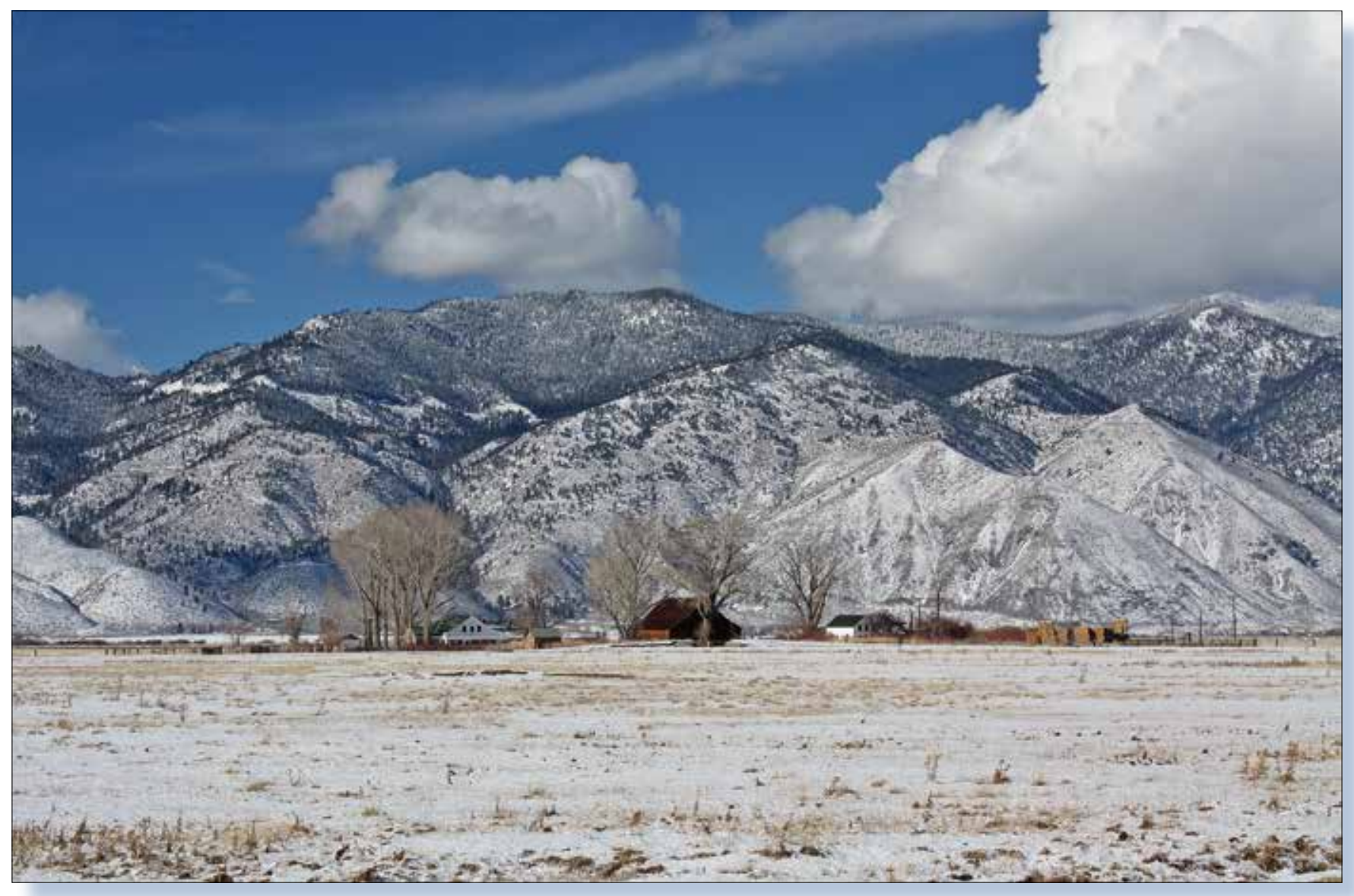

Scientific Investigations Report 2013-5136 



\section{The Distribution and Modeling of Nitrate Transport in the Carson Valley Alluvial Aquifer, Douglas County, Nevada}

By Ramon C. Naranjo, Toby L. Welborn, and Michael R. Rosen

Prepared in cooperation with Douglas County and the Carson Water

Subconservancy District

Scientific Investigations Report 2013-5136 


\title{
U.S. Department of the Interior Sally Jewell, Secretary
}

\section{U.S. Geological Survey Suzette M. Kimball, Acting Director}

\author{
U.S. Geological Survey, Reston, Virginia: 2013
}

For more information on the USGS - the Federal source for science about the Earth, its natural and living resources, natural hazards, and the environment, visit http://www.usgs.gov or call 1-888-ASK-USGS.

For an overview of USGS information products, including maps, imagery, and publications, visit http://Www.usgs.gov/pubprod.

To order this and other USGS information products, visit http://store.usgs.gov.

Any use of trade, firm, or product names is for descriptive purposes only and does not imply endorsement by the U.S. Government.

Although this information product, for the most part, is in the public domain, it also may contain copyrighted materials as noted in the text. Permission to reproduce copyrighted items must be secured from the copyright owner.

Suggested citation:

Naranjo, R.C., Welborn, T.L., and Rosen, M.R ., 2013, The distribution and modeling of nitrate transport in the Carson Valley alluvial aquifer, Douglas County, Nevada: U.S. Geological Survey Scientific Investigations Report 2013-5136, $51 \mathrm{p.}$ 


\section{Contents}

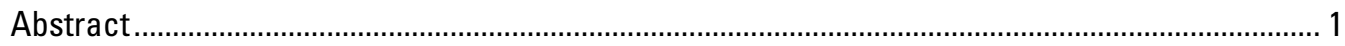

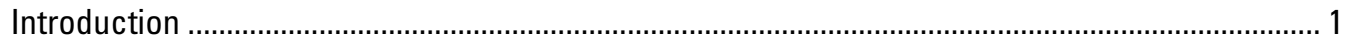

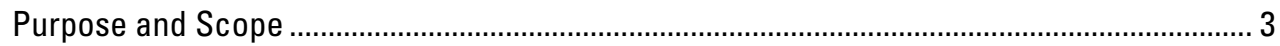

Description of Study Area .............................................................................................. 3

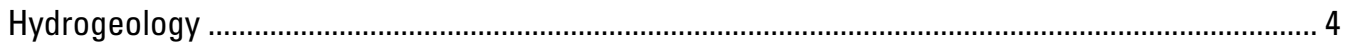

Data Collection and Analysis ................................................................................................ 4

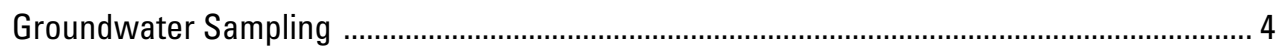

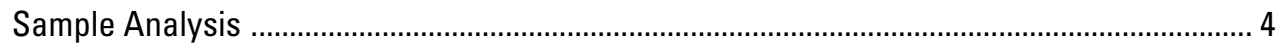

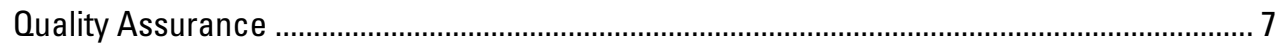

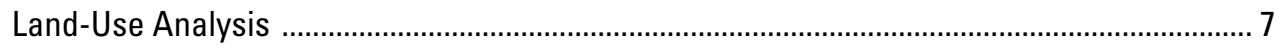

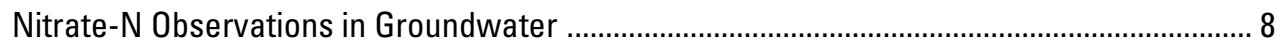

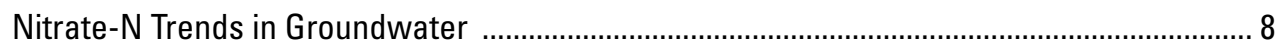

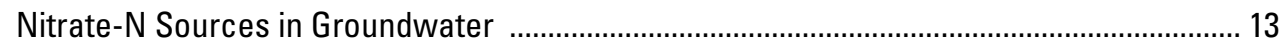

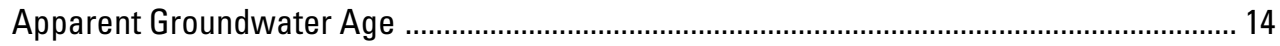

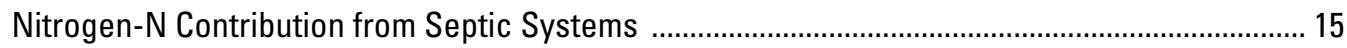

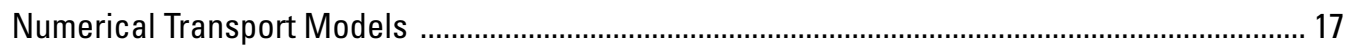

Groundwater Flow and Transport-Model Design ............................................................... 17

Nitrate-N Transport in the Unsaturated Zone ................................................................ 17

Nitrate-N Transport in the Saturated Zone ................................................................... 19

Domestic wells and septic systems ......................................................................... 19

Transport Parameters and Assumptions ............................................................... 22

Numerical Transport-Model Results and Discussion ............................................................ 22

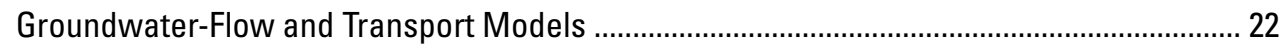

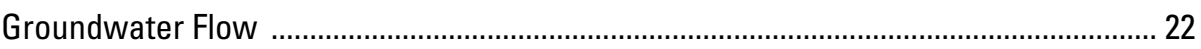

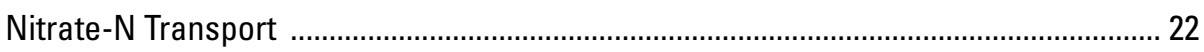

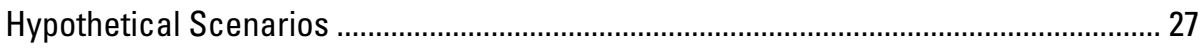

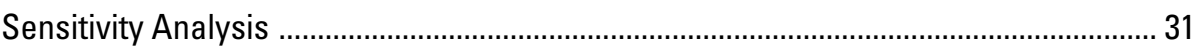

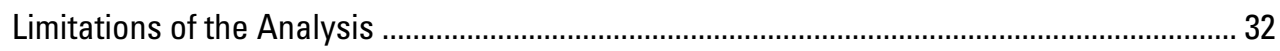

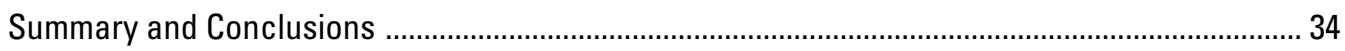

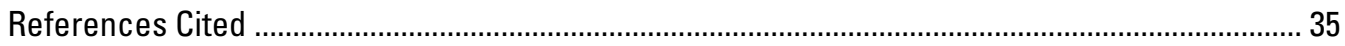

\section{Figures}

1. Map showing location of major drainages, major roads, and areas with septic systems and monitoring wells sampled in Carson Valley, Douglas County,

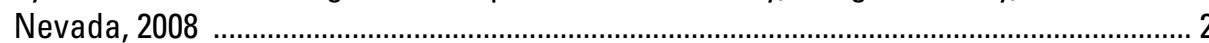

2. Graph showing population and total number of septic systems for Douglas County, Nevada, 1860-2008 ................................................................................................ 3

3. Geologic cross-section of Carson Valley, Nevada, shown from transect $A$ in figure 1 ....... 5

4. Map showing spatial distribution of land use and sampled wells, Douglas county, Nevada, 2008 
5. Map showing nitrate-nitrogen concentrations in milligrams per liter in sampled wells and parcels with septic systems in Carson Valley, Douglas County,

Nevada, 2008-09

6. Graph showing geochemical results for sampled wells for the 2008-09 sampling events. Nitrate compared to $A$, dissolved oxygen; $B$, chloride; $C$, screen depth; and $D$, specific conductance

7. Graph showing range of nitrate as nitrogen concentrations relative to land-use and percentage of land use: $A$, single-family residential; $B$, residential multifamily; $C$, rural; and $D$, vacant land

8. Graph showing cumulative frequency of observed nitrate as nitrogen concentrations for Carson Valley, Douglas County, Nevada 1980-2010

9. Graph showing geochemical results for wells sampled for $A$, nitrogen and oxygen isotopes of nitrate; $B$, tritium; and $C$, chlorofluorocarbons; and $D$, mean nitrate concentrations associated with parcel size

10. Schematic diagram representing $A$, sources of nitrate as nitrogen (N) from septic systems as a result of oxidation of ammonia or urea leaching to groundwater and removal from domestic pumping; $B$, modeling approach for simulating nitrate- $\mathrm{N}$ transport in the unsaturated and saturated zones; and $C$, the stoichiometry for the denitrification process

11. Graph showing septic-system densities required to maintain nitrate as nitrogen concentrations less than 10 milligrams per liter, as a function of effluent concentration, or $\mathrm{Np}$, in milligrams per liter, and recharge rate, in inches per year

12. Map showing the boundaries of the Carson Valley regional groundwater-flow model from Yager and others (2012) and the transport models for the Johnson Lane and Ruhenstroth areas in Carson Valley, Nevada and California

13. Graph showing VS2DT solute-breakthrough curves for different depths below land surface and mean arrival-time regression equation used for interpolation of results to Johnson Lane and Ruhenstroth transport models

14. Diagrams showing the spatial distribution of input data for Johnson Lane hypothetical models: $A$, Log of hydraulic conductivity; $B$, Net recharge; and $C$, Boundary conditions and cells with wells and septic tanks

15. Diagrams showing the spatial distribution of input data for Ruhenstroth hypothetical models: $A$, Log of hydraulic conductivity; $B$, Net recharge; and $C$, Boundary conditions and cells with wells and septic tanks

16. Map showing hypothetical scenario model 2005 simulated water table compared to Carson Valley regional groundwater model 2005 simulated water table for $A$, Johnson Lane and $B$, Ruhenstroth in Carson Valley, Douglas County, Nevada

17. Graph showing $A$, The cumulative number of septic tanks by year; and $B$, diagrams showing the spatial distribution of arrival times for Johnson Lane and

$C$, Ruhenstroth transport models

18. Graphs and map showing observed 2008-09 compared to simulated 2009 nitrate as nitrogen $(\mathrm{N})$ concentrations for the Johnson Lane model 2009 time-step: $A$, Observed compared to simulated; $B, 0 \mathrm{bserved}$ compared to simulated at observation cells and all cells; and $C$, Map depicting spatial distribution of nitrate-N 2009 time step with observed nitrate-N concentrations for 2008-09 
19. Graphs and map showing observed 2008-09 compared to simulated nitrate as nitrogen (N) concentrations for the Ruhenstroth model 2009 time-step:

$A$, Observed compared to simulated; $B$, Observed compared to simulated at observation cells and all cells; and $C$, Map depicting spatial distribuiton of nitrate-N 2009 time step with observed Nitrate-N concentrations for 2008-09

20. Map showing distribution of simulated nitrate as nitrogen concentrations within the Johnson Lane and Ruhenstroth transport models from 1970-2059 for hypothetical scenarios of discontinued use of septic systems in 2030 and discontinued use of septic systems and domestic-well pumping in 2030 .

21. Diagrams showing distribution of simulated nitrate as nitrogen concentrations at Johnson Lane: $A, 2009 ; B, 2059 ; C, 2059$ discontinued use of septic systems in 2030; and $D, 2059$ discontinued use of septic systems and domestic-well pumping in 2030

22. Diagram showing distribution of simulated nitrate as nitrogen concentrations at Ruhenstroth: $A, 2009 ; B, 2059 ; C, 2059$ discontinued use of septic systems 2030; and $D, 2059$ discontinued use of septic systems and domestic-well pumping 2030 ..... 30

23. Graphs showing the cumulative distribution of simulated nitrate as nitrogen concentrations at 2009, 2059, and $\mathrm{H} 1$ and $\mathrm{H} 2$ scenarios with the removal of septic systems and domestic pumping at $A$, Johnson and $B$, Ruhenstroth areas

24. Graphs showing summary of concentrations at observations given incremental changes to transport parameters located at $A$, Johnson Lane, and $B$, Ruhenstroth model areas, where prediction corresponds to base case simulation

25. Graph showing nitrate as nitrogen concentration frequency plot for wells sampled in Spanish Springs, Washoe County, Nevada, 2008-09.

\section{Tables}

1. Quality-assurance data collected for this study 7

2. Correlation coefficients for select land-use and water-quality parameters ........................ 8

3. Kendall tau results for nitrate-nitrogen and total dissolved solids .................................... 12

4. Simulated maximum nitrate as nitrogen concentration, total area exceeding the maximum contaminant level of 10 milligrams per liter in 2009, 2059, and for the hypothetical scenarios where discontinued use of septic systems, and discontinued use of septic systems and domestic-well pumping .

\section{Appendix tables}

1. Field, nutrient, chloride, and bromide chemical data; and land use and number of septic tanks within 500 meters of each well

2. Tritium, chlorofluorocarbon, and dissolved gas (nitrogen, argon, oxygen, carbon dioxide, and methane) data for selected wells

3. Nitrogen and oxygen isotope data for selected wells

4. Field and lab chemical data for nitrogen, bromide, and chloride for selected wells 


\section{Conversion Factors and Datums}

Inch/Pound to SI

\begin{tabular}{|c|c|c|}
\hline Multiply & By & To obtain \\
\hline \multicolumn{3}{|c|}{ Length } \\
\hline foot $(\mathrm{ft})$ & 0.3048 & meter (m) \\
\hline inch (in) & 25.4 & millimeter (mm) \\
\hline mile (mi) & 1.609 & kilometer $(\mathrm{km})$ \\
\hline \multicolumn{3}{|c|}{ Area } \\
\hline acre & 0.4047 & hectare (ha) \\
\hline \multicolumn{3}{|c|}{ Flow rate } \\
\hline acre-foot per year (acre-ft/yr) & 1,233 & cubic meter per year $\left(\mathrm{m}^{3} / \mathrm{yr}\right)$ \\
\hline foot per day (ft/d) & 0.3048 & meter per day $(\mathrm{m} / \mathrm{d})$ \\
\hline \multicolumn{3}{|c|}{ Transmissivity } \\
\hline foot squared per day $\left(\mathrm{ft}^{2} / \mathrm{d}\right)$ & 0.09290 & meter squared per day $\left(\mathrm{m}^{2} / \mathrm{d}\right)$ \\
\hline
\end{tabular}

Temperature in degrees Celsius $\left({ }^{\circ} \mathrm{C}\right)$ may be converted to degrees Fahrenheit $\left({ }^{\circ} \mathrm{F}\right)$ as follows:

${ }^{\circ} \mathrm{F}=\left(1.8 x^{\circ} \mathrm{C}\right)+32$

Vertical coordinate information is referenced to the National Geodetic Vertical Datum of 1929 (NGVD 29).

Horizontal coordinate information is referenced to the North American Datum of 1983 (NAD 83).

Altitude, as used in this report, refers to distance above the vertical datum.

Specific conductance is given in microsiemens per centimeter at 25 degrees Celsius $(\mu \mathrm{S} / \mathrm{cm}$ at $\left.25^{\circ} \mathrm{C}\right)$.

Concentrations of chemical constituents in water are given either in milligrams per liter (mg/L) or micrograms per liter $(\mu \mathrm{g} / \mathrm{L})$.

\section{Acronyms and Additional Abbreviations}

$\begin{array}{ll}\text { CFC } & \text { chlorofluorocarbons } \\ \text { ET } & \text { evapotranspiration } \\ \text { ISE } & \text { ion specific electrode } \\ \text { MCL } & \text { maximum contaminant level } \\ \text { NWQL } & \text { National Water Quality Laboratory } \\ \text { USEPA } & \text { U.S. Environmental Protection Agency } \\ \text { USGS } & \text { U.S. Geological Survey }\end{array}$




\section{Acknowledgments}

Funding for this project was provided through a cooperative agreement between Douglas County, the Carson Water Subconservancy District, and the U.S. Geological Survey. Appreciation is extended to all homeowners, businesses, and public-water suppliers who participated in this study.

Many thanks also go to Doug Maurer, Keith Halford, Karen Thomas, Dick Yager of the USGS, and former student Joel Jacobson for their help in the field and laboratory, and for reviews of

draft manuscripts. The authors also wish to thank Richard Winston and Richard Niswonger (from USGS) for modeling support. 


\title{
The Distribution and Modeling of Nitrate Transport in the Carson Valley Alluvial Aquifer, Douglas County, Nevada
}

\author{
By Ramon C. Naranjo, Toby L. Welborn, and Michael R. Rosen
}

\section{Abstract}

Residents of Carson Valley in Douglas County, Nevada, rely on groundwater from an alluvial aquifer for domestic use and agricultural irrigation. Since the 1970s, there has been a rapid increase in population in several parts of the valley that rely on domestic wells for drinking water and septic systems for treatment of household waste. As a result, the density of septic systems in the developed areas is greater than one septic system per 3 acres, and the majority of the domestic wells are shallow (screened within 250 feet of the land surface).

The distribution of nitrate as nitrogen (referred to herein as nitrate-N) concentrations in groundwater was determined by collecting more than 200 samples from 8 land-use categories: single family residential, multifamily residential, rural (including land use for agriculture), vacant land, commercial, industrial, utilities, and unclassified. Nitrate- $\mathrm{N}$ concentrations ranged from below detection (less than 0.05 milligrams per liter) to 18 milligrams per liter. The results of nitrate-N concentrations that were sampled from three wells equalled or exceeded the maximum contaminant level of 10 milligrams per liter set by the U.S. Environmental Protection Agency. Nitrate-N concentrations in sampled wells showed a positive correlation between elevated nitrate- $\mathrm{N}$ concentrations and the percentage of single-family land use and septic-system density. Wells sampled in other land-use categories did not have any correlation to nitrate- $\mathrm{N}$ concentrations. In areas with greater than 50-percent single-family land use, nitrate- $\mathrm{N}$ concentrations were two times greater than in areas with less than 50 percent single-family land use. Nitrate-N concentrations in groundwater near septic systems that had been used more than 20 years were more than two times greater than in areas where septic systems had been used less than 20 years. Lower nitrate- $\mathrm{N}$ concentrations in the areas where septic systems were less than 20 years old probably result from temporary storage of nitrogen leaching from septic systems into the unsaturated zone.

In areas where septic systems are abundant, nitrate-N concentrations were predicted to 2059 by using numerical models within the Ruhenstroth and Johnson Lane subdivisions in the Carson Valley. Model results indicated that nitrate-N concentrations will continue to increase and could exceed the maximum contaminant level over extended areas inside and outside the subdivisions. Two modeling scenarios were used to simulate future transport as a result of removal of septic systems (source of nitrate-N contamination) and the termination of domestic pumping of groundwater. The models showed the largest decrease in nitrate- $\mathrm{N}$ concentrations when septic systems were removed and wells continued to pump. Nitrate- $\mathrm{N}$ concentrations probably will continue to increase in areas that are dependent on septic systems for waste disposal either under current land-use conditions in the valley or with continued growth and change in land use in the valley.

\section{Introduction}

Residents of Carson Valley in Douglas County, Nevada (fig. 1), rely on groundwater from an alluvial aquifer for domestic use and agricultural irrigation. Currently, there are more than 5,000 wells in the valley (Douglas County, 2006), most of which are private domestic wells screened within 250 feet (ft) of the land surface (State of Nevada, 2009). Since the 1970s, the valley has experienced a rapid increase in development and population, which has coincided with degradation of groundwater quality in some areas (Rosen, 2003; Shipley and Rosen, 2005). During the same period, septic systems have been installed at a rate of about 1,000 per decade in Douglas County (fig. 2).

In general, the high density of septic systems in a given area is the most important factor influencing groundwater contamination by septic systems (Yates, 1985). Elevated groundwater concentrations of nitrate-nitrogen (nitrate-N), chloride, and total dissolved solids are associated with septic systems (Canter and Knox, 1985; Williams and others, 1998; Rosen, 2003; Makowski, 2006; Morgan and others, 2007). Recent studies have shown elevated nitrate-N concentrations positively correlated to single-family land use in the Carson Valley and septic-system density (Shipley and Rosen, 2005). In addition, wells monitored by the U.S. Geological Survey (USGS) since the mid-1980s, have shown an increase in nitrate-N and total dissolved solids concentrations in several areas of the valley (Rosen, 2003).

Health risks associated with consumption of water having elevated nitrate- $\mathrm{N}$ concentrations have been documented since the 1940s. The research by Comly (1945) indicated a consistent pattern of high-nitrate- $\mathrm{N}$ drinking water in infantile methemoglobinemia cases. Methemoglobinemia, a disease in 


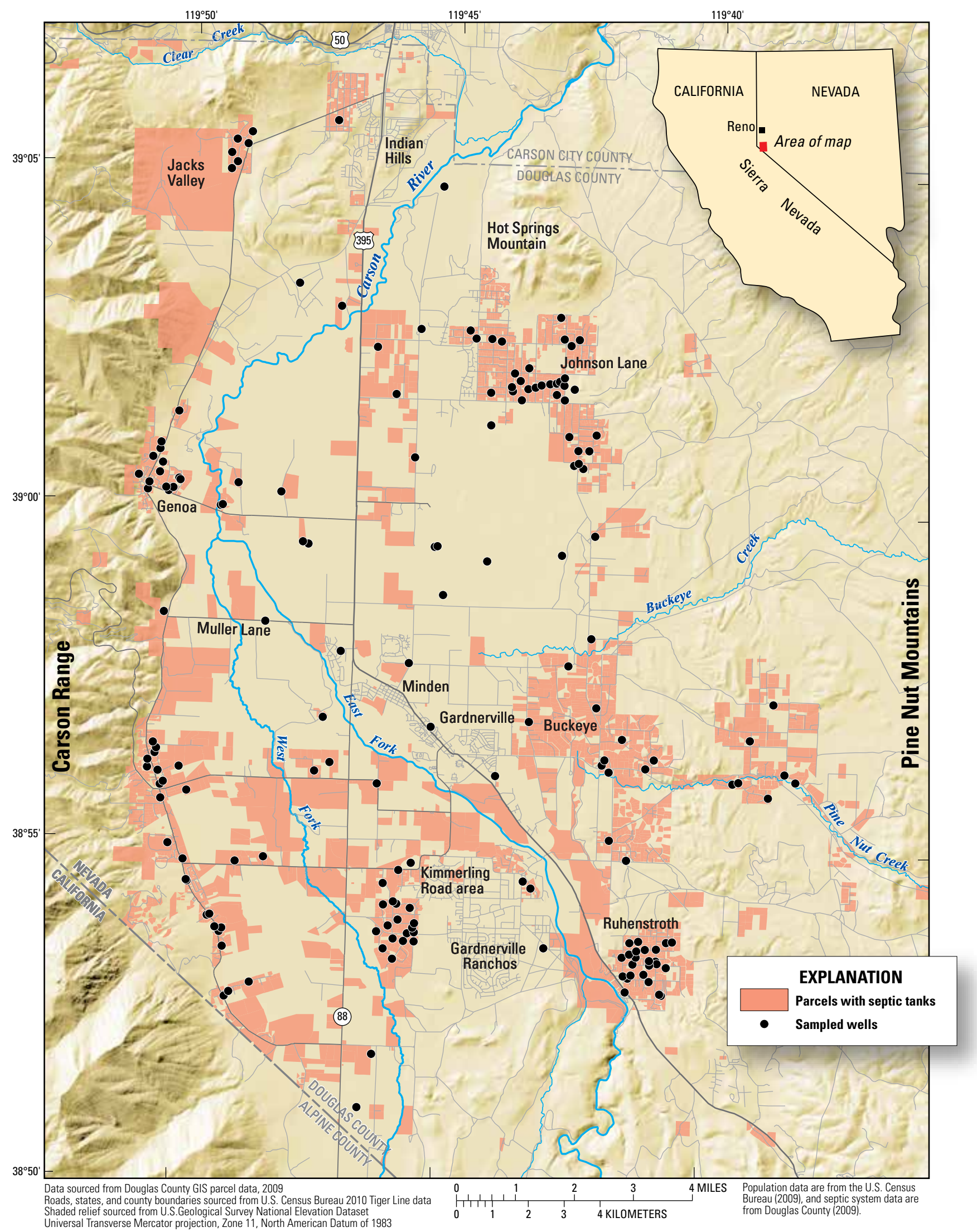

Figure 1. Location of major drainages, major roads, and areas with septic systems and monitoring wells sampled in Carson Valley, Douglas County, Nevada, 2008. 


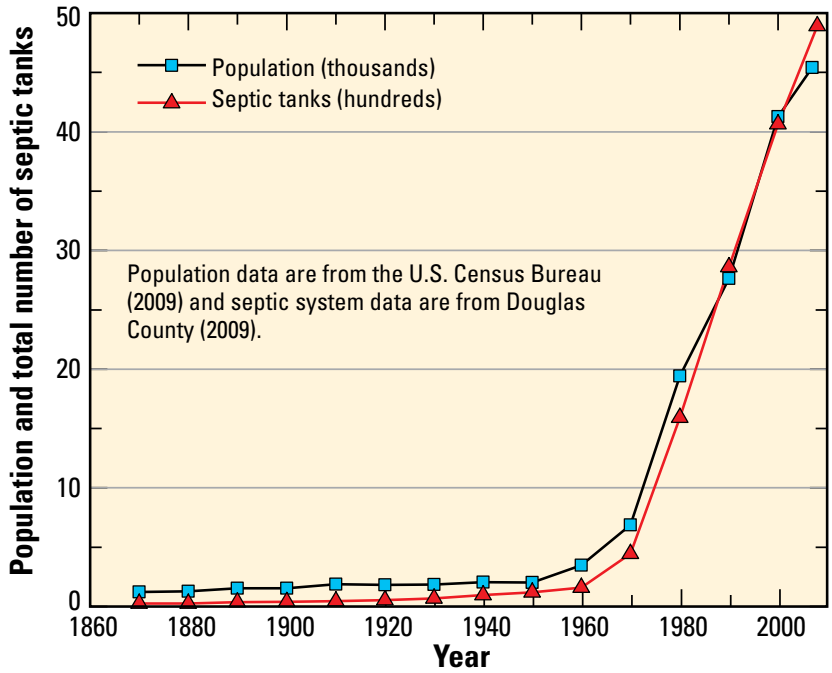

Figure 2. Population and total number of septic systems for Douglas County, Nevada, 1860-2008.

which hemoglobin is unable to carry oxygen, causes a bluish discoloration of the skin and can be fatal in infants under 6 months of age because they lack the enzyme that reduces methemoglobin to hemoglobin (Avery, 1999). As a result of the risk of methemoglobinemia, the U.S. Environmental Protection Agency (USEPA) established a maximum contaminant level (MCL) of 10 milligrams per liter $(\mathrm{mg} / \mathrm{L})$ for nitrate-N in 1975. In addition, consumption of nitrate- $\mathrm{N}$ has been linked to hypertension (Malberg and others, 1978), central nervous system birth defects (Super and others, 1981), certain types of cancer (Hill and others, 1973; Ward and others, 2005), and diabetes (Parslow and others, 1997).

Anthropogenic sources of nitrogen in Douglas County include agriculture (from the application of fertilizers or from animal waste), irrigation of treated waste water in fields and parks, urban and industrial runoff, and septic systems. The predominant form of organic nitrogen in septic systems is urea, which is converted to ammonia and ammonium through biological processes. The ammonia is then converted to nitrate in the presence of dissolved oxygen (aerobic conditions) in water. Natural sources of nitrogen in the groundwater are limited in Carson Valley, and nitrate concentrations in wells that have not been affected by human nitrogen sources generally are less than $1 \mathrm{mg} / \mathrm{L}$ as nitrogen (Rosen, 2003). Soil-core samples taken in the Pine Nut Mountains prior to this study (Douglas Maurer, U.S. Geological Survey, unpub. data, 2008), showed median extractable nitrate-N concentrations of less than $4.6 \mathrm{mg} / \mathrm{L}$, which is much lower than natural nitrate concentrations (up to $50 \mathrm{mg} / \mathrm{L}$ nitrate-N) in other northern Nevada alluvial sediments (Walvoord and others, 2003; Rosen and Kropf, 2009). These data indicate that no significant source of natural nitrogen is likely to be present in the study area.

Groundwater contamination from septic systems is common in aquifers that contain dissolved oxygen (Yates, 1985; Williams and others, 1998; Morgan and others, 2007) and has been observed in several other studies (for example, Miller,
1975; Perkins, 1984; Canter and Knox, 1985; and Reneau and others, 1989). A high septic density and steady discharge from septic systems have been shown to increase nitrate-N concentrations above the MCL over time (Makowski, 2006; Morgan and others, 2007). Studies that used predictive models generally concluded that nitrate- $\mathrm{N}$ concentrations will continue to increase when septic systems are used as the main wastewatertreatment system in an oxygenated aquifer (MacQuarrie and others, 2001; Conan and others, 2003; Makowski, 2006; Morgan and others, 2007).

Previous studies from specific areas of Carson Valley have shown that the source of elevated nitrate- $\mathrm{N}$ concentrations in groundwater comes from infiltration of septic-system wastewater into the shallow groundwater (Thodal, 1996; Thomas and others, 1999; Rosen, 2003; Shipley and Rosen, 2005). These studies were based on limited sampling in mostly residential areas of Carson Valley. To assess whether there are other important sources of nitrate-N to groundwater in Carson Valley and whether high concentrations exist in currently unsampled areas, a valley-wide study was needed to determine nitrate-N concentrations in groundwater under as many different types of land use as possible. In addition, an understanding of the transport of nitrate-N through the groundwater in Carson Valley and the possible long-term (50 years) effects of anthropogenic nitrate- $\mathrm{N}$ loading is needed to assess how water resources and water quality can be managed most effectively in the future.

\section{Purpose and Scope}

Previous studies based on limited geographic data have shown that nitrate concentrations in some areas of Carson Valley are increasing over time and that this increase is associated with septic-tank density (Rosen, 2003; Shipley and Rosen, 2005). In order to assess nitrate-N concentrations throughout Carson Valley and to predict concentrations of nitrate-N, a more detailed analysis of the valley was needed. The purpose of this report is to 1) analyze the spatial and temporal nitrate$\mathrm{N}$ concentrations in groundwater to quantify the relationship between concentration and land use, and 2) to simulate nitrate$\mathrm{N}$ transport under current and future conditions by using a numerical model of two subdivisions within Carson Valley for purposes of evaluating two scenarios for managing septicsystem usage.

\section{Description of Study Area}

The 400 square-mile $\left(\mathrm{mi}^{2}\right)$ study area of Carson Valley is located in Douglas County, Nevada, and Alpine County, California (fig. 1). The major population centers include the Minden/Gardnerville area, Gardnerville Ranchos, Kimmerling Road area, Johnson Lane, Genoa, Indian Hills, and Ruhenstroth (fig. 1). Land use for most of the valley has been agricultural, historically, but an increase in population has changed the dominant land-use classes to single-family residential and commercial (Maurer and Berger, 2006). 


\section{Hydrogeology}

Carson Valley is located in the rain shadow of the Sierra Nevada mountain range and had a 77-year average precipitation of $8.4 \mathrm{in} / \mathrm{yr}$ from 1928 to 2005 (Station 265191 Minden, Nevada) at the valley floor with more precipitation at higher elevations, mostly along the Carson Range. The Carson River flows through the center of Carson Valley and dominates the hydrology in the basin. Water from the river is diverted throughout the valley through a system of canals and ditches used for flood irrigation (Maurer and Berger, 2006). Infiltration from the streambed and ditches contributes to a shallow groundwater table that is less than 5-ft deep under much of the valley floor near the river (Maurer and Peltz, 1994).

The shallow aquifer in the valley consists of Quaternaryaged fluvial deposits, with thick, alluvial sand and gravel deposits along the valley margins (Maurer and Berger, 1986). The shallow aquifer is underlain by semi-consolidated Tertiary-age sediments and volcanic rocks in some places, with Jurassic to Cretaceous-aged metamorphic and granitic rocks making up the underlying basement bedrock. Depth to bedrock can be as great as 5,000 ft (Maurer, 1984). Confined conditions with artesian flow occur at depths of 200-300 ft in some areas (Maurer, 1986), but a valley-wide confining unit is not spatially persistent (Dillingham, 1980). Depth to groundwater ranges from less than $5 \mathrm{ft}$ below land surface near the Carson River to greater than $200 \mathrm{ft}$ in areas along the Carson and Pine Nut Mountains. Groundwater, predominantly originating from the Carson and Pine Nut Mountain ranges, flows toward the Carson River and then north along the river out of the basin (fig. 3). Primary sources of recharge are mountain block recharge, ephemeral and perennial drainages, the Carson River, and agricultural irrigation (Maurer and Berger, 2006). Yager and others (2013) hypothesize that a major north-south fault extending across the Tertiary-age sediments within the Carson Valley influences the regional groundwater-flow system.

\section{Data Collection and Analysis}

\section{Groundwater Sampling}

Groundwater samples were collected throughout Carson Valley to determine the spatial distribution of nitrate-N. Spatial analysis was performed to quantify the relationship between nitrate-N concentration and land use (fig. 4). A total of 173 different wells were sampled, and nitrate-N data collected by other agencies for 6 additional wells also were used in the analysis. In all, 228 groundwater samples were taken from private domestic, public-supply, monitoring, and agricultural irrigation wells from around the valley using USGS field methods (U.S. Geological Survey, 2008a). All samples were collected as close to the wellhead as possible, generally before water entered the pressure tank, using the existing well-pump system. The well was pumped, and samples were collected after readings for specific conductance, $\mathrm{pH}$, temperature, turbidity, and dissolved-oxygen concentrations had become stable (Koterba and others, 1995). Groundwater samples were collected during two rounds of sampling: round 1 during the winter of 2008-09 and round 2 during the summer of 2009. For round 1, a total of 126 wells were sampled. To select wells, the percentages of each land-use class - single family residential, multifamily residential, vacant, industrial, commercial, rural (including agriculture), utilities, and unclassified-were calculated for Carson Valley. Wells were then randomly selected from the USGS National Water Information System (NWIS) database in an area-weighted distribution apportioned to the percentage of each land-use class. For example, the determination of 50 percent rural land use would require that 50 percent of the wells had to be sampled from wells in the rural land-use class. This approach was not possible for every category because of an insufficient number of collocated wells, especially on vacant land. When permission to sample a randomly selected well could not be obtained, the next closest well in the same land-use class, where permission could be obtained, was sampled.

Wells selected for round 2 were based on the analytical results from round 1 and estimates of septic-system density. A total of 21 duplicate samples were collected in both rounds of sampling from wells where nitrate-N concentrations were greater than $3.5 \mathrm{mg} / \mathrm{L}$, and 81 samples were collected from areas where septic-system densities were greater than one septic system per 3 acres. A subset of wells, in both sampling rounds, was analyzed for chlorofluorocarbons (CFC), tritium, nitrogen and oxygen isotopes, and dissolved gasses.

\section{Sample Analysis}

An Orion 4-Star benchtop ion-specific electrode ISE/pH meter was used to analyze groundwater samples for nitrate-N and chloride. Chloride was analyzed to determine the relationship between nitrate-N contamination and septic-system density. If chloride increased with respect to nitrate-N, the source was assumed to have originated from septic systems. The accuracy of the meter for each sensor is \pm 2 percent, and the detection limit is $0.05 \mathrm{mg} / \mathrm{L}$ for nitrate- $\mathrm{N}$ and $0.3 \mathrm{mg} / \mathrm{L}$ for chloride.

A total of 36 samples were sent to the USGS National Water Quality Laboratory (NWQL) in Denver, Colorado, to verify the accuracy of the ISE. The results of this comparison indicated that nitrate- $\mathrm{N}$ and chloride concentrations measured with the ISE were consistently greater than concentrations reported by the NWQL.

A total of 30 dissolved-gas samples - methane, carbon dioxide, nitrogen, dissolved oxygen, and argon - were collected to provide supporting data to determine whether there had been any reduction in nitrate-N concentration due to denitrification. Under denitrifying conditions, groundwater nitrate- $\mathrm{N}$ and dissolved-oxygen concentrations would be 


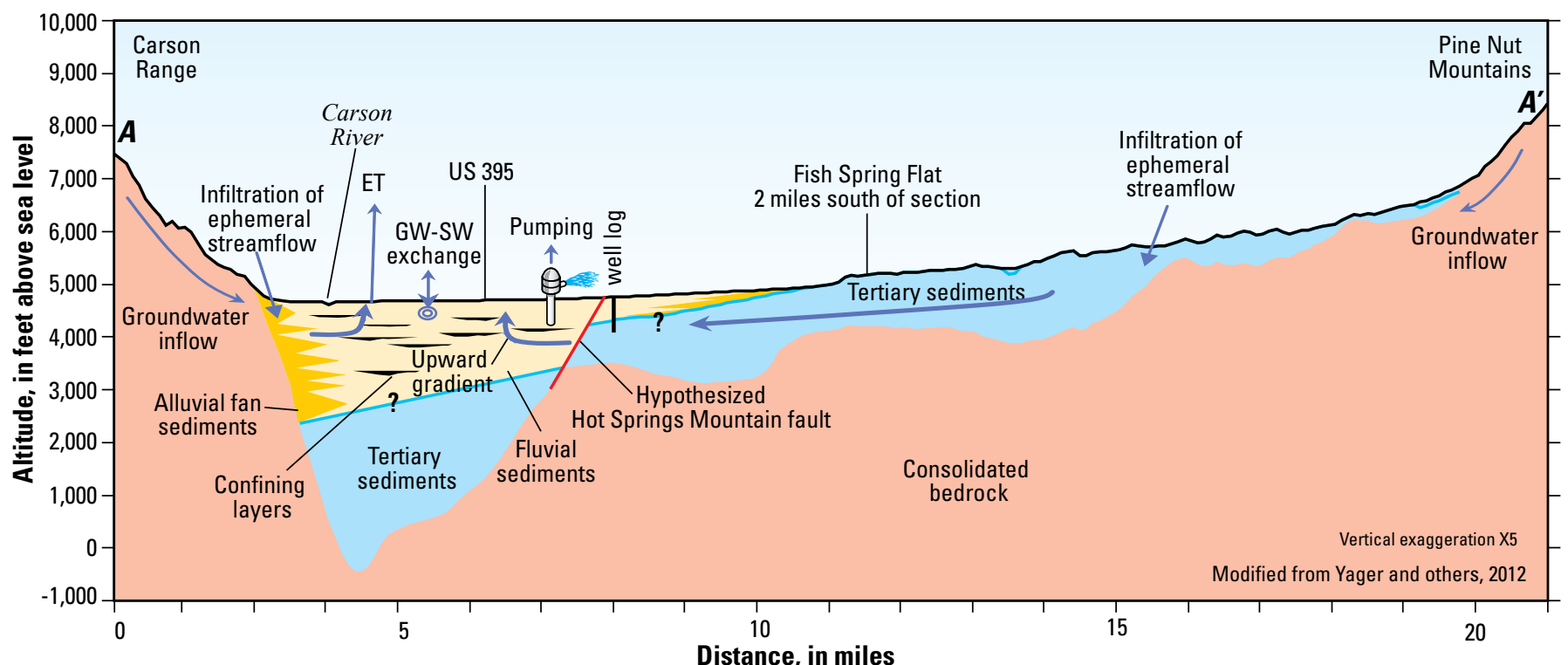

Figure 3. Geologic cross-section of Carson Valley, Nevada, shown from transect $A$ in figure 1 .

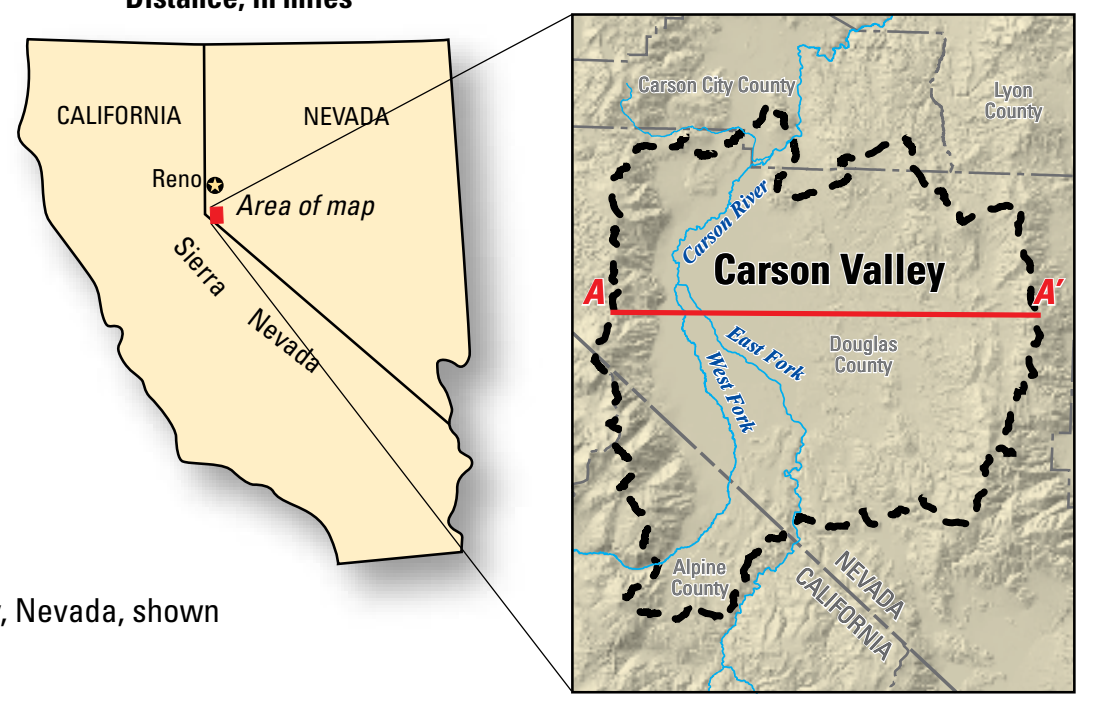

expected to be low, and anaerobic bacteria that use the oxygen in the nitrate for energy generate nitrogen gas as waste. Gas samples were collected based on USGS collection methods (U.S. Geological Survey, 2008b) and were analyzed at the USGS Chlorofluorocarbon Laboratory in Reston, Virginia.

A total of 37 groundwater samples were collected for nitrogen $\left(\delta^{15} \mathrm{~N}\right)$ and oxygen $\left(\delta^{18} \mathrm{O}\right)$ isotope analysis to determine the source of nitrogen in the groundwater. Samples were collected using the methods developed by Révész and Casciotti (2007). Samples were sent to the USGS Stable Isotope Laboratory in Reston, Virginia, for analysis using the bacterial conversion of nitrate- $\mathrm{N}$ to nitrous oxide method. Concentrations were measured on a continuous flow isotope ratio spectrometer (Silva and others, 2000; Sigman and others, 2001) and were reported as delta $(\delta)$ ratios in per mil (\%o) relative to nitrogen gas air for nitrogen and Vienna Standard Mean Ocean Water for oxygen.

A total of 30 groundwater samples were collected and analyzed for CFCs and tritium to determine the apparent age of the groundwater. Groundwater apparent age is defined as the length of time that has passed between recharge and sampling. It is determined by CFC and tritium, and incorporates a mixture of groundwater from different source areas. Samples were collected using standard USGS methods (U.S. Geological Survey, 2008a) and sent to the USGS Chlorofluorocarbon Laboratory in Reston, Virginia, for analysis of CFC-11, CFC-12, and CFC-113 concentrations. Samples were analyzed by using a purge-and-trap gas chromatography procedure with an electron-capture detector (U.S. Geological Survey, 2008a). Apparent ages calculated from CFC-11, CFC-12, and CFC-113 for this study showed agreement between each CFC measured and generally were within about 5 years of each other (appendix 2). Concentrations of the dissolved gases argon and neon were used to constrain recharge temperatures needed for the age determinations, which varied between 4 to 15 degrees Celsius. Most of the apparent groundwater recharged between 1970 and 1990, a period for which the recharge temperature does not change the apparent CFC ages in Carson Valley by more than 2 years (Hinkle and others, 2010). A total of 37 tritium samples were collected and sent 


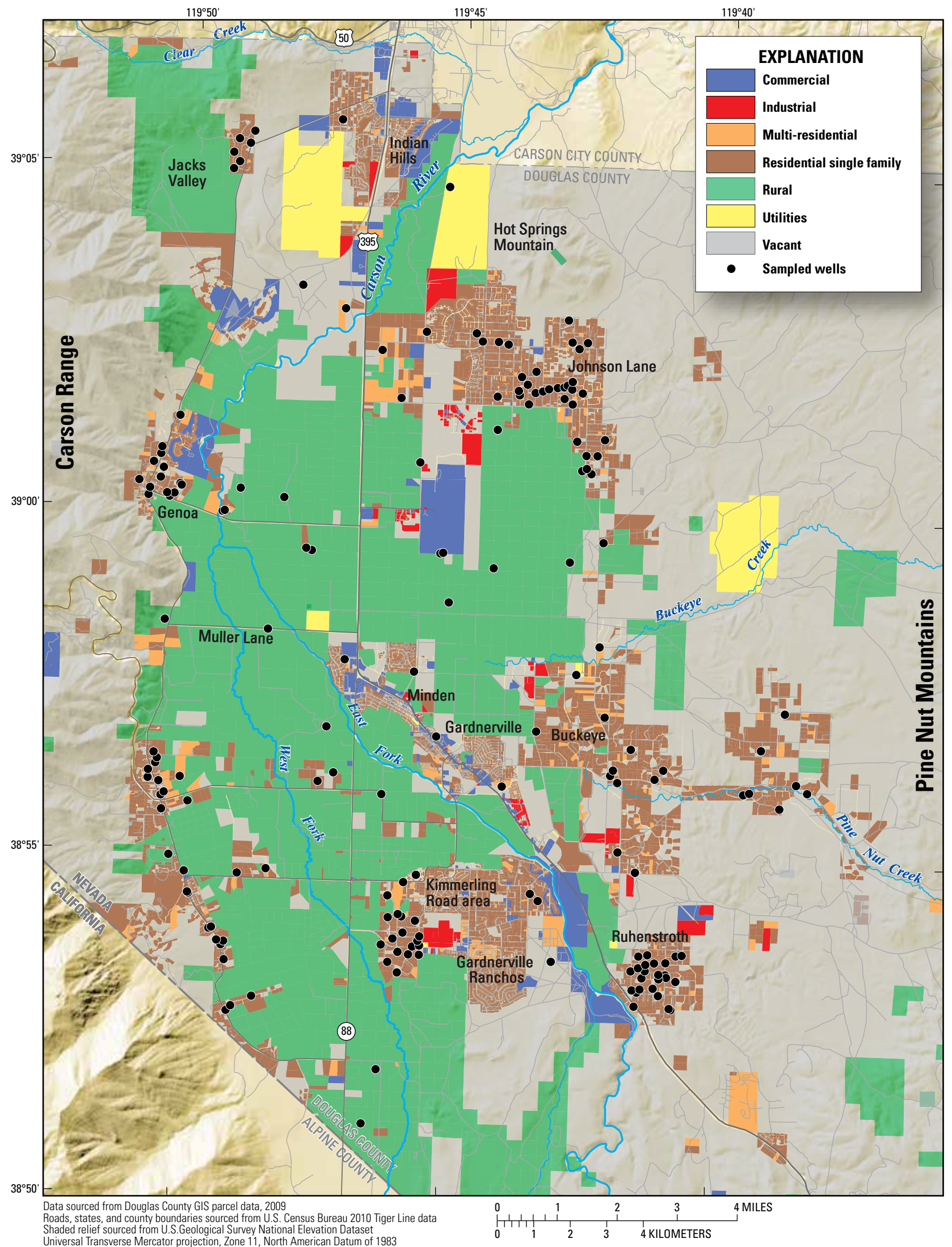

Figure 4. Spatial distribution of land use and sampled wells, Douglas county, Nevada, 2008. 
to the University of Miami Tritium Laboratory in Miami, Florida, for analysis by using low-level gas proportional counting (University of Miami, 2009). The tritium values were used to verify the CFC-age determinations. Tritium values that were below detection ( 0.05 tritium units) were considered to be older than atmospheric nuclear bomb testing, which sent large amounts of tritium into the atmosphere beginning around 1953. Tritium values greater than detection were considered to be either younger than 1953 or a mixture of water that was both younger and older than 1953.

\section{Quality Assurance}

Replicate samples were taken during both rounds of sampling for all constituents. During round 1, replicate samples were collected at 7 percent of the sites for nitrate- $\mathrm{N}$ and chloride and at 10 percent of the sites for CFC, tritium, dissolved gas, and nitrogen and oxygen isotopes. During round 2, replicate samples were collected at 10 percent of the sites for all analyses. Analytical results for all replicate samples were within 9 percent of the original measurement result. Nitrate$\mathrm{N}$ concentrations less than 0.05 milligrams per liter noted in the report refer to concentrations that were below the method detection limit.

For round 2, laboratory blanks were analyzed using the ISE. All results for the laboratory blanks were below detection for each probe. Three sample spikes were analyzed during round 2 for nitrate-N and chloride. Recovery for nitrate- $\mathrm{N}$ and chloride was \pm 4 percent of the added amount (table 1). Standards used to calibrate the nitrate-N and chloride ISE probes were sent to the USGS NWQL for analysis at different dilutions. Results for nitrate-N were within -9 percent of the measured concentration at low concentrations and within \pm 2 percent at concentrations greater than $2 \mathrm{mg} / \mathrm{L}$ (table 1). Chloride concentrations at all dilutions were all within 7 percent of the measured concentration (table 1).

\section{Land-Use Analysis}

Nitrate-N concentrations were compared to septic-system density and land use. Land-use classes were based on previously established designations from the Douglas County parcel database (fig. 4) and include residential single-family, residential multifamily, vacant, rural (including agricultural), commercial, industrial, and utilities (Douglas County, 2009). Areas not classified by the Douglas County parcel database were given a land-use class of unclassified. The date the septic systems were permitted on each parcel was included in the database. The percentage of land-use class, number of septic systems, and number of wells were calculated for a 1,640-ft (500-meter) buffer area around each sampled well. This method evaluates the contribution of local land uses and the effect on groundwater quality at a particular well (Koterba and others, 1995). This method of analysis is the same that was used in a previous land-use study of Carson Valley that was based on a smaller number of wells (Shipley and Rosen, 2005).

Table 1. Quality-assurance data collected for this study.

[Results from NWQL for ISE standards used during calibration. ISE, ion specific electrode; mg/L, milligrams per liter; NWQL, National Water Quality Laboratory]

\begin{tabular}{|c|c|c|c|c|c|c|}
\hline \multicolumn{7}{|c|}{ Results from ISE lab spikes for nitrate, chloride and bromide. } \\
\hline \multirow{2}{*}{$\begin{array}{l}\text { U.S. Geological Surey } \\
\text { site identification }\end{array}$} & \multicolumn{3}{|c|}{ Original measurment } & \multicolumn{3}{|c|}{ Original concentration of sample + spike added } \\
\hline & Nitrate (mg/L) & Chloride (mg/L) & Bromide (mg/L) & Nitrate + $2 \mathrm{mg} / \mathrm{L}$ & Chloride $+3 \mathrm{mg} / \mathrm{L}$ & Bromide $+0.1 \mathrm{mg} / \mathrm{L}$ \\
\hline 385654119431801 & 2.33 & 14.32 & 0.06 & 4.25 & 17.23 & 0.14 \\
\hline 385408119454401 & 4.67 & 7.18 & 0.19 & 6.65 & 10.15 & 0.3 \\
\hline USGS Site ID & Nitrate (mg/L) & Chloride (mg/L) & Bromide (mg/L) & & & \\
\hline 385340119403601 & 1.99 & 3.05 & 0.09 & & & \\
\hline 385654119431801 & 1.92 & 2.91 & 0.08 & & & \\
\hline 385408119454401 & 1.98 & 2.97 & 0.11 & & & \\
\hline 1 & 0.964 & 3.6 & & 5 & 4.765 & 4.7 \\
\hline 2 & 2.18 & -9 & & 10 & 9.755 & 2.45 \\
\hline 5 & 5.07 & -1.4 & & 20 & 18.773 & 6.135 \\
\hline 10 & 9.85 & 1.5 & & 100 & 99.814 & 0.186 \\
\hline 100 & 99.8 & 0.2 & & & & \\
\hline
\end{tabular}




\section{Nitrate-N Observations in Groundwater}

Out of 228 samples, 2 had a nitrate-N concentration that exceeded the MCL of $10 \mathrm{mg} / \mathrm{L}$, and 6 samples had concentrations less than $0.05 \mathrm{mg} / \mathrm{L}$ (fig. 5). Nitrate-N concentrations for the valley as a whole ranged from below detection to $18.3 \mathrm{mg} / \mathrm{L}$, with a mean concentration of $2.2 \mathrm{mg} / \mathrm{L}$ and median of $1.2 \mathrm{mg} / \mathrm{L}$ (appendix 1).

Chloride concentrations ranged from below detection (less than $0.3 \mathrm{mg} / \mathrm{L}$ ) to $238 \mathrm{mg} / \mathrm{L}$, with a mean of $12.2 \mathrm{mg} / \mathrm{L}$ and a median of $8.0 \mathrm{mg} / \mathrm{L}$. All results except for one were less than $70 \mathrm{mg} / \mathrm{L}$, well below the secondary U.S. EPA drinking water MCL of $250 \mathrm{mg} / \mathrm{L}$. Specific conductance, which is related to total dissolved solids, ranged from 42 to $3,220 \mu \mathrm{S} / \mathrm{cm}$, with a mean of $257 \mu \mathrm{S} / \mathrm{cm}$ and a median of $210 \mu \mathrm{S} / \mathrm{cm}$ (appendix 1). High dissolved oxygen concentrations (greater than $4.0 \mathrm{mg} / \mathrm{L}$ ) and low excess nitrogen gas production indicated that denitrification was not a major process controlling the attenuation of nitrate-N concentrations in groundwater (appendix 1).

The nitrate-N concentrations were plotted against dissolved oxygen (fig. $6 A$ ), chloride (fig. $6 B$ ), depth to the top of screened interval below land surface (fig. $6 C$ ), and specific conductance values (fig. $6 D$ ). One high value for specific conductance and chloride was not included in the regression. The correlation between these variables and nitrate- $\mathrm{N}$ improved during round 2 , which focused on wells that contained elevated concentrations of nitrate and were in single-family residential areas. A positive correlation was found between nitrate-N and both chloride and specific conductance, which is a proxy for total dissolved solids (fig. $6 B$ and $6 D$ ). Nitrate-N concentrations in shallow wells were greater than in deeper wells (fig. $6 C$ ). In both sampling events, there was a cluster of wells screened between 75 and 150 feet from land surface that had nitrate-N concentrations greater than $3 \mathrm{mg} / \mathrm{L}$.

A positive correlation exists between nitrate- $\mathrm{N}$ concentrations and the percentage of the residential single-family land use (table 2) for all data. A negative correlation for nitrate-N concentrations in rural and vacant land use indicated that concentrations of nitrate- $\mathrm{N}$ on groundwater were lower with less development. The median groundwater nitrate$\mathrm{N}$ concentration correlated with percentage of residential single-family land use (fig. 7A). The median nitrate-N concentration for residential multifamily, rural, and vacant land uses decreased slightly and was less variable with increased

Table 2. Correlation coefficients for select land-use and waterquality parameters.

\begin{tabular}{lcccc}
\hline \multicolumn{1}{c}{ Land use } & Nitrate & $\begin{array}{c}\text { Dissolved } \\
\text { oxygen }\end{array}$ & Chloride & $\begin{array}{c}\text { Specific } \\
\text { conductance }\end{array}$ \\
\hline Residential single family & 0.43 & 0.14 & -0.08 & -0.10 \\
Residential multifamily & -0.14 & -0.05 & -0.12 & -0.12 \\
Rural & -0.24 & -0.16 & -0.06 & -0.03 \\
Vacant land & -0.25 & 0.10 & -0.07 & -0.09 \\
\hline
\end{tabular}

land-use percentages (fig. $7 B, 7 C$, and $7 D$ ). The mean nitrate$\mathrm{N}$ concentration for wells in areas with greater than 50-percent single-family land use was $2.87 \mathrm{mg} / \mathrm{L}$, which is twice as high as in wells with less than 50-percent residential single-family land use $(1.31 \mathrm{mg} / \mathrm{L})$. The lower nitrate-N concentrations with increasing percent of multifamily residential, rural, and vacant land together indicates the influence of adjacent developed land.

\section{Nitrate-N Trends in Groundwater}

Rosen (2003) and Shipley and Rosen (2005) performed trend analyses using the nonparametric Kendall's tau statistic with a Sen slope estimate (Lorenz and others, 2011) on 27 long-term monitoring wells in Carson Valley. Since these studies were completed, 19 of these wells are still being monitored in the valley, and some have been sampled since 1985 for nitrate-N and total dissolved-solids concentrations. In 2005, however, 1of the 19 wells that was still being monitored was deepened, and subsequent concentrations of nitrate- $\mathrm{N}$ and total dissolved solids were lower, so it was not included in the analysis. In order to assess whether concentrations of nitrate- $\mathrm{N}$ and total dissolved-solids concentrations changed over time, and whether the changes observed in the previous studies are consistent with recent data, the same Kendall's tau test was used to test for trends in nitrate-N and total dissolved solids for these wells (table 3; see Shipley and Rosen, 2005, for details of the tests performed). With this test, a $p$-value less than 0.05 represents a statistically significant monotonic trend at the 95-percent confidence limit. Positive tau values indicate increasing trends, and negative tau values indicate decreasing trends.

Analysis from 12 of the 18 wells (67 percent) revealed statistically significant increasing trends for nitrate-N (table 3 ). Only one well had a decreasing trend for nitrate-N, and the results for five wells ( 28 percent) indicated stable concentrations with no apparent trend. Analysis from 11 of the 18 wells (61 percent) indicated that concentrations of total dissolved solids also were increasing significantly $(p<0.05)$. Only one well had a decreasing trend, and the results for six wells indicated stable concentrations of total dissolved solids with no apparent trend (table 3).

There were changes in trends for five individual wells compared to the Shipley and Rosen (2005) study for both nitrate-N and total dissolved solids. In one well, increasing trends for both nitrate-N and dissolved solids changed to decreasing trends. In the five other wells, either nitrate- $\mathrm{N}$ or total dissolved solids changed from decreasing to stable or stable to increasing trends.

Overall, the percentage of wells with increasing concentrations in nitrate-N and total dissolved solids trends was similar to Rosen (2003; methods and results presented in Shipley and Rosen, 2005). In Rosen (2003), 58 percent of the wells had an 


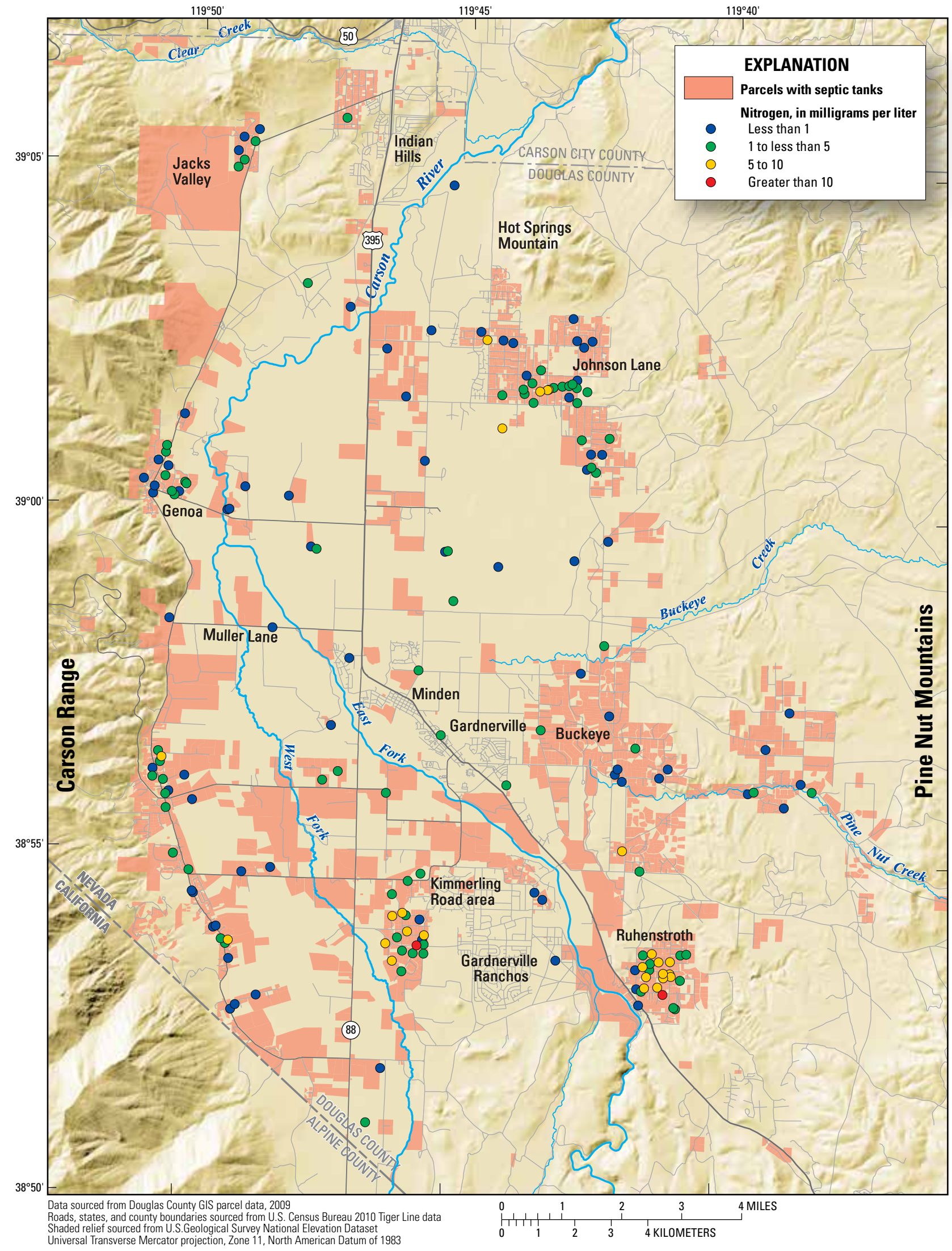

Figure 5. Nitrate as nitrogen concentrations in milligrams per liter in sampled wells and parcels with septic systems in Carson Valley, Douglas County, Nevada, 2008-09. 

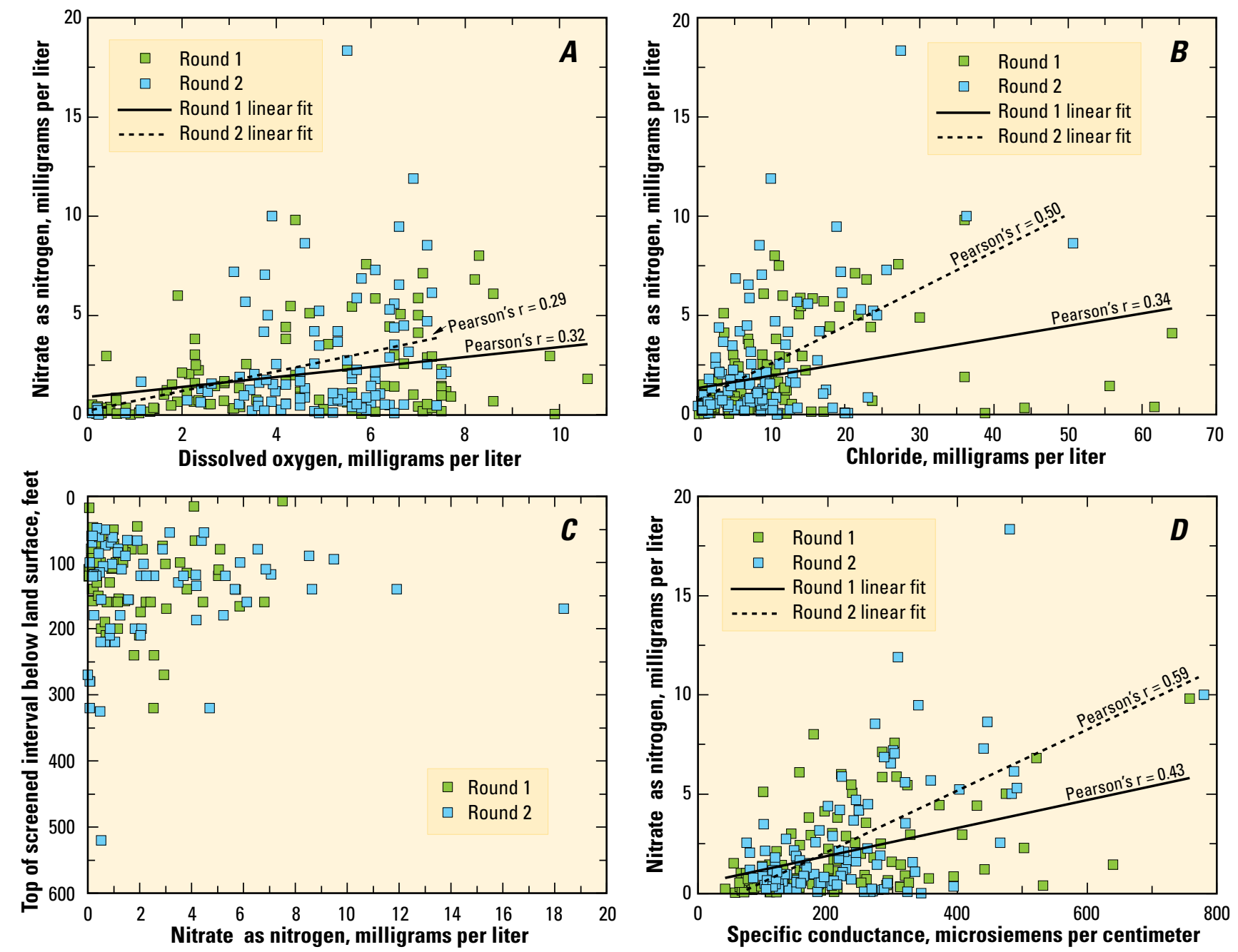

Figure 6. Geochemical results for sampled wells for the 2008-09 sampling events. Nitrate compared to $A$, dissolved oxygen; $B$, chloride; $C$, screen depth; and $D$, specific conductance.

increasing trend for nitrate- $\mathrm{N}$, and 52 percent had an increasing trend for total dissolved solids, from the analysis of 27 wells in Carson Valley (table 3). These results indicated that increasing trends for nitrate-N and total dissolved solids were still persisting in the valley in the areas being monitored.

Nitrate-N concentrations measured in wells in Carson Valley from 1980-2010 were aggregated in 5-year intervals to evaluate the regional trends (fig. 8). During 1996-2000, there were more samples collected from single family residential land-use areas than during other periods, which accounts for the higher concentrations observed. Concentrations at the 50th percentile exhibited a two-fold increase, from 1 to $2.1 \mathrm{mg} / \mathrm{L}$, from 1980 through 2010. Concentrations at both the 75th percentile and the 95 th percentile exhibited a four-fold increase ( 1 to $4 \mathrm{mg} / \mathrm{L}$ and 2 to $9 \mathrm{mg} / \mathrm{L}$, respectively) during the same period of sampling. This indicated that the monitoring wells with greater nitrate- $\mathrm{N}$ concentrations were increasing at a slightly higher rate than others. 


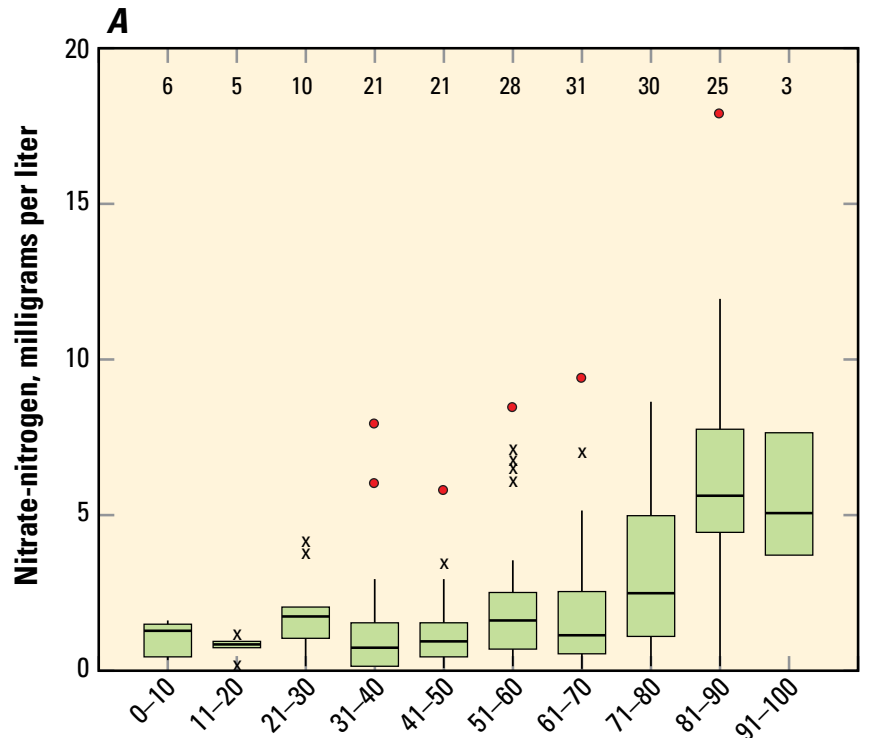

Percentage of single family residential land

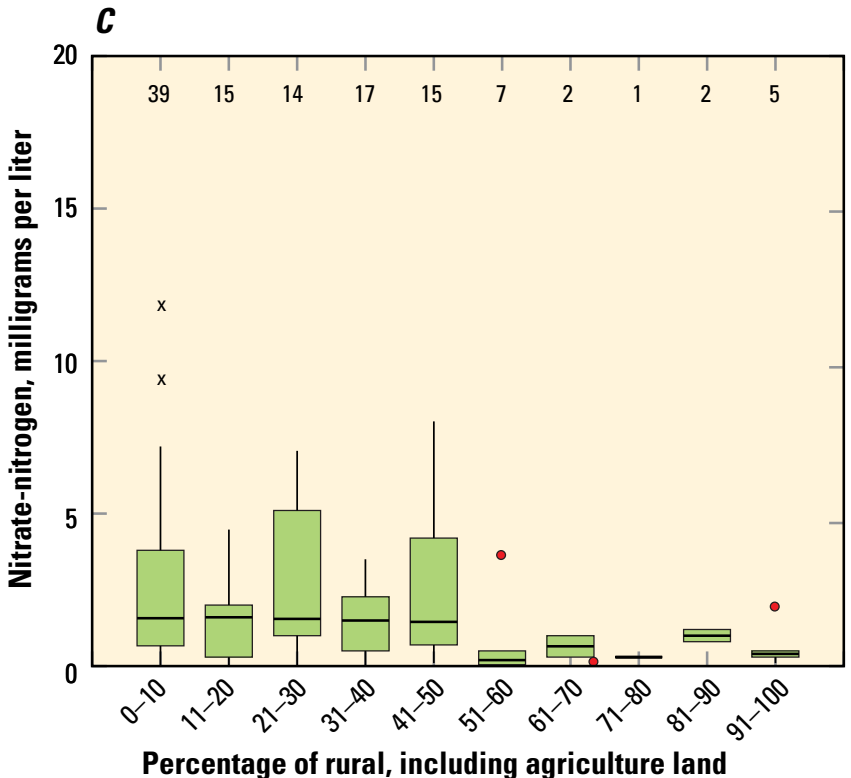

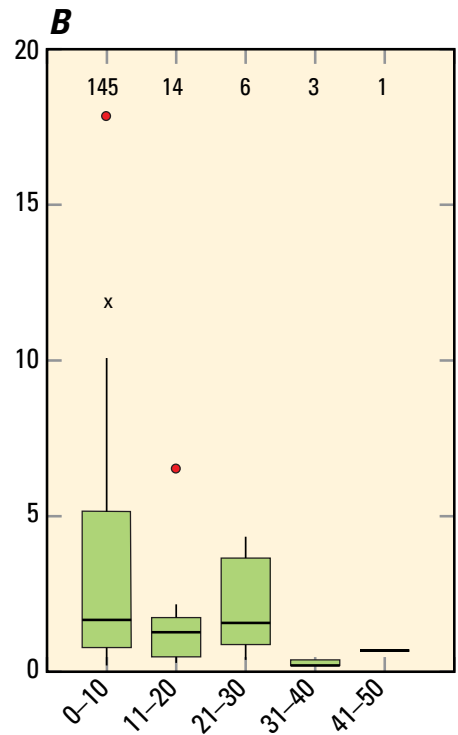

\section{EXPLANATION}

Schematic boxplot

30 Number of values

- Upper detached

$x$ Upper outside

T Upper adjacent

75th percentile

Median (50th percentile)

25th percentile

$\perp$ Lower adjacent

$x$ lower outside

- Lower detached

Values greater than zero were defined for the lower bounds of each category

\section{Percentage of multifamily residential land}

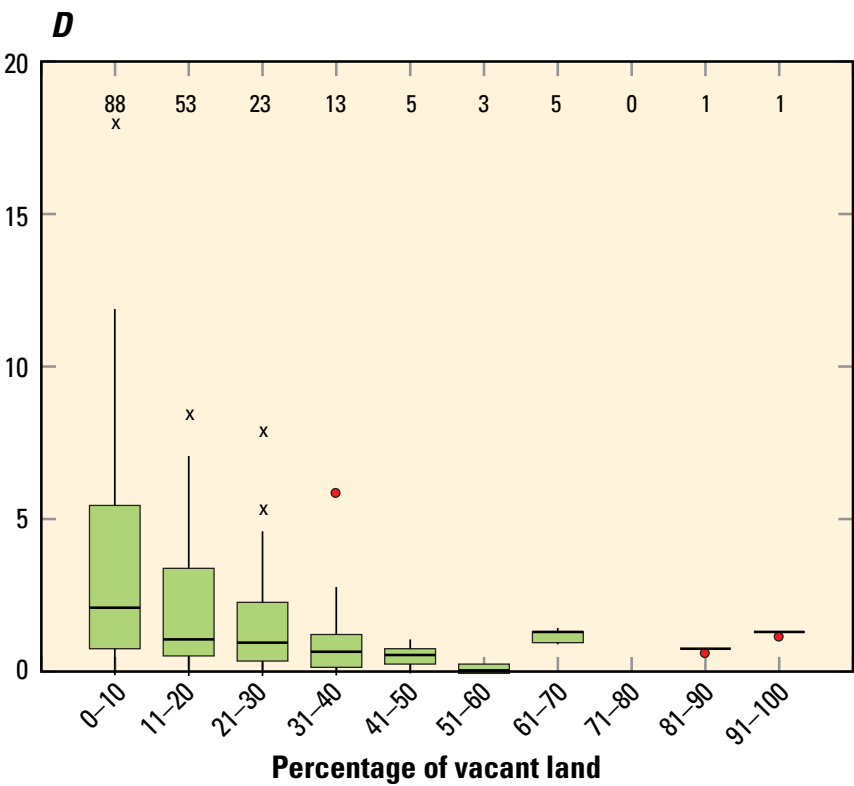

Figure 7. Range of nitrate as nitrogen concentrations relative to land-use and percentage of land use: $A$, single-family residential; $B$, residential multifamily; $C$, rural; and $D$, vacant land. 
Table 3. Kendall tau results for nitrate as nitrogen and total dissolved solids.

Abbreviation: N, number of samples in analysis; mg/L, milligrams per liter; I, indicates an increasing trend; S, indicates a stable trend; D, indicates a decreasing trend; <, less than; NR, no results; BDL, below detection limit; - , no data]

\begin{tabular}{|c|c|c|c|c|c|c|c|c|c|c|c|c|}
\hline \multicolumn{13}{|c|}{ Nitrate } \\
\hline Site identifier & $\begin{array}{c}\text { Well } \\
\text { number }\end{array}$ & \multicolumn{5}{|c|}{ Data to 2001 from Shipley and Rosen (2005) } & \multicolumn{6}{|c|}{ Includes all data through 2009} \\
\hline 385255119482301 & 1 & 22 & -0.35 & 0.02 & 0.1 & $\mathrm{~S}$ & 30 & -0.02 & 0.914 & 0.054 & $S$ & No \\
\hline 385300119405702 & 2 & 9 & 0.5 & 0.076 & 16.1 & I & 18 & -0.49 & 0.003 & 11.75 & $\mathrm{D}$ & Yes \\
\hline 385321119405002 & 3 & 20 & 0.31 & 0.054 & 2.9 & I & 28 & 0.64 & $<0.001$ & 3.1 & I & No \\
\hline 385352119455401 & 4 & 23 & 0.77 & 0 & 2 & I & 31 & 0.74 & $<0.001$ & 2.2 & I & No \\
\hline 385509119414801 & 7 & 22 & 0.59 & 0.001 & 1.1 & I & 32 & 0.75 & $<0.001$ & 1.35 & I & No \\
\hline 385604119435601 & 8 & 18 & 0.15 & 0.397 & 1.3 & $\mathrm{~S}$ & \multicolumn{6}{|c|}{ No new data. Last sample taken in 1997} \\
\hline 385654119431801 & 9 & 23 & 0.38 & 0.012 & 1.6 & I & 32 & 0.42 & $<0.001$ & 1.85 & I & No \\
\hline 385719119454701 & 10 & 16 & 0.36 & 0.058 & 0.4 & I & \multicolumn{6}{|c|}{ No new data. Last sample taken in 1997} \\
\hline 390017119453901 & 15 & 13 & NR & NR & $\mathrm{BDL}^{3}$ & $\mathrm{~S}$ & 16 & NR & NR & $\mathrm{BDL}^{3}$ & S & No \\
\hline 390017119455901 & 16 & 7 & NR & NR & $\mathrm{BDL}^{3}$ & $\mathrm{~S}$ & 12 & NR & NR & $\mathrm{BDL}^{3}$ & $\mathrm{~S}$ & No \\
\hline 390021119504301 & 17 & 19 & 0.18 & 0.307 & 0.2 & $\mathrm{~S}$ & 30 & 0.3 & 0.021 & 0.19 & I & Yes \\
\hline 390055119421901 & 18 & 21 & 0.58 & 0.001 & 0.87 & I & \multicolumn{6}{|c|}{ Well Deepened in 2005} \\
\hline 390106119424301 & 19 & 22 & 0.4 & 0.008 & 1.5 & I & 30 & 0.42 & $<0.001$ & 1.51 & I & No \\
\hline 390208119433201 & 20 & 43 & 0.72 & 0.001 & 1.5 & I & 57 & 0.75 & $<0.001$ & 2.1 & I & No \\
\hline 390230119480001 & 21 & 8 & -0.71 & 0.019 & 1 & $\mathrm{D}$ & 25 & -0.01 & 0.94 & 1.12 & S & Yes \\
\hline 390232119443201 & 22 & 41 & 0.84 & 0.001 & 2.8 & I & 54 & 0.87 & $<0.001$ & 3.25 & I & No \\
\hline 390446119451401 & 23 & 46 & NR & NR & $\mathrm{BDL}^{3}$ & $\mathrm{~S}$ & 60 & NR & NR & $\mathrm{BDL}^{3}$ & S & No \\
\hline 390457119491301 & 24 & 23 & 0.4 & 0.004 & 1 & I & 31 & 0.57 & $<0.001$ & 1.1 & I & No \\
\hline
\end{tabular}

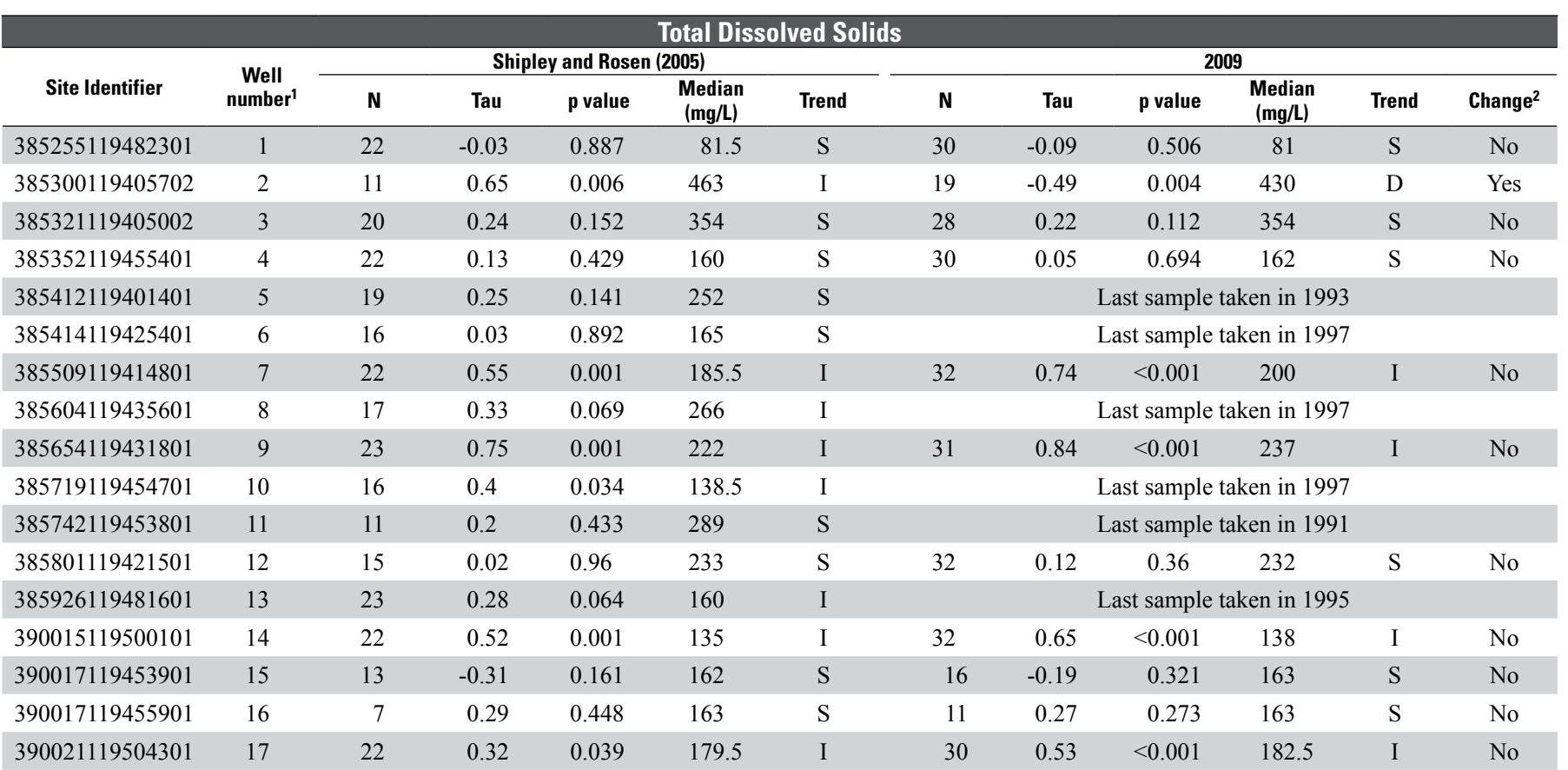


Table 3. Kendall tau results for Nitrate as nitrogen and total dissolved solids. - Continued

\begin{tabular}{|c|c|c|c|c|c|c|c|c|c|c|c|c|}
\hline \multicolumn{13}{|c|}{ Total Dissolved Solids } \\
\hline Site Identifier & $\begin{array}{c}\text { Well } \\
\text { number }\end{array}$ & \multicolumn{5}{|c|}{ Shipley and Rosen (2005) } & \multicolumn{6}{|c|}{2009} \\
\hline 390055119421901 & 18 & 21 & 0.5 & 0.002 & 273 & I & \multicolumn{6}{|c|}{ Well deepened in 2005} \\
\hline 390106119424301 & 19 & 22 & 0.39 & 0.013 & 272 & I & 30 & 0.5 & $<0.001$ & 274.5 & I & No \\
\hline 390208119433201 & 20 & 41 & 0.7 & 0.001 & 286 & I & 57 & 0.7 & $<0.001$ & 302 & I & No \\
\hline 390230119480001 & 21 & 10 & -0.18 & 0.53 & 389 & S & 25 & 0.41 & 0.004 & 421 & I & Yes \\
\hline 390457119491301 & 24 & 22 & 0.21 & 0.172 & 81 & S & 30 & 0.5 & $<0.001$ & 83 & I & Yes \\
\hline 390503119463501 & 25 & 18 & -0.31 & 0.081 & 161 & S & \multicolumn{6}{|c|}{ Last sample taken in 1997} \\
\hline 390542119472001 & 26 & 21 & 0.46 & 0.001 & 168 & I & 30 & 0.51 & $<0.001$ & 171 & I & No \\
\hline 390622119470301 & 27 & 6 & 0.6 & 0.133 & 502.5 & $\mathrm{~S}$ & \multicolumn{6}{|c|}{ Last sample taken in 1990} \\
\hline
\end{tabular}

${ }^{1}$ Well number refers to locations listed in Shipley and Rosen (2005).

2 "Yes" indicates a change in trend from Shipley and Rosen (2005) to 2009, and "No" indicates the same trend for Shipley and Rosen (2005) and 2009.

${ }^{3}$ Samples were below detection limit, so that no trend could be determined.

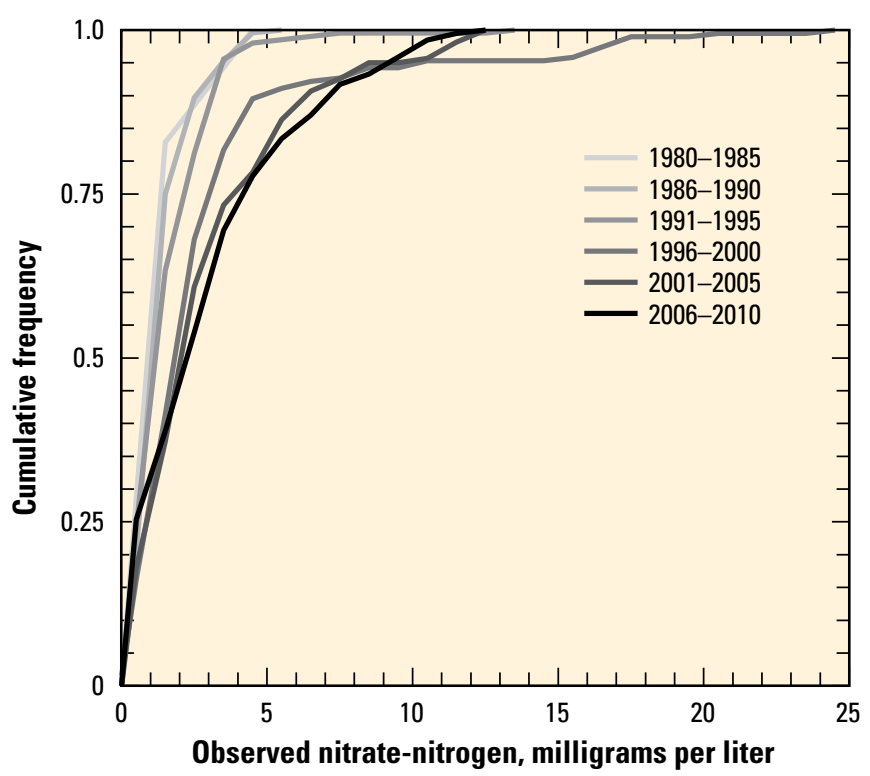

Figure 8. Cumulative frequency of observed nitrate as nitrogen concentrations for Carson Valley, Douglas County, Nevada 1980-2010.

\section{Nitrate-N Sources in Groundwater}

The stable isotopes of nitrogen and oxygen in the nitrate molecule can be used to determine sources of nitrate in the water sampled if denitrification processes are minor (Kendall, 1998). Different sources of nitrate have characteristic signatures of $\delta^{15} \mathrm{~N}$ and $\delta^{18} \mathrm{O}$. A scatterplot of $\delta^{15} \mathrm{~N}$ versus $\delta^{18} \mathrm{O}$ can indicate the source of nitrate and can also indicate if denitrification is important if the source cannot be determined (fig. $9 A$ ). $\delta^{15} \mathrm{~N}$ ranged from 3.15 to 20.13 per mil (\%), and $\delta^{18} \mathrm{O}$ ranged from -6.19 to $8.8 \%$ (appendix 2). A total of 34 of the 37 samples ( 92 percent) analyzed in this study were in the range of either natural soil $\mathrm{N}$ or manure and septic-wastederived nitrogen (fig. 9A). Three samples ( 8 percent) fell into only the manure and septic-waste range and were outside of the soil $\mathrm{N}$ range, but two of those samples were likely affected by denitrification, which is consistent with the low dissolved oxygen and high dissolved nitrogen gas observed for these samples. Samples with $\delta^{15} \mathrm{~N}$ values greater than $7 \%$ were located in areas with almost twice as many septic systems (82 septic systems) within 1,640 ft of the sampled well than samples less than 7\%o (42 septic systems). In addition, samples with $\delta^{15} \mathrm{~N}$ values greater than $7 \%$ had average nitrate-N concentrations two times greater than samples with less than $7 \%$.

Although most $\delta^{15} \mathrm{~N}$ values overlap between natural soil values and water affected by animal and human waste, if all of the $\delta^{15} \mathrm{~N}$ was derived from soil nitrate, a random pattern of values would be expected. Because $\delta^{15} \mathrm{~N}$ values with nitrate- $\mathrm{N}$ concentrations greater than $5 \mathrm{mg} / \mathrm{L}$ mostly (all but one measurement) plot very close to the boundary between soil $\mathrm{N}$ and 

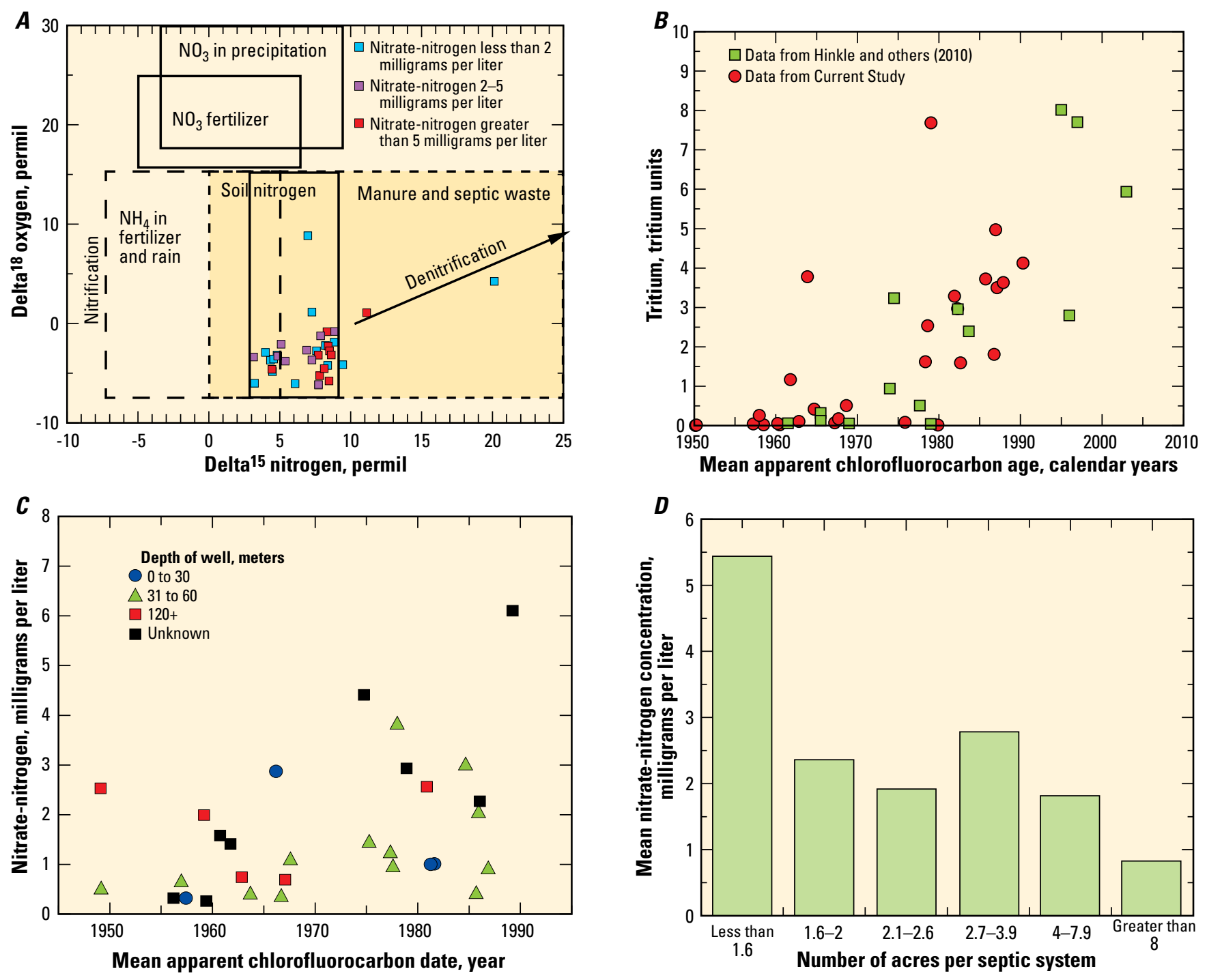

Figure 9. Geochemical results for wells sampled for $A$, nitrogen and oxygen isotopes of nitrate (boxes showing isotopic ranges of different nitrate as nitrogen sources are from Kendall, 1998); $B$, tritium; and $C$, chlorofluorocarbons; and $D$, mean nitrate concentrations associated with parcel size.

animal and human waste derived $\delta^{15} \mathrm{~N}$, it is likely that these $\delta^{15} \mathrm{~N}$ values were influenced by a mixture of soil $\mathrm{N}$ and animal and human derived sources. Although human and animal sources cannot be differentiated, these wells were all located in areas where single family dwellings were the main land use around the well. Thus, septic systems are likely to be the cause for elevated $\delta^{15} \mathrm{~N}$ values in these wells. These results are consistent with nitrogen isotopic studies of groundwater from the Indian Hills area in Carson Valley (Thomas and others, 1999), which determined that elevated nitrate- $\mathrm{N}$ concentrations in groundwater were due to leaching from septic systems.

\section{Apparent Groundwater Age}

There was agreement between $\mathrm{CFC}$ and tritium apparent ages calculated for this study and in other recent work in Nevada (fig. 9B; Hinkle and others, 2010). The groundwater age-dating results from this study indicated that the relatively recently recharged water contains greater concentrations of nitrate- $\mathrm{N}$ than older water. The mean groundwater apparent time of recharge, determined from CFC results, ranged from 1950 to 1990 , with a median of 1972 and a standard deviation of 12 years (fig. 9C). In general, nitrate- $\mathrm{N}$ concentrations are elevated in water that is less than 30 years old. Tritium concentrations ranged from below detection (less than 0.30) to 24.74 picocuries per liter $(\mathrm{pCi} / \mathrm{L})$, with a mean concentration of $8.11 \mathrm{pCi} / \mathrm{L}$ and a median of $6.99 \mathrm{pCi} / \mathrm{L}$ (appendix 3 ). 
The apparent ages of water in the aquifer, calculated from CFC and tritium, were generally between 20 and 40 years and were older than those calculated from the numerical model (see later). The differences in estimated age can be attributed to representing the mean chemical age of water as a mixture of water traveling from recharge areas in the mountains (long flow paths) outside of the model boundaries with water recharged from septic tanks and irrigation drainage (short flow paths). Simulated arrival times from the unsaturated-zone model accounted for only the discharge of septic effluent and not the mixing of water from the aquifer. Therefore, the apparent ages and the simulated arrival times were only an estimate of different mixtures of water and probably do not reflect the actual age of water in the aquifer.

The mean nitrate- $\mathrm{N}$ concentration for wells with high septic system densities (less than 1.6 acres per septic system) within the buffer area was $5.5 \mathrm{mg} / \mathrm{L}$ (fig. $9 D$ ), which is twice as much as for wells with lower septic system densities (greater than 1.6 acres per septic system). The amount of time a septic system has been in use also could be related to nitrate-N concentrations. Some areas around the valley have high septicsystem densities, but low overall nitrate-N concentrations (less than $1.0 \mathrm{mg} / \mathrm{L}$ ) that could be attributed to the age of the septic system.

\section{Nitrogen-N Contribution from Septic Systems}

A schematic diagram shows infiltration and nitrogen loading by septic systems with leach fields (called septic systems, herein), domestic pumping represented by the flow and transport models, as well as denitrification reactions in groundwater (fig. 10). Nitrogen in raw wastewater is primarily in the form of organic matter, which is converted to ammonia (U.S. Environmental Protection Agency, 2002). Once effluent discharge enters the unsaturated zone, aerobic bacteria convert the ammonia in the effluent almost entirely to nitrite and then to nitrate. Thus, the source of nitrate-N to groundwater is the oxidation of ammonia, or urea, in the unsaturated zone from the septic systems. The concentration of nitrate- $\mathrm{N}$ in groundwater is highly dependent on other factors, such as adsorption, volatilization, mineralization, nitrification, and denitrification (Cantor and Knox, 1985; U.S. Environmental Protection Agency, 2002). Wastewater effluent contains 35-100 mg/L of total nitrogen that can be readily converted to nitrate-N in aerobic unsaturated-zone conditions (U.S. Environmental Protection Agency, 1980; U.S. Environmental Protection Agency, 2002). Groundwater withdrawal by domestic, agricultural, or

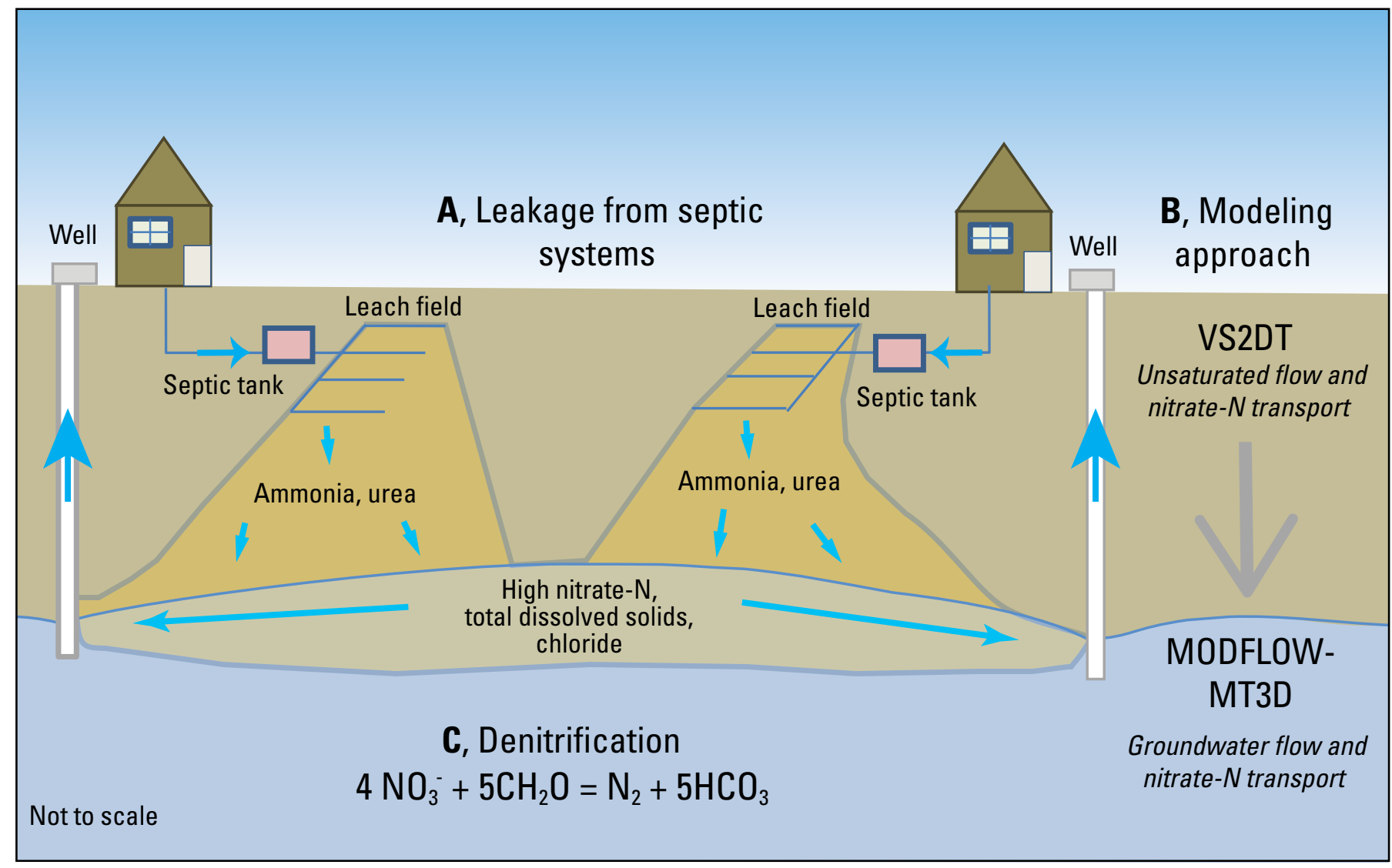

Figure 10. Schematic diagram representing $A$, sources of nitrate as nitrogen (N) from septic systems as a result of oxidation of ammonia or urea leaching to groundwater and removal from domestic pumping; $B$, modeling approach for simulating nitrate- $N$ transport in the unsaturated and saturated zones; and $C$, the stoichiometry for the denitrification process $\left(\mathrm{CH}_{2} \mathrm{O}\right.$ represents organic matter; $\mathrm{N}_{2}$ represents nitrogen gas; $\mathrm{NO}_{3}^{-}$represents nitrate). 
municipal pumping can affect the transport of the nitrate- $\mathrm{N}$ by controlling the groundwater-flow gradient and removing mass. Likewise, nitrate-N can become concentrated in groundwater if the rate of discharge from septic systems increases or groundwater flow is reduced as a result of low permeability aquifer materials. In anaerobic environments, denitrification can remove nitrate- $\mathrm{N}$ when an electron donor, such as carbon, is present, but this process usually occurs in the saturated zone and produces nitrogen gas. For the interpretation of the water-quality data, the criteria used for identifying whether denitrification is occurring are low dissolved oxygen and the production of nitrogen gas in groundwater samples.

Important variables for estimating nitrate-N mass loading to the aquifer are the rate and nitrogen concentration of the effluent and the septic-system density. The average annual volume of septic-system recharge to aquifers assumed was 7,769 acre-feet per year (acre-ft/yr), or about 220,018 liters per household (State of Nevada, 2009; Yager and others, 2012). Assuming the contribution of nitrate-N in septic-tank effluent is $40 \mathrm{mg} / \mathrm{L}$, which is in the range of similar assessments of nitrate-N contamination resulting from septic tank systems (Zhan and Mackay, 1998; Rosen and others, 2006), the annual mass contribution for each household would be approximately $8.8 \times 10^{6} \mathrm{mg}$. These findings are similar to the estimates of nitrate-N mass loading in alluvial aquifers in Spanish Springs, Nevada. (Rosen and others, 2006) and New Washoe City, Nevada, (Zhan and Mackay, 1998). In 2009, the total number of septic tanks for Johnson Lane and Ruhenstroth is 1933, and the annual contribution for both areas is $1.7 \times 10^{10} \mathrm{mg}$ or approximately 17 metric tons. Considering the estimated arrival time of nitrate- $\mathrm{N}$ to the aquifer for the Johnson Lane and Ruhenstroth areas, the total contribution of nitrate- $\mathrm{N}$ from 1970-2009 is 303 and 86 metric tons, respectively. These estimates of mass of nitrate- $\mathrm{N}$ reflect gross assumptions of the volumetric rate of annual septic-tank infiltration and source concentration that were not measured in this study. Further, the effluent that flows from the septic-tank systems will contain other forms of nitrogen (urea, ammonium, organic nitrogen), and biochemical transformations that create or remove nitrate-N were also not accounted for in these calculations. These calculations, however, provide a conservative estimate of the total contribution of nitrogen- $\mathrm{N}$ to the alluvial aquifer for the two areas in Douglas County. The density of septic systems can also affect the ability of the aquifer to dilute the effluent concentration, and high densities can result in increasing concentrations over time. Shipley and Rosen (2005) reported that septicsystem densities of one per 3 acres are associated with stable concentrations in the aquifer. As shown in fig. $9 D$, the greatest effects on the aquifer resulted from high septic densities, or, inversely, the greater the parcel size the lower the effects. The minimum critical density (acreage per developed parcel) to ensure nitrate- $\mathrm{N}$ concentrations below the EPA
MCL of $10 \mathrm{mg} / \mathrm{L}$ nitrate-N can be calculated from the following (Hantzche and Finnemore, 2005):

$$
\mathrm{Dc}=(2.01 \times(\mathrm{Np}-10)) /(\mathrm{Dp} \times(10-\mathrm{Nb}))
$$

where

Dc is the critical density (acres/dwelling),

$\mathrm{Np}$ is the effluent nitrate- $\mathrm{N}$ concentration in $\mathrm{mg} / \mathrm{L}$,

$\mathrm{Nb}$ is the background nitrate- $\mathrm{N}$ concentration of rainfall in $\mathrm{mg} / \mathrm{L}$,

Dp is deep percolation of rainfall (recharge rate) in in/yr, and

2.01 is a conversion factor for assumption of the discharge rate of 150 gallons per day per dwelling. For example, for a background concentration of $0.1 \mathrm{mg} / \mathrm{L}$, a recharge rate of $0.4 \mathrm{in} / \mathrm{yr}$ (approximate recharge rate for Douglas County), and an effluent concentration of $40 \mathrm{mg} / \mathrm{L}$, approximately 15 acres per dwelling unit, would be needed to avoid exceeding the MCL of $10 \mathrm{mg} / \mathrm{L}$ nitrate-N (fig. 11). Higher effluent concentrations $(100 \mathrm{mg} / \mathrm{L})$ that could result from an inefficient septic system would require a density of 44 acres per dwelling. Areas with higher recharge rates (from precipitation, irrigated agriculture, or landscape watering) require lower densities because effluent concentrations are diluted more. Conversely, areas where recharge rates are reduced by the construction of impervious areas through development require higher densities. Although this calculation does not consider the effects of the rate of groundwater flow or pumping on nitrate-N concentrations, it provides preliminary estimates of the nitrogen loading to the aquifer. Consequently, the calculation also indicates septic-system use in environments with low precipitation requires a significant buffer between septic leach fields or larger parcel sizes (greater than 10 acres-lots).

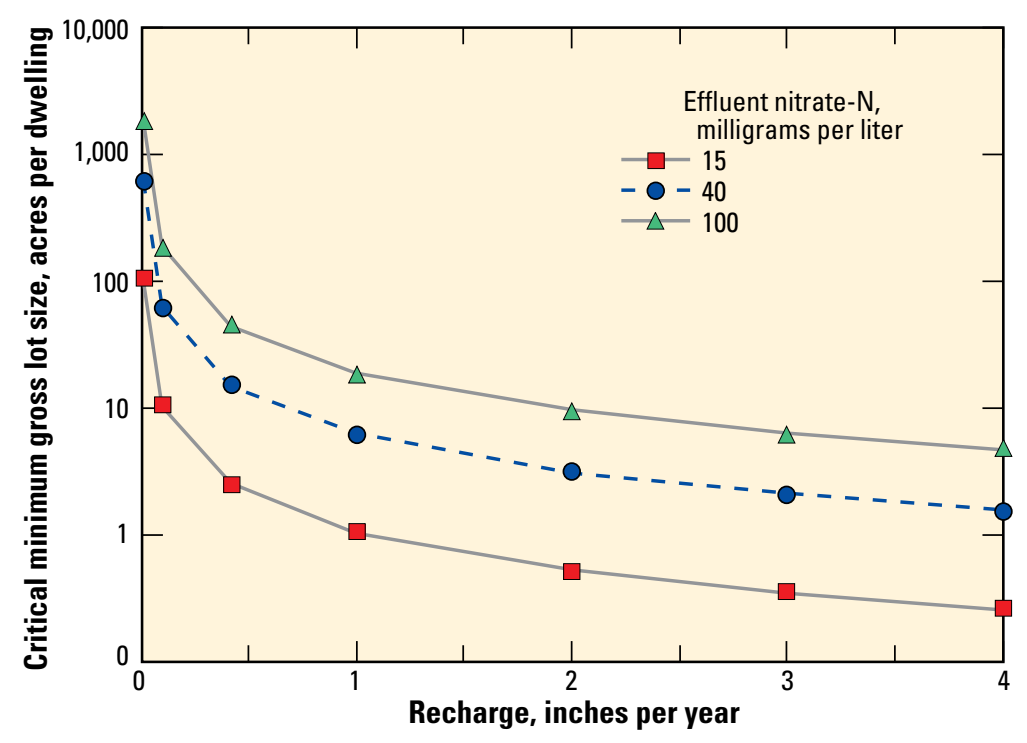

Figure 11. Septic-system densities required to maintain nitrate as nitrogen concentrations less than 10 milligrams per liter, as a function of effluent concentration, or $\mathrm{Np}$, in milligrams per liter, and recharge rate, in inches per year. 


\section{Numerical Transport Models}

The one-dimensional transport of nitrate-N from septic systems to the shallow aquifer through the unsaturated zone was simulated with VS2DT (Hsieh and others, 2000; Healy and Ronan, 1996), a program that simulates flow and solute transport through variably saturated porous media. Threedimensional transport of nitrate- $\mathrm{N}$ in the shallow aquifer was simulated by using the groundwater-flow model MODFLOW-2005 (Harbaugh, 2005) and transport model MT3DMS (Zheng and Wang, 1999) within the graphical user interface MODELMUSE (Winston, 2009). The transport of nitrate$\mathrm{N}$ was simulated from 1970 through 2009 and predicted to 2059, given the pumping from domestic wells and loading of nitrate- $\mathrm{N}$ to the aquifer from conditions extrapolated from 2009. The results of the current (2009) and predictive (2059) models served as a basis for comparison to two additional hypothetical transport scenarios: 1) H1 with discontinued use of septic systems in 2030 but allowing continued pumping from domestic supply wells, and 2) $\mathrm{H} 2$ with discontinued use of septic systems and termination of domestic well pumpage in 2030. Groundwater recharge and withdrawals from industrial, agricultural, and municipal use were assumed to remain constant during 2009-59.

\section{Groundwater Flow and Transport Model Design}

A transient, regional groundwater-flow model developed for the Carson Valley (Yager and others, 2013) was used as the basis for the transport model and hypothetical scenarios. The regional flow model was developed to predict potential effects of changes in water use and management for the valley and was calibrated to transient water-table elevations and discharge in the Carson River. MODFLOW and MT3D models were constructed for two areas of interest-Johnson Lane and Ruhenstroth (fig. 12)—where groundwater contains nitrate$\mathrm{N}$ concentrations greater than $3.5 \mathrm{mg} / \mathrm{L}$ and septic system densities are greater than one septic system per 3 acres. The timing and variation of nitrate- $\mathrm{N}$ concentrations in the shallow aquifer are dependent on the distance and arrival time from the septic-tank systems to the water table, the hydraulic properties, and the rate of septic discharge. The arrival time of nitrate-N loading through the unsaturated zone to the aquifer is hereby called the arrival time.

The transport models were used to predict the relative effects of changes to future septic-system usage and domestic pumping on nitrate- $\mathrm{N}$ concentrations in two developed areas within Carson Valley. The models are not intended to be exact replications of transport of nitrate- $\mathrm{N}$ in the shallow aquifer or to be used to project when concentrations at monitoring wells will exceed or not exceed the MCL because insufficient data are available to adequately describe the distribution and movement of nitrate- $\mathrm{N}$ in these areas. The models provide a reasonable approximation of transport, within the constraints and limitations of available data, and can be used to simulate the overall behavior of nitrate- $\mathrm{N}$ transport, given the future reduction of loading from septic-tank systems and domestic pumping stresses. A sensitivity analysis was used to quantify the effect of hydraulic and transport parameters on simulated nitrate-N concentrations in 2009.

\section{Nitrate-N Transport in the Unsaturated Zone}

Transport of nitrate-N through the unsaturated zone was determined by using a VS2DT model constructed to simulate leakage from a septic system to the shallow aquifer. The arrival time to the water table was estimated from VS2DT results and later used to account for the delay between the infiltration of nitrate- $\mathrm{N}$ in septic discharge and the arrival at the water table in the MODFLOW/MT3D models. The unsaturated zone was represented in the VS2DT model as homogeneous and isotropic media, so the soil properties did not vary with depth. A characteristic curve for soil that relates unsaturated hydraulic conductivity to the degree of saturation within VS2DT for a sandy loam and medium sand textures (Hsiesh and others, 2000), which represent low to moderate infiltration rates, was initially used to determine the range in arrival times to the aquifer. Based on initial simulations, a medium sand texture better represented the nitrate- $\mathrm{N}$ concentrations observed in the wells sampled in 2008-09. Therefore, the soil properties saturated hydraulic conductivity, porosity, and dispersivity were specified as 55 feet per hour (ft/hr), 0.375, and $32 \mathrm{ft}$, respectively, to represent medium sand texture in the unsaturated zone.

The model grid for the VS2DT simulation was specified with 1,000 rows that were each $0.32 \mathrm{ft}$ thick. The overall dimension of the model was $131 \mathrm{ft}$ by $328 \mathrm{ft}$; however, transport was assumed to be only in the vertical downward direction. The septic-system leach field was defined as an area of 1,200 square feet $\left(\mathrm{ft}^{2}\right)$, assuming a leach field of two $75-\mathrm{ft}$ trenches with an area of $16 \mathrm{ft}^{2}$ required for a 4-bedroom house and a 1,200-gallon septic tank, as specified in the Douglas County Building Division Septic Application (Douglas County, 2006). A constant flux of approximately $6.5 \mathrm{ft} / \mathrm{yr}$ (Maurer and Berger, 2006; Yager and others, 2012), which was the sum of natural recharge from precipitation $(0.035 \mathrm{ft} / \mathrm{yr})$ and leakage from the septic system $(6.47 \mathrm{ft} / \mathrm{yr})$, was applied at the top boundary. The septic-system leakage was assumed to contain nitrate- $\mathrm{N}$ at a concentration of $40 \mathrm{mg} / \mathrm{L}$ - the median nitrate- $N$ concentration $(n=96)$ obtained from lysimeter data beneath septic leach fields in Spanish Springs, Nevada, (Rosen and others, 2006). Initial concentration within the model was assumed to be $0.0 \mathrm{mg} / \mathrm{L}$, and the bottom boundary was represented as the water table with a specified pressured head of $0.0 \mathrm{ft}$.

Solute breakthrough curves were analyzed to determine the mean arrival time at various depths within the model boundary. Five grid cells, at depths of 24, 68, 162, 252, and 322-ft, were analyzed within the model domain to estimate the mean arrival time and to develop a regression equation to be applied to the Johnson Lane and Ruhenstroth areas (fig. 13). 


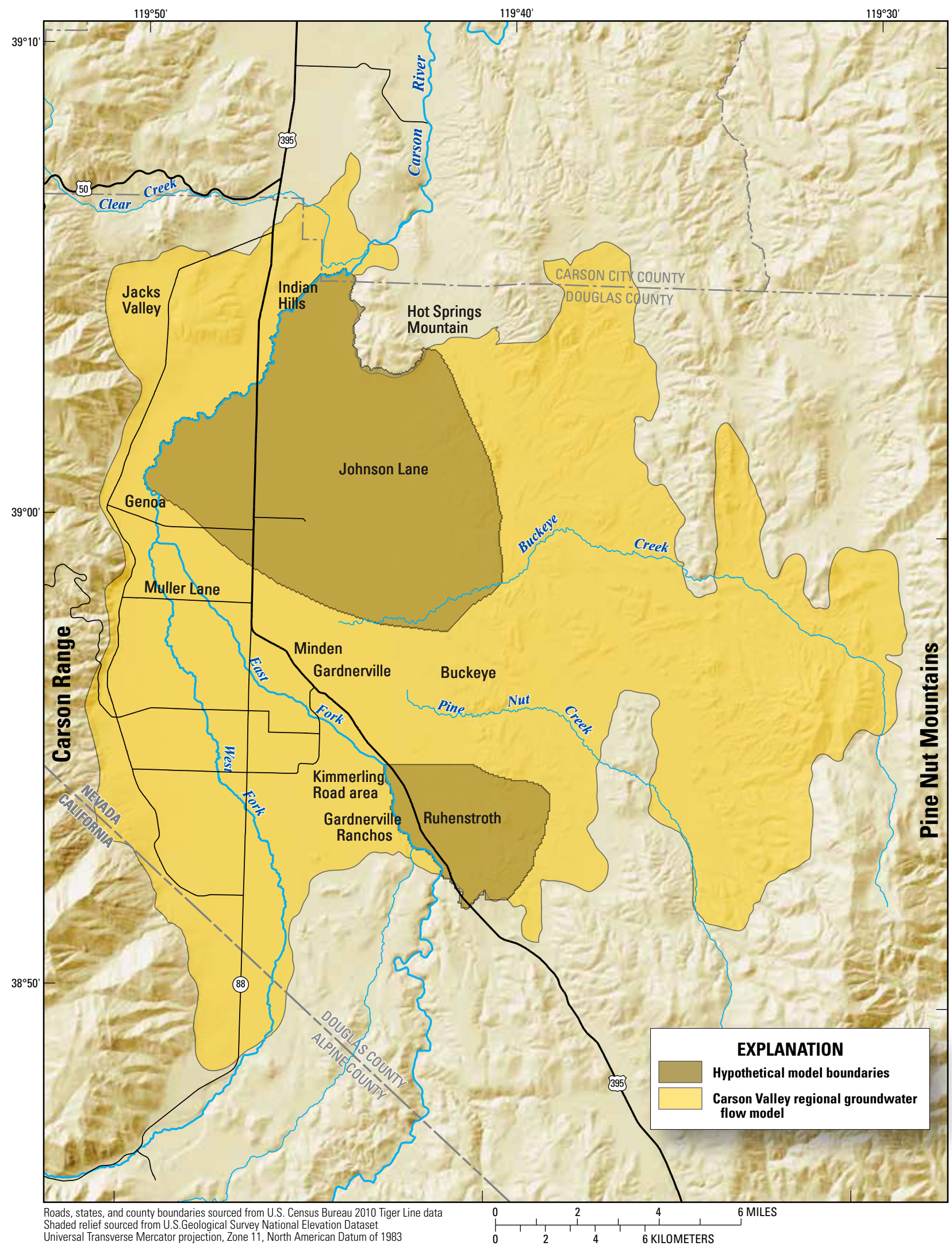

Figure 12. The boundaries of the Carson Valley regional groundwater-flow model from Yager and others (2012) and the transport models for the Johnson Lane and Ruhenstroth areas in Carson Valley, Nevada and California. 

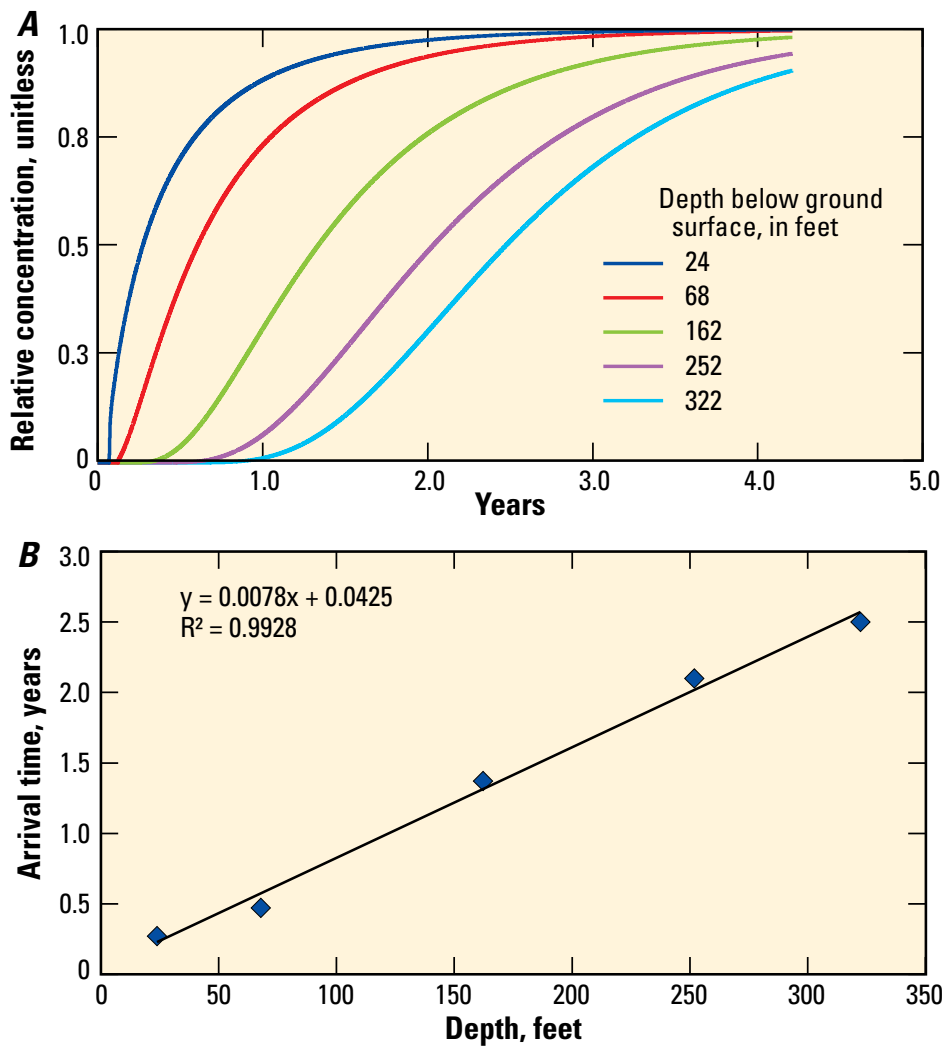

hydraulic conductivities assigned to the general head boundaries were adjusted until the flow rates through the boundaries and simulated water table were comparable to the flow rates and water table within the regional flow model of Yager and others (2012). No-flow boundaries were specified in the Johnson Lane model along the northern edge of the model domain at the contact between bedrock and alluvial-fan deposits near Hot Springs Mountain and along the southern edge along the Carson River (fig. 14A). No-flow boundaries were also specified in the Ruhenstroth model along the northern edge of the model domain, where groundwater was assumed to be moving perpendicular to the boundary and along the southern edge at the contact between bedrock and alluvial-fan deposits (fig. 15A).

Adjustments to the hydraulic conductivity from Yager and others (2013) were made in a limited area within the Ruhenstroth model where septic tanks and domestic wells were located in Tertiary sediments. It was necessary to increase the hydraulic conductivities of $0.05-0.5$ $\mathrm{ft} /$ year from Yager and others (2013) to 1,000 ft/yr in order to maintain flow from the southern boundary and match the measured water table in nearby wells. The resulting spatial distributions of hydraulic conductivity used in the models of Johnson Lane and Ruhenstroth are shown in figures $14 B$ and $15 B$.

Figure 13. VS2DT solute-breakthrough curves for different depths below land surface and mean arrival-time regression equation used for interpolation of results to Johnson Lane and Ruhenstroth transport models.

\section{Nitrate-N Transport in the Saturated Zone}

The three-dimensional flow and transport models were developed by using data from the regional groundwater-flow model developed by Yager and others (2012) for the Carson Valley (figs. 14 and 15). Confined steady-state simulations representing 1970 conditions provided initial conditions for 90-year transient simulations composed of annual time steps.

Separate models were developed for the Johnson Lane and Ruhenstroth areas with model domains that covered 62 and $14 \mathrm{mi}^{2}$, respectively, using grids composed of 208 -ft square cells. Each model domain was divided into 10 layers, with a specified thickness of the upper 9 layers as follows: layers $1-3,15 \mathrm{ft}$; layers 4-8, $30 \mathrm{ft}$; and layer 9, $200 \mathrm{ft}$. The thickness of layer 10 in each model was variable and extended from $395-\mathrm{ft}$ below the water table (the sum of the depth of the upper 9 layers) to the bottom of the basin fill.

The hydraulic properties (hydraulic conductivity and specific storage) and transient boundary conditions (recharge and groundwater withdrawals) from 1970 to 2005 specified in the models were taken from the regional groundwater-flow model (fig. 14A). Head dependent boundaries were specified to represent groundwater flow from the Pine Nut Mountains and groundwater discharge to the Carson River (fig. 15A). The

\section{Domestic wells and septic systems}

There are large differences in the size of the two transportmodel areas and the total number of septic tanks and pumping wells (domestic, agricultural, industrial). The total number of wells in the Johnson Lane and Ruhenstroth area is 2,627 and 511, respectively (figs. $14 C$ and $15 C$ ). The total number of septic tanks in Johnson land and Ruhenstroth is 1,433 and 500 , respectively. Normalized by area for Johnson Lane and Ruhenstroth, the number of septic-tank systems per square mile is 23 and 35, respectively. Individual septic systems contribute about 0.18 acre-ft/yr of recharge to the shallow aquifer, whereas pumping from individual domestic wells removes about 1.12 acre-ft/yr (State of Nevada, 2009). Septic systems are represented by injection wells in the top model layer (layer 1 ), and domestic wells are represented in layer 2. The numbers and locations of domestic wells and septic systems in the two modeled areas for each year from 1970 through 2009 are approximate and were taken from the regional flow model of Yager and others (2012). The total number of septic systems and wells in 2009 were assumed to remain constant through 2059 in the simulations. The nitrate-N concentration of septic leakage was assumed to be $40 \mathrm{mg} / \mathrm{L}$, as used in the VS2DT simulations. The specified arrival of nitrate-N from individual septic systems was delayed by the estimated arrival time through the unsaturated zone. The arrival time for each septic system was computed from the depth to the water table and the regression equation (equation 2) that was developed from the VS2DT results. 


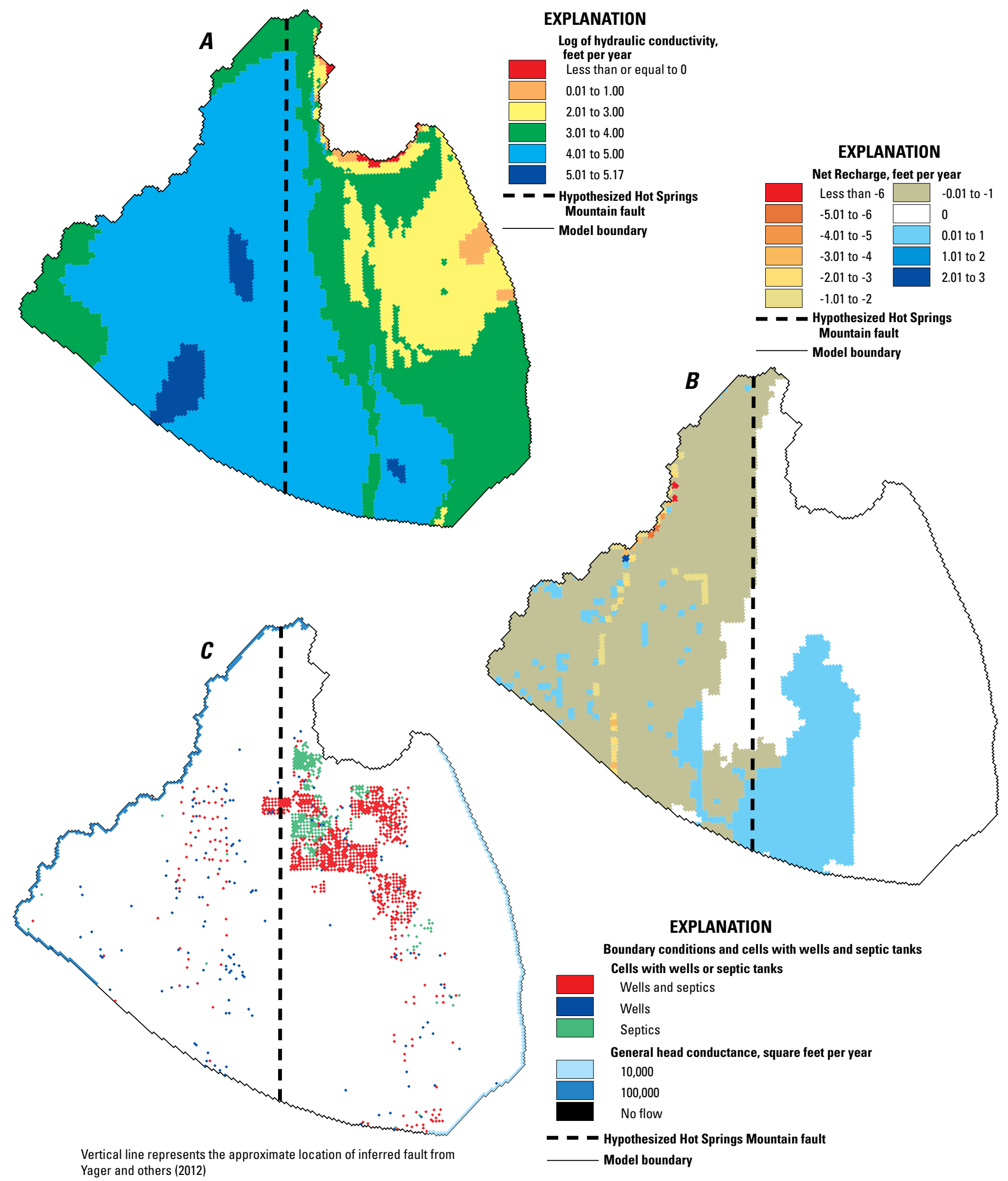

Figure 14. Diagrams showing the spatial distribution of input data for Johnson Lane hypothetical models: $A$, Log of hydraulic conductivity; $B$, Net recharge (precipitation + agricultural applications + channel infiltration - evapotranspiration); and $C$, Boundary conditions and cells with wells and septic tanks. 
A

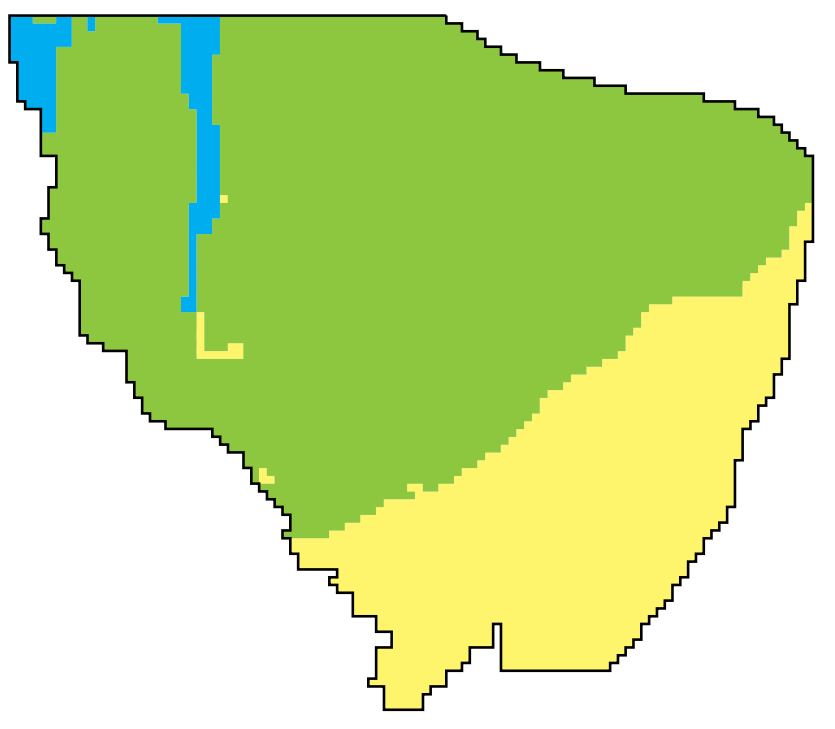

EXPLANATION

Net Recharge, feet per year

-0.01 to -1

0

0.01 to 1

1.01 to 2

2.01 to 3

3.01 to 4

Model boundary

\section{C}

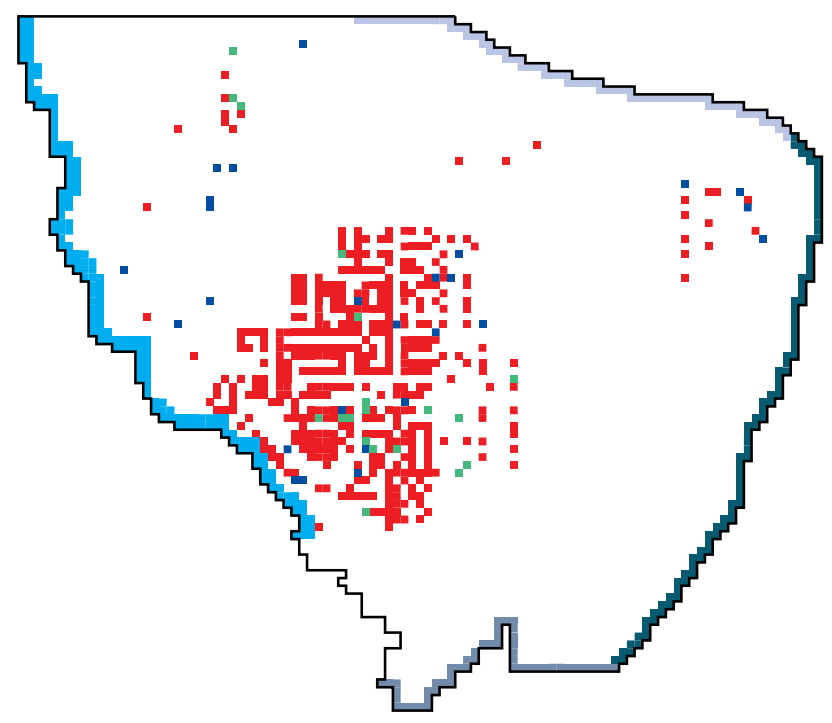

\section{EXPLANATION}

Log of hydraulic conductivity, feet per year

2.01 to 3.00

3.01 to 4.00

4.01 to 4.24

Model boundary
B

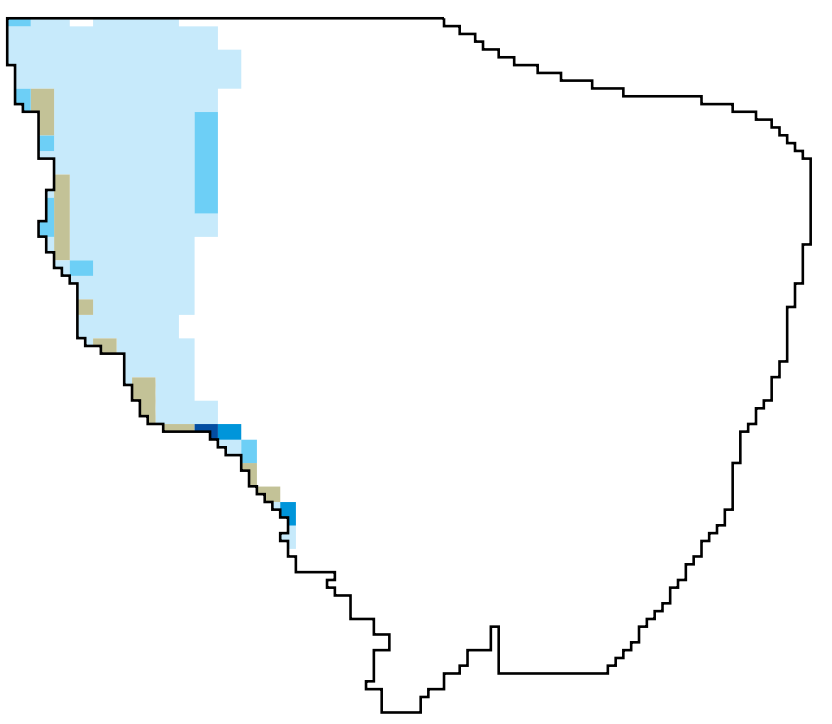

Figure 15. Diagrams showing the spatial distribution of input data for Ruhenstroth hypothetical models: $A$, Log of hydraulic conductivity; $B$, Net recharge (precipitation + agricultural applications + channel infiltration - evapotranspiration); and $C$, Boundary conditions and cells with wells and septic tanks. 
The migration of nitrate- $\mathrm{N}$ in groundwater was simulated using the Total Variation Diminishing (TVD) solution in MT3DMS (Zheng and Wang, 1999). Background nitrate-N concentrations in the valley tended to be less than $1.0 \mathrm{mg} / \mathrm{L}$ (Rosen, 2003), and no sources of natural nitrogen were measured in the modeled area. Therefore, it was assumed that the regional groundwater background nitrate- $\mathrm{N}$ concentration was $0.0 \mathrm{mg} / \mathrm{L}$. The specified source concentration of $40 \mathrm{mg} / \mathrm{L}$ at the grid cells was assumed to be constant at the arrival time simulated by VS2DT.

\section{Transport Parameters and Assumptions}

The transport parameters used in this modeling effort were not measured; instead, complete nitrification (conversion from ammonia to nitrate) was assumed. Therefore, all nitrogen entering the aquifer through the unsaturated zone was in the form of nitrate-N. This assumption was based on data from 27 groundwater samples that were analyzed for ammonia, 26 of which had concentrations less than $0.02 \mathrm{mg} / \mathrm{L}$. Denitrification was assumed to be negligible on the basis of the concentrations of dissolved oxygen, dissolved gas, and nitrogen and oxygen-isotopes. For this reason, reduction of nitrate through biochemical processes was not simulated. Molecular diffusion was assumed to be much smaller than mechanical dispersion and was, therefore, neglected. A retardation factor of 1.0 was specified, assuming no sorption of nitrate-N. Effective porosity, which affects the rate of transport, was defined uniformly to 0.20 on the basis of sand and gravel aquifer material (Fetter, 1994). Longitudinal, transverse, and vertical dispersivities are scale dependent and affect the amount of plume spreading. Longitudinal, transverse, and vertical dispersions were assigned values of $210 \mathrm{ft}, 21 \mathrm{ft}$, and $2.1 \mathrm{ft}$, respectively (Gelhar and others, 1992).

\section{Numerical Transport-Model Results and Discussion}

\section{Groundwater-Flow and Transport Models}

The purpose of the modeling effort was to simulate nitrate-N transport under current and future conditions, and to evaluate hypothetical scenarios for managing septic system usage and domestic water supply. The hypothetical scenarios were used to address concerns regarding the regional use of septic tanks systems - namely, (1) septic usage and domestic pumping were held constant given 2009 records (predictive), (2) discontinued use of septic systems in 2030 (H1), and (3) discontinued use of septic systems and termination of domestic well pumpage in 2030 (H2). Simulated concentrations at 2059 were compared among the predictive and hypothetical scenarios.

\section{Groundwater Flow}

The strategy for the simulation of groundwater flow for each area was to approximate the water levels from the regional groundwater-flow model through the adjustments of the general head boundary conductance. The boundary conductance is a numerical parameter that represents the resistance to flow between the boundary head and the model domain. These models were not designed to exactly replicate the regional flow in the shallow aquifer for any particular time or location but rather to simulate the general flow direction while maintaining consistency with the hydraulic parameters and net recharge (precipitation + agricultural applications + channel infiltration - evapotranspiration) defined in the regional flow model. Simulated water levels for both the Johnson Lane and Ruhenstroth areas show a comparable pattern in flow direction and gradients between the local and regional scale models (fig. $16 A$ and $16 B$ ). Differences between the simulated water levels in the regional flow model and the models for the two areas could be the result of differences in the flow simulated to the areas from the Pine Nut Mountains associated with the general head boundary.

\section{Nitrate-N Transport}

Solute breakthrough curves derived from VS2DT model were analyzed from vertically distributed cells to determine the mean arrival time as a function of depth. A linear regression equation between the depth to water and arrival time was developed for both Johnson Lane and Ruhenstroth areas given no attenuation or sorption of nitrate- $\mathrm{N}$ through the unsaturated zone. For a medium sand texture, the relationship between depth to water and arrival time is calculated as follows:

$$
A T=(0.0078 \times d w+0.0425)
$$

where
$A T$ is arrival time in years, and
$d w \quad$ is the depth to the water table ( $\mathrm{ft})$.

Approximate arrival times for Johnson Lane and Ruhenstroth ranged from 1 to 5 years, given a depth to water range from 1 to $300 \mathrm{ft}$. The timing of nitrate-N loading to the aquifer was determined by adding the arrival time estimated by VS2DT to the year the septic-tank system was installed (fig. 17A). More than 4,500 septic systems were in use as of 2009, and septic densities locally exceeded the density of one septic system per 3 acres, above which increasing concentrations in groundwater were reported by Shipley and Rosen, 2005. In general, nitrate-N loading to the aquifer at Johnson Lane and Ruhenstroth arrives within the first year of installation because of the relatively shallow depth to water and the flux rate of septic systems (fig.17B and 17C). At Johnson Lane, the installation of septic tanks increased abruptly during 1977-81 and 1988-94 to an average rate of 72 septics per year. In Ruhenstroth, the total and change in septic-tank system installation per year was lower and, averaged over the same two periods, 


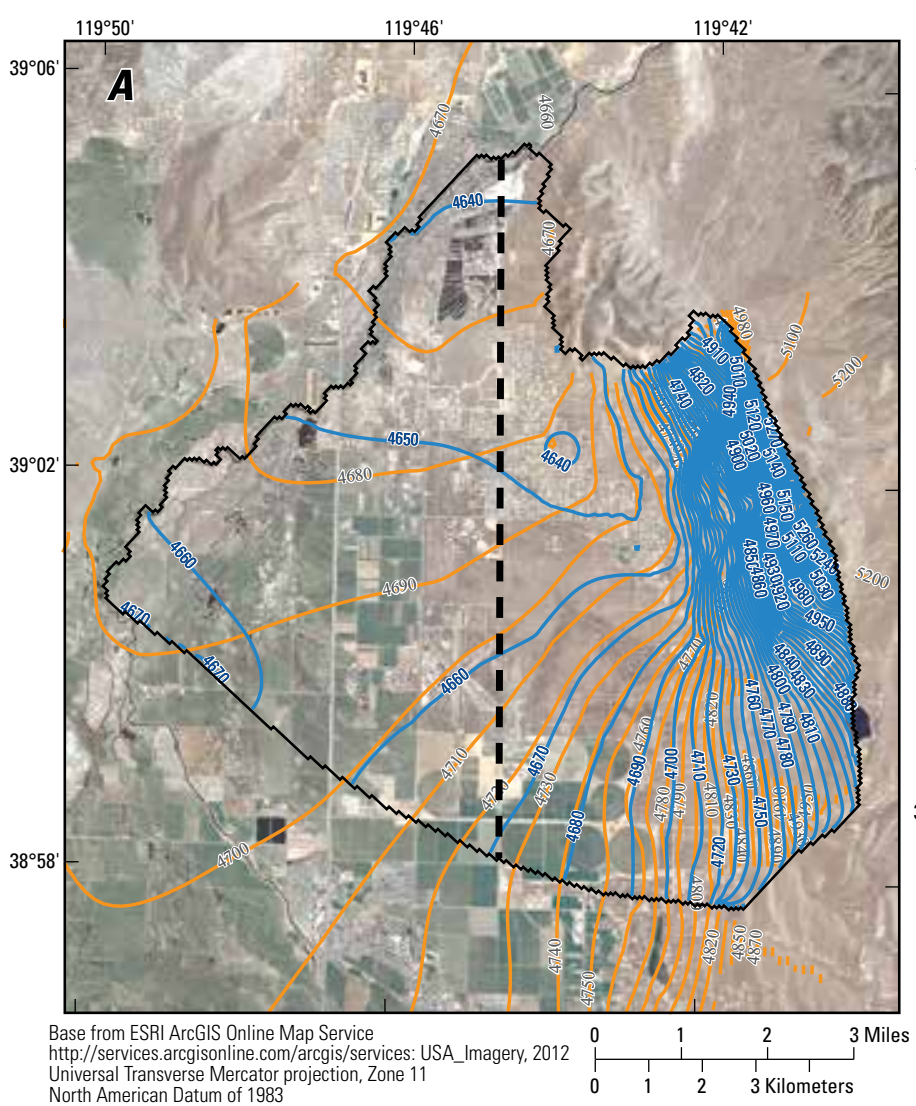

Vertical line represents the approximate location of inferred fault from Yager and others, 2012

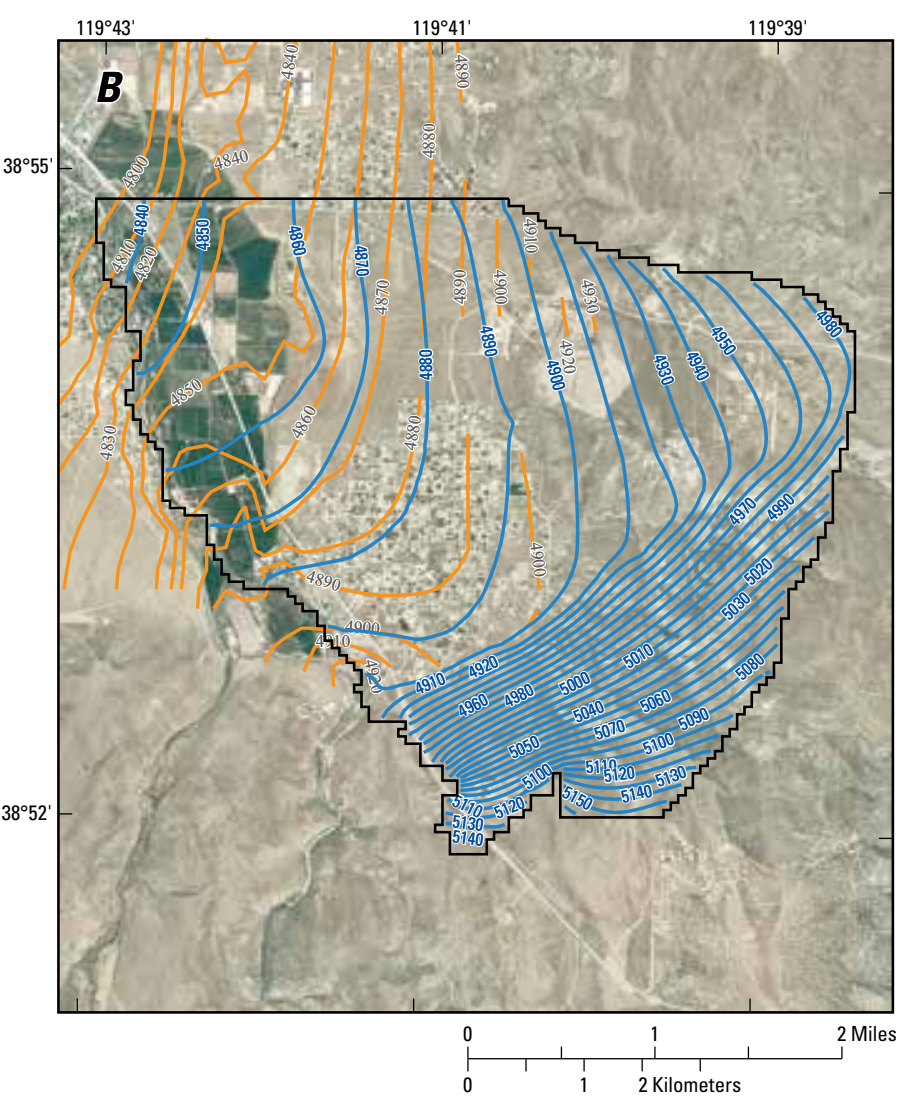

EXPLANATION

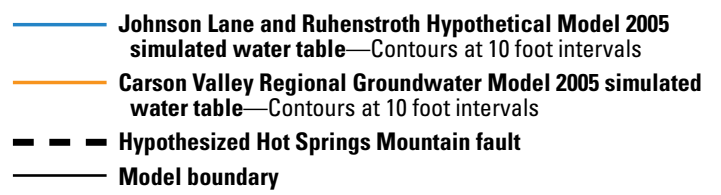

Figure 16. Hypothetical scenario model 2005 simulated water table compared to Carson Valley regional groundwater model 2005 simulated water table for $A$, Johnson Lane and $B$, Ruhenstroth in Carson Valley, Douglas County, Nevada.

increased only 20 septics per year. The average depth to water at Johnson Lane and Ruhenstroth, where septic tanks are located, is $70 \mathrm{ft}$ and $120 \mathrm{ft}$, respectively.

Although no attempt was made to estimate transport parameters through calibration, the error between observed and simulated nitrate- $\mathrm{N}$ results is reported to indicate how well the model reproduced 2008-09 concentrations. The error statistics used in this evaluation were root mean square error (RMSE) and percent bias (PB). RMSE is a commonly used error statistic for determining the residual variance of the error between measured and simulated results. Percent bias measures the average tendency of the simulated data to be more or less than the observed. Positive values indicate over estimation, and negative values indicate underestimation, of the bias. In both error statistics, a zero value indicates a perfect fit between the observed and simulated data. In transient solute-transport simulations, the error can be associated with timing, mass loading, groundwater-flow velocities, and inadequate estimation of the drawdown associated with pumping.

Comparisons between simulated (2009) and observed (2008-09) concentrations for Johnson Lane and Ruhenstroth areas are shown in figures 18 and 19, respectively. The model comparisons illustrated general agreement between simulated and observed data and the spatial distribution of concentrations. The Johnson Lane model had a positive bias for observed concentrations less than $4.0 \mathrm{mg} / \mathrm{L}$ (fig. 18A), while the Ruhenstroth had little bias (fig. 19A). The combined RMSE for the two models was $3.9 \mathrm{mg} / \mathrm{L}$, or 22 percent of the measurement range. 


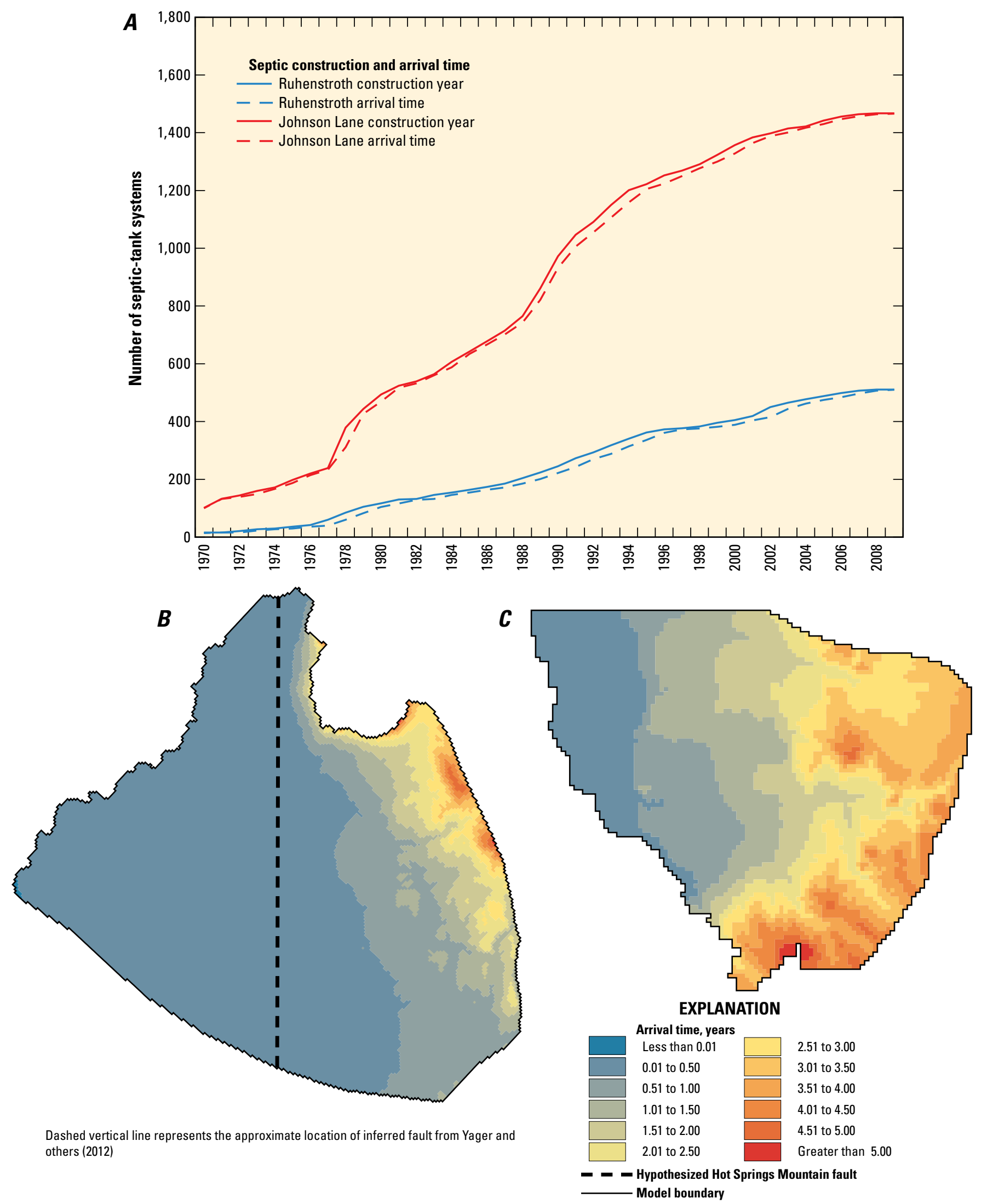

Figure 17. A, The cumulative number of septic tanks by year; and $B$, diagrams showing the spatial distribution of arrival times for Johnson Lane and $C$, Ruhenstroth transport models. 

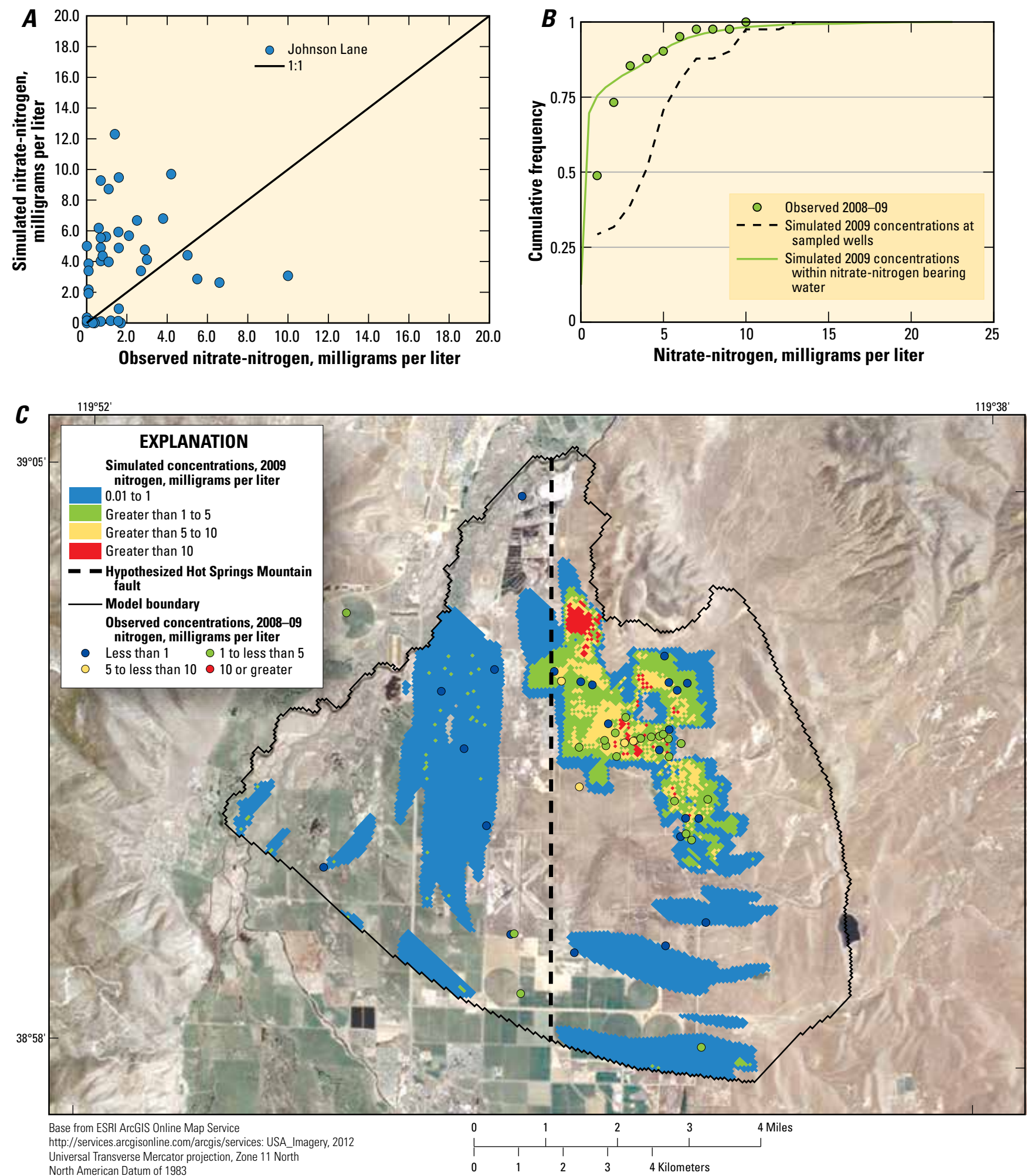

Figure 18. Observed 2008-09 compared to simulated 2009 nitrate as nitrogen (N) concentrations for the Johnson Lane model 2009 time-step: $A$, Observed compared to simulated; $B$, Observed compared to simulated at observation cells and all cells; and $C$, Map depicting spatial distribution of nitrate-N 2009 time step with observed nitrate-N concentrations for 2008-09. 

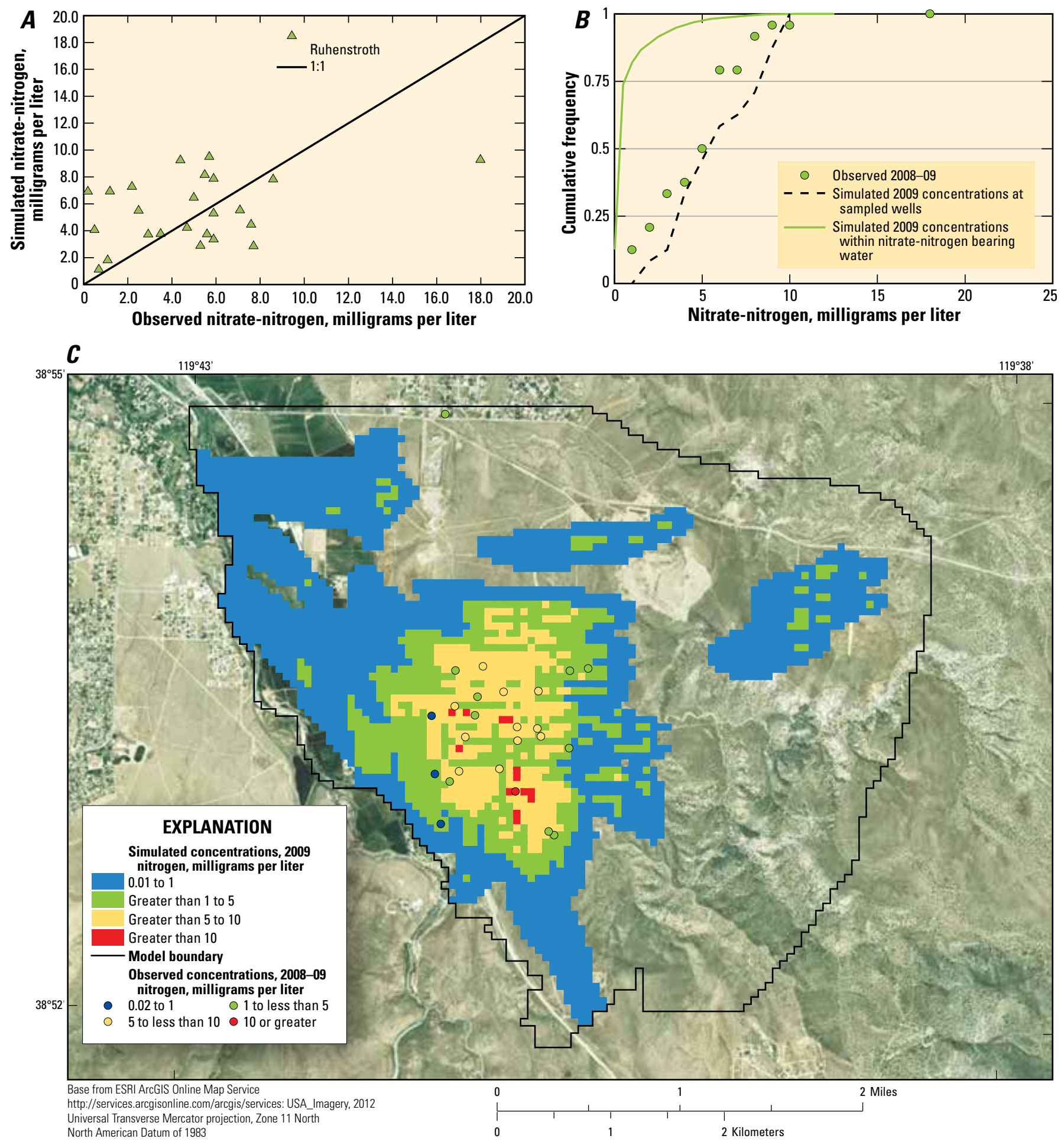

Figure 19. Observed 2008-09 compared to simulated nitrate as nitrogen (N) concentrations for the Ruhenstroth model 2009 time-step: $A$, Observed compared to simulated; $B$, Observed compared to simulated at observation cells and all cells; and $C$, Map depicting spatial distribuiton of nitrate-N 2009 time step with observed Nitrate-N concentrations for 2008-09. 
The cumulative distribution function (CDF) of observed and simulated concentrations was prepared for both transport models at local and regional scales (figs. $18 B$ and 19B). The CDFs at the local grid scale were obtained from observations wells collected in 2008-09 and were compared to simulated 2009 results. The regional CDFs were prepared for all grid cells within the transport model boundaries. When compared to the local grid scale, the CDF can be used to show the transport-model performance over the entire range of nitrate- $\mathrm{N}$ within the model as compared to the observed data for 2008-09. The CDF for simulated concentrations at the sampled wells indicated a positive bias $(\mathrm{PB}=124$ percent $)$ in the Johnson Lane model for the entire range of concentrations (fig. 18B). The CDF for simulated concentrations at regional scale or all grid cells containing nitrate-bearing water was similar to the CDF for the observed concentrations, indicating that the model closely reproduced the distribution of nitrate based on the 2008-09 data, and the distribution of data collected was unbiased. At Ruhenstroth, the transport model was able to reproduce the local scale observed distribution ( $\mathrm{PB}=$ 14 percent), with the exception of the maximum concentration $(18 \mathrm{mg} / \mathrm{L})$, as shown in figure $19 B$. The distribution of the simulated concentrations at the local grid scale, however, did not coincide with the regional distribution, which indicated a bias in sample design. The difference in the pattern of bias results from the fact that the majority of the samples in the Ruhenstroth area were within residential areas, whereas at Johnson lane, the samples were distributed more evenly to include the agricultural and vacant land.

The Johnson Lane model simulated transport of nitrate-N along the regional gradient toward the Carson River and accumulating east of the hypothesized north-south fault of Yager and others (2012), where the shallow aquifer thins (fig. 18C). The areas with the highest concentrations were located down gradient of the suburban development, just south of Hot Spring Mountain. The Ruhenstroth model simulated transport toward the East Fork of the Carson River and pumped agricultural wells (fig. 19C). The areas with the highest concentration were located within the suburban development and did not extend beyond its boundaries. Simulated concentrations greater than $10 \mathrm{mg} / \mathrm{L}$ were collocated with older septic-tank systems that had been loading nitrate- $\mathrm{N}$ to the aquifer the longest.

\section{Hypothetical Scenarios}

Three hypothetical scenarios were used to evaluate future effects (2009-59) of nitrate-N transport in the aquifer: (1) Predictive, where septic usage and domestic pumping were held constant; (2) H1, discontinued use of septic systems; and (3) $\mathrm{H} 2$, discontinued use of septic systems and termination of domestic well pumpage. In H1, all septic systems were removed in 2030, but wells continued to pump groundwater. For H2, all domestic wells and septic systems were removed in 2030, but industrial, agricultural, and municipal wells continued to pump groundwater. These simulations were compared to the predictive model at 2059 to assess the effect of removing wells and septic systems on simulated concentrations.

The simulated maximum concentrations, the total areas where the concentration exceed the MCL of $10 \mathrm{mg} / \mathrm{L}$, and calculated percentage changes from 2009 to 2059 for Johnson Lane and Ruhenstroth models, are shown in table 4 . The maximum concentration increased from $22 \mathrm{mg} / \mathrm{L}$ to $30 \mathrm{mg} / \mathrm{L}$ ( 38 percent increase) under the base scenario in the Johnson Lane model and resulted in a larger area where $\mathrm{N}$ concentrations exceeded the MCL by 139 percent. Discontinuing the use of septic-tank systems in 2030 (H1) in the Johnson Lane model resulted in a 34 percent decrease in maximum concentration $(20 \mathrm{mg} / \mathrm{L})$ and 75 percent decrease in areas greater than the MCL. The maximum concentration increased from $12 \mathrm{mg} / \mathrm{L}$ to $19 \mathrm{mg} / \mathrm{L}$ (62 percent increase) under the base scenario in the Ruhenstroth model, and this resulted in 769 percent increase in the total area that exceeded the MCL.

The timing to the peak concentration and the change in concentration with respect to time are shown for layer 1 within the septic tank areas for both transport models in figure 20. The H1 hypothetical scenario model results indicated a lower concentration in 2059 and a more drastic decrease in concentration from 2030 to 2059 . The overall loading of Nitrate-N had not reached a steady concentration in 2059 because of a delay in the arrival of nitrate- $\mathrm{N}$ to the aquifer resulting from the depth to water and the installation date of the septic-tank systems (fig. 20).

The spatial distribution of the simulated concentrations for the 2009 , predictive, $\mathrm{H} 1$ and $\mathrm{H} 2$ hypothetical scenarios are shown in figures 21 and 22 for the Johnson Lane and Ruhenstroth models, respectively. At Johnson Lane, concentrations simulated between 1 and $5 \mathrm{mg} / \mathrm{L}$ occur along the south and

Table 4. Simulated maximum nitrate as nitrogen concentration, total area exceeding the maximum contaminant level (MCL) of 10 milligrams per liter in 2009, 2059, and for the hypothetical scenarios where discontinued use of septic systems (H1), and discontinued use of septic systems and domestic-well pumping (H2).

$[\mathrm{mg} / \mathrm{L}$, milligrams per liter; - , no data; >, greater than $]$

\begin{tabular}{|c|c|c|c|c|}
\hline & \multirow{2}{*}{2009} & \multicolumn{3}{|c|}{2059} \\
\hline & & Prediction & H1 & H2 \\
\hline \multicolumn{5}{|c|}{ Johnson Lane } \\
\hline Maximum (mg/L) & 22 & 30 & 20 & 19 \\
\hline Percentage change in maximum ${ }^{1}$ & - & 38 & -34 & -39 \\
\hline Acres $>$ MCL $(10$ mg/L) & 156 & 373 & 92 & 48 \\
\hline Percentage change in area ${ }^{1}$ & - & 139 & -75 & -87 \\
\hline \multicolumn{5}{|c|}{ Ruhenstroth } \\
\hline Maximum (mg/L) & 12 & 19 & 4 & 5 \\
\hline Percentage change in maximum ${ }^{1}$ & - & 62 & -79 & -72 \\
\hline Acres $>$ MCL $(10 \mathrm{mg} / \mathrm{L})$ & 11 & 112 & 0 & 0 \\
\hline Percentage change in area $^{1}$ & - & 769 & -100 & -100 \\
\hline
\end{tabular}

${ }^{1}$ Calculated as a percentage from prediction at 2059. 


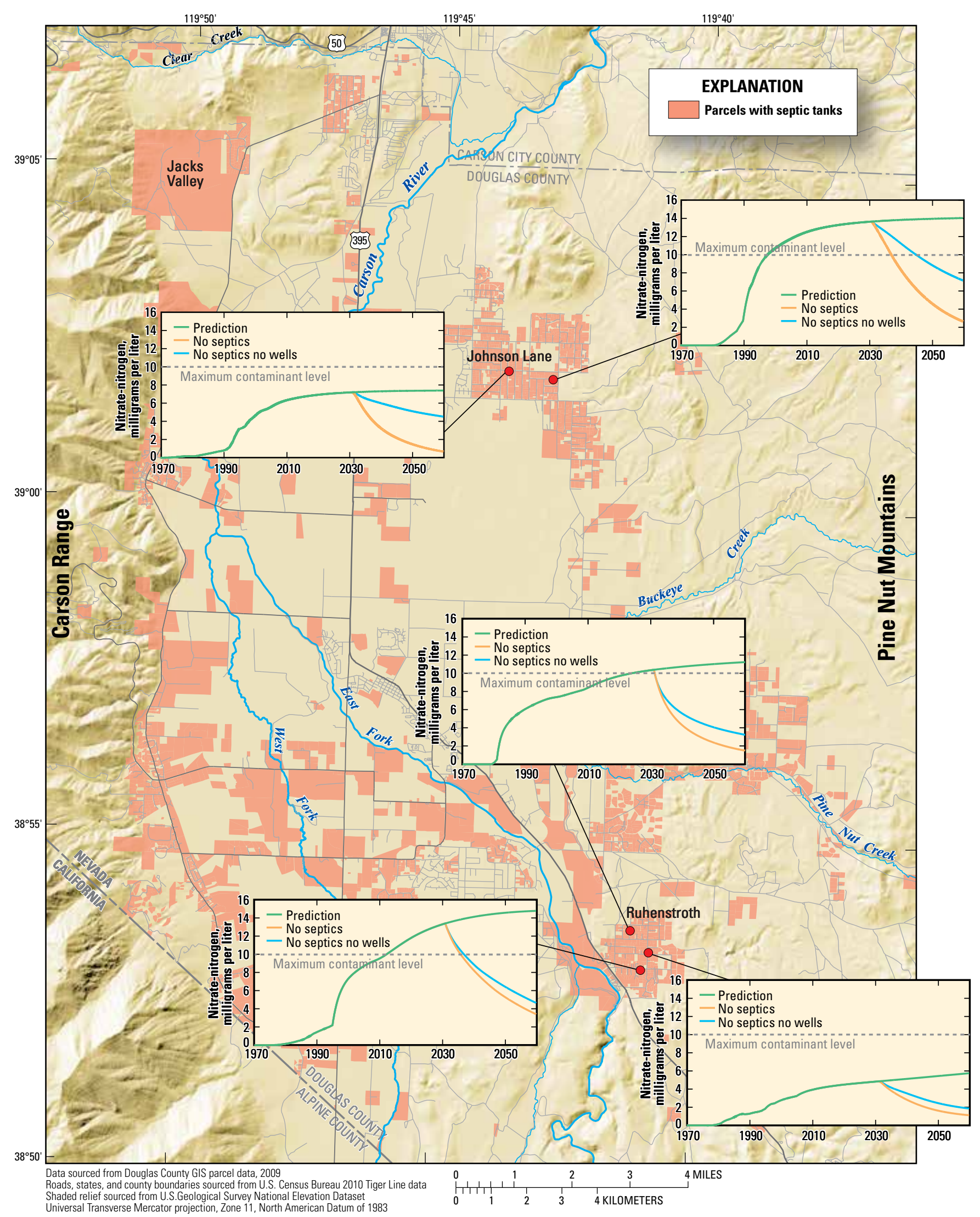

Figure 20. Distribution of simulated nitrate as nitrogen concentrations within the Johnson Lane and Ruhenstroth transport models from 1970-2059 for hypothetical scenarios of discontinued use of septic systems in 2030 (H1) and discontinued use of septic systems and domestic-well pumping in 2030 (H2). 

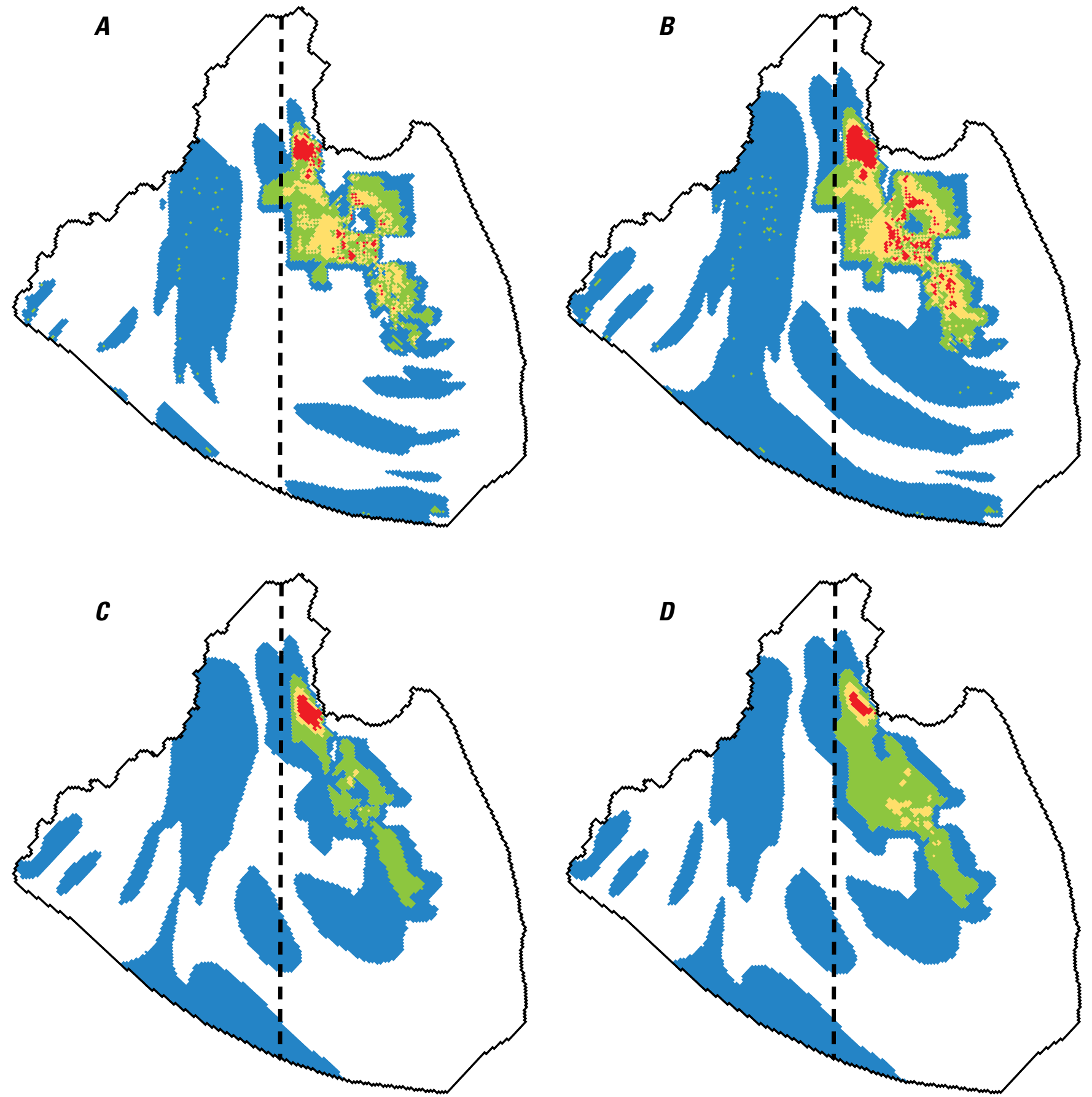

\section{EXPLANATION}

Nitrogen, milligrams per liter 0.01 to 1

Greater than 1 to 5 Greater than 5 to 10

Greater than 10

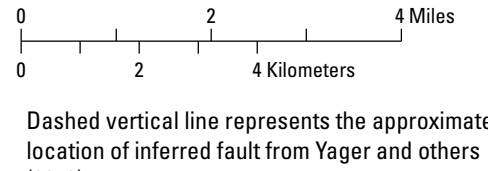

- - Hypothesized Hot Springs Mountain fault location of inferred fault from Yager and others (2012)

Model boundary

Figure 21. Distribution of simulated nitrate as nitrogen concentrations at Johnson Lane: $A, 2009 ; B, 2059 ; C, 2059$ discontinued use of septic systems in $2030(\mathrm{H} 1)$; and D, 2059 discontinued use of septic systems and domestic-well pumping in 2030 (H2). 
$\boldsymbol{A}$

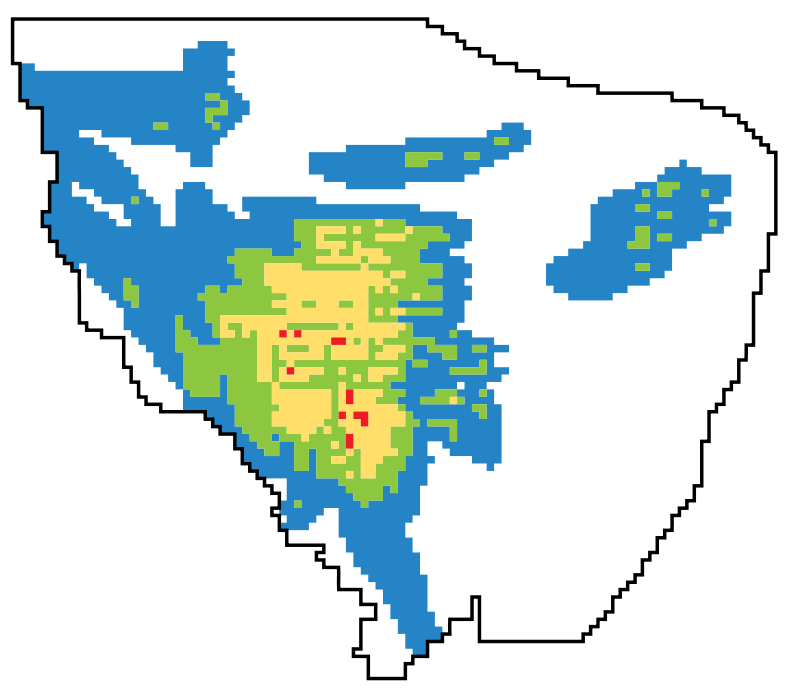

C

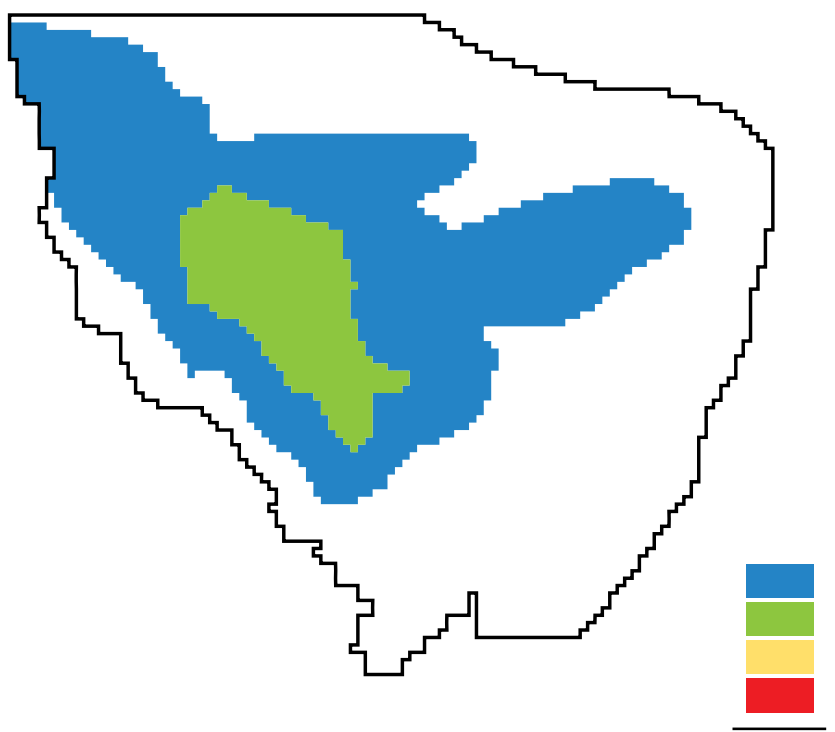

$B$

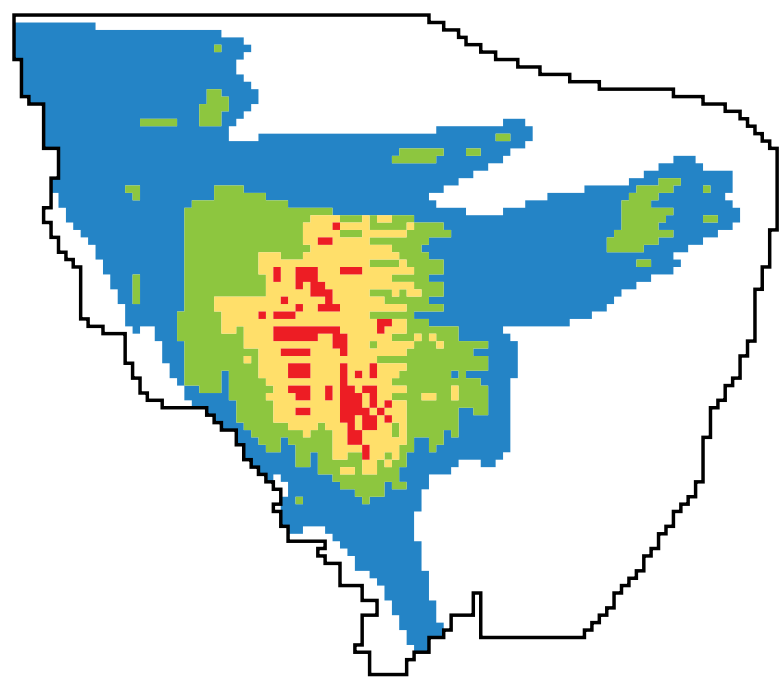

D

EXPLANATION

Nitrogen, milligrams per liter 0.01 to 1

Greater than 1 to 5

Greater than 5 to 10

Greater than 10

Model boundary

Figure 22. Distribution of simulated nitrate as nitrogen concentrations at Ruhenstroth: $A, 2009 ; B, 2059 ; C, 2059$ discontinued use of septic systems $2030(\mathrm{H} 1)$; and $D, 2059$ discontinued use of septic systems and domestic-well pumping 2030 (H2).

southeast direction controlled by the regional flow toward and parallel to the Carson River. In 2059, the nitrate-N plumes in the eastern area commingled with plumes in the center of the model, where the hydraulic conductivity is higher relative to upland areas (fig. 21B). Just south of Hot Springs Mountain the transport models showed an accumulation of nitrate- $\mathrm{N}$ that was constrained by low permeability bedrock, an inferred north-south fault, the convergence of low regional-flow gradients from the east and south, and a lack of groundwater pumping that would remove mass (fig. $21 B$ ). The model estimated concentrations greater than the MCL of $10 \mathrm{mg} / \mathrm{L}$ in areas where septic-tank systems existed and there was no groundwater pumping to remove mass. For Johnson Lane, the
H1 hypothetical scenario results indicated a reduction in the spatial distribution of concentrations in the $5-10 \mathrm{mg} / \mathrm{L}$ range, but the area south of Hot Spring Mountain continued to have concentrations greater than $10 \mathrm{mg} / \mathrm{L}$ (fig. 21C). Comparison between $\mathrm{H} 1$ and $\mathrm{H} 2$ hypothetical scenarios for Johnson lane indicated the concentrations between 1 and $5 \mathrm{mg} / \mathrm{L}$ remained in the aquifer because of the limited influence of mass removal from domestic pumping (fig. $21 C$ and $21 D$ ). Therefore, reductions in concentrations would be through transport processes (dispersion) and non-domestic pumping (agricultural, industrial, and municipal).

In the Ruhenstroth predictive model from 2009 to 2059 , there was transport of nitrate- $\mathrm{N}$ in the lower concentration 
range (less than $5 \mathrm{mg} / \mathrm{L}$ ) originating from the east toward an agricultural well located in the north and northwest, parallel with the East Fork Carson River (fig. 22). Concentrations in the mid-range $(5-10 \mathrm{mg} / \mathrm{L})$ appeared to change little from 2009 to 2059 (fig. 22B). In the center of the development, concentrations greater than $10 \mathrm{mg} / \mathrm{L}$ were not spatially continuous and did not appear to be moving from the source area. There were negligible differences between $\mathrm{H} 1$ and $\mathrm{H} 2$ spatially, with only a slightly larger foot print in the $1-5 \mathrm{mg} / \mathrm{L}$ range and a small area in the $5-10 \mathrm{mg} / \mathrm{L}$ range in $\mathrm{H} 2$ (fig. $22 \mathrm{C}$ ).

A comparison of the cumulative distribution among the numerical models for Johnson Lane indicated there was almost no change in concentration below the 80 th percentile value, indicating low concentrations (less than $2 \mathrm{mg} / \mathrm{L}$ ) would persist to 2059 regardless of whether the base, $\mathrm{H} 1$, or $\mathrm{H} 2$ scenario was followed (fig. 23A). The greatest changes in simulated concentrations were above the 90th percentile value, and there was almost no change in the overall distribution of simulated concentrations. In contrast, in the Ruhenstroth area, there was a 50 percent decrease (from 1.1 to $0.5 \mathrm{mg} / \mathrm{L}$ ) in concentration at the 80th percentile among the base, $\mathrm{H} 1$, and $\mathrm{H} 2$ scenarios (fig. 23B). The greatest changes in simulated concentrations at Ruhenstroth were also in the less frequent (greater than 80th percentile) range (1-3 mg/L), indicating groundwater effects from septic-tank systems were localized. This could result from removal of nitrate- $\mathrm{N}$ through domestic pumping, combined with limited migration from residential areas. Overall simulated concentrations in 2009 above the median (50th percentile) were greater at Johnson Lane than Ruhenstroth as a result of greater loading and higher concentrations simulated in the aquifer.

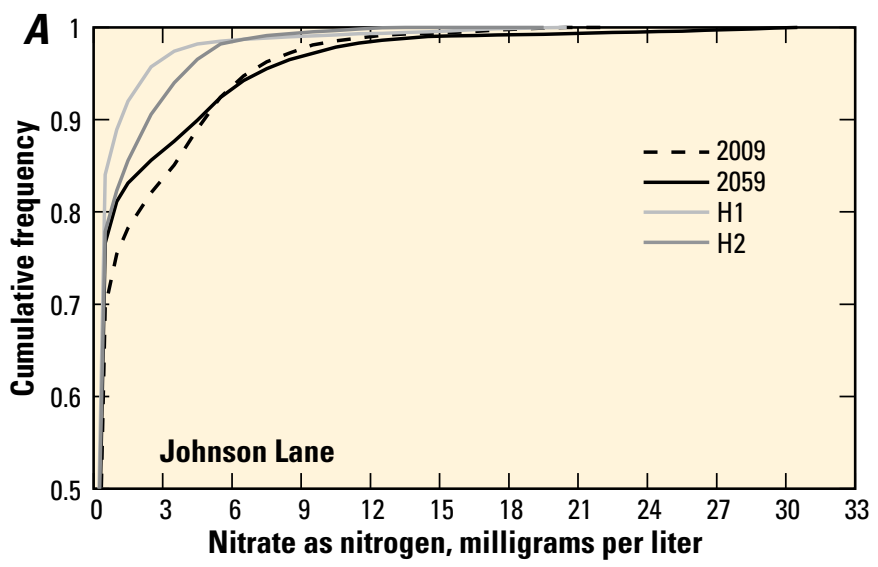

\section{Sensitivity Analysis}

A sensitivity analysis was used to examine the sensitivity of simulated nitrate- $\mathrm{N}$ concentrations to the following model parameters: porosity, dispersion, horizontal hydraulic conductivity, and nitrate- $\mathrm{N}$ concentrations in septic leakage. The simulated concentrations are sensitive to a parameter when a small change in the parameter value causes a large change in the simulated concentration. The sensitivity of simulated minimum, average, and maximum concentrations predicted for 2059 was determined by increasing or decreasing each parameter value individually. This analysis evaluated the sensitivity of hydraulic and transport parameters at the observation wells. The results of the sensitivity analysis were expected to differ greatly throughout each model area from what was evaluated in this report because of the location of the observations relative to the areas having the greatest concentrations. Such was the case at Johnson Lane, where there were no observations in proximity to or in the area of the simulated highest concentrations.

The simulated minimum, average, and maximum concentrations for the Johnson Lane and Ruhenstroth areas are summarized in figure 24. Dispersion, hydraulic conductivity, and source concentration were sensitive parameters when compared to the prediction results for the maximum simulated concentrations at Johnson lane (fig. 24A). Decreases in dispersivity by half resulted in a nearly equal (40 percent) increases in maximum concentration. This is due to reduction of transport and accumulation of nitrate-N. Changes in hydraulic conductivity and porosity generally resulted in minimal changes to the minimum and average concentrations. Adjustments to parmeter values resulted in no increase in minimum values from zero concentration at Johnson Lane.

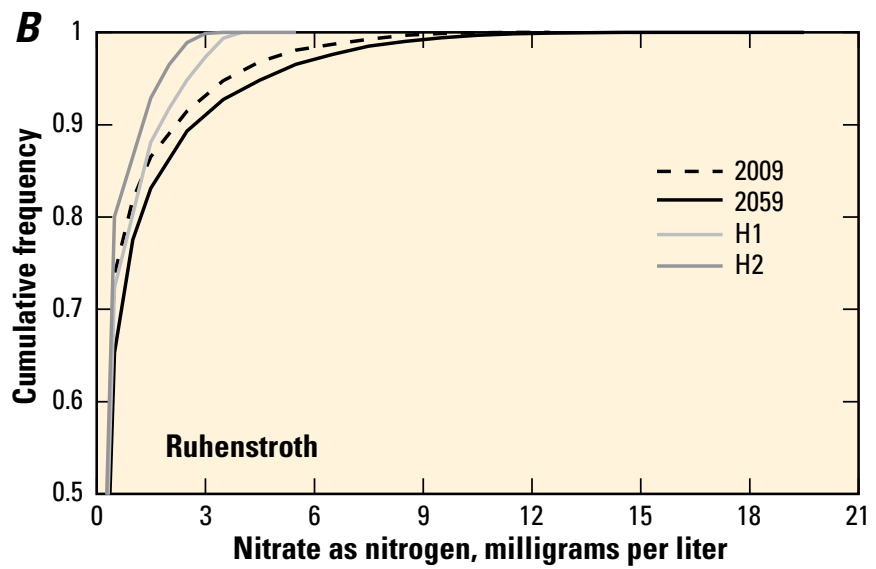

Figure 23. The cumulative distribution of simulated nitrate as nitrogen concentrations at 2009, 2059, and $\mathrm{H} 1$ and $\mathrm{H} 2$ scenarios with the removal of septic systems $(\mathrm{H} 1)$ and domestic pumping $(\mathrm{H} 2 ; 2030)$ at $A$, Johnson and $B$, Ruhenstroth areas. 
An increase in the hydraulic conductivity resulted in a reduction of the maximum concentration from 14.0 to $9.6 \mathrm{mg} / \mathrm{L}$ (31 percent) due to increased transport. Decreasing the source concentration at Johnson Lane from 40 to $20 \mathrm{mg} / \mathrm{L}$ resulted in an equal change in max concentration from 14.0 to 7.0 $\mathrm{mg} / \mathrm{L}$ (factor of two from the prediction results). Increases in the source concentration had a minimal effect on the maximum concentration simulated at the observation cells. This indicated that other variables, such as pumping or transport, could have a greater influence on the loading at Johnson Lane given the locations of the observations cells relative to the source area. It is anticipated if additional wells were located in the source area, increasing the source concentration would reflect greater changes in the maximum concentrations. In Ruhenstroth, porosity and source concentration were the most sensitive parameters. Reducing the porosity by 50 percent had an equal change in minimum, average, and maximum nitrate$\mathrm{N}$ concentrations because of increased transport away from the observation wells (fig. 24B). Similarly, decreasing the source concentration at Ruhenstroth from 40 to $20 \mathrm{mg} / \mathrm{L}$ resulted in an equal change in maximum concentration from 14.0 to 7.0 $\mathrm{mg} / \mathrm{L}$ (factor of two). In Ruhenstroth, a doubling of the source concentration would increase the maximum concentration by the same amount (factor of two). The sensitivity of the source concentration reflected the proximity of the observation wells to the source areas, as shown in figure $19 C$.

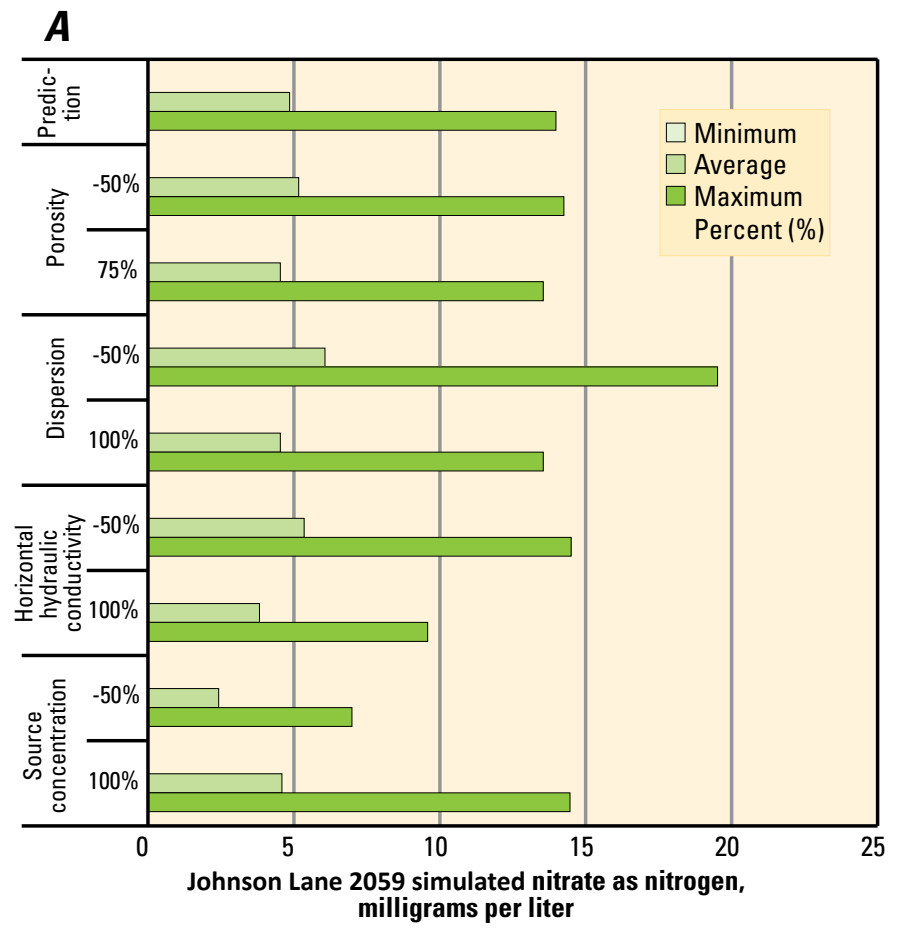

\section{Limitations of the Analysis}

The number of wells sampled in each land-use category could be a limitation to the analysis presented in this report. A more comprehensive representation of agricultural land use and vacant land than was sampled for the study could have provided better statistical differences between land uses and nitrate-N concentrations. However, wells were limited in these areas, and drilling new wells was beyond the resources of this study. Nevertheless, more than 200 wells were sampled over a year, which gives a relatively robust statistical basis for the analysis. More directed sampling of areas with higher nitrate-N concentrations could possibly have provided a better delineation of hot spots predicted by the models. Given the resources available for the study, the amount of sampling was not a major limitation.

The numerical models described in this report are useful for evaluating the generalized movement of nitrate- $\mathrm{N}$ with hypothetical changes in septic-tank usage and domestic pumping; however, the model is a simplified representation of a complex physical system. The accuracy of the numerical models are based on several critical assumptions: 1) the nitrate- $\mathrm{N}$ concentration of septic-system leakage is uniform $(40 \mathrm{mg} / \mathrm{L})$ and constant; 2) the unsaturated zone can be represented by a single, homogenous deposit with moderate infiltration rates; and 3) the regional groundwater-flow model adequately represents the flow and stresses (pumping, drawdown) of the alluvial

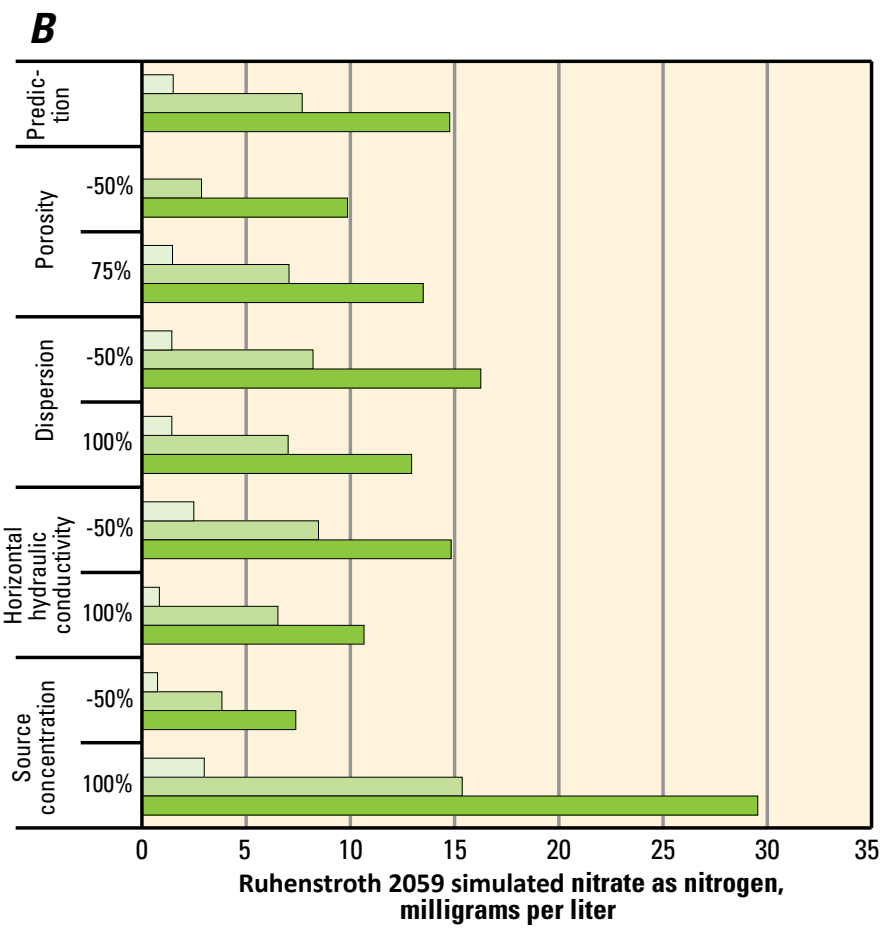

Figure 24. Summary of concentrations at observations given incremental changes to transport parameters located at $A$, Johnson Lane, and $B$, Ruhenstroth model areas, where prediction corresponds to base case simulation. 
aquifer. Sensitivity analysis indicated that the most uncertain parameters (source concentration, hydraulic conductivity, porosity) had an effect on model predictions. Thus, the models were limited by the accuracy of the assumptions used to model flow and uncertainties associated with the available data to represent average properties of deposits and average nitrate- $\mathrm{N}$ loading to the aquifer. Furthermore, model predictions were based on a constant number of domestic wells and septic-tank systems for 50 years, and dynamic changes in groundwater pumping and use of septic systems were not evaluated.

The nitrate- $\mathrm{N}$ concentration of septic-system leakage is unlikely to be constant across the Carson Valley because of variability in hydraulic properties and biogeochemical processes that control transport in the unsaturated zone and the age and efficiency of septic systems. A conservative solute was introduced to the model to represent septic-system discharge with a concentration of $40 \mathrm{mg} / \mathrm{L}$. As shown in figure 25 , nitrate- $\mathrm{N}$ source concentrations beneath septictank systems can be highly variable, and these types of data are largely unknown for the Carson Valley area. Rosen and others (2006) found the source concentration to range from 1 to greater than $420 \mathrm{mg} / \mathrm{L}$ on the basis of measured data in Spanish Springs, Nevada, an environment similar to Carson Valley. The source concentration can change, and is dependent on, the number of occupants in a household (U.S. Environmental Protection Agency, 1980). In general, the more people who use a septic system, the more nitrogen will be contributed to the subsurface. The U.S. EPA reported mass loading and nitrate-N concentrations of 7-17 grams per person per day and $26-75 \mathrm{mg} / \mathrm{L}$, respectively, in typical wastewater effluent (U.S. Environmental Protection Agency, 2002). However, few of the U.S. EPA measurements were from arid environments, and the ranges reported by Rosen and others (2006) are likely to be more representative of conditions in Carson Valley. The concentration used in the predictive and hypothetical models represented the median nitrate- $\mathrm{N}$ concentration $(\mathrm{n}=96)$ obtained from lysimeter data beneath septic leach fields in Spanish Springs, Nevada (Rosen and others, 2006). This concentration also was consistent and within the range of another septic-tank solute transport study for New Washoe City, Nevada (Zhan and Mackay, 1998). Although cursory comparisons were made of the historic concentrations and change over time with the simulated concentrations for 2008-09, spatially distributed arrival time was unknown, and source concentrations data were not available to calibrate and refine hydraulic and transport properties of the VS2DT model. Therefore, the estimates of arrival time and source concentration could lead to predictive uncertainty that cannot be resolved without a rigorous field sampling campaign, which was beyond the scope of this effort.

Spatial variability of nitrate-N loading, septic-system density, and groundwater pumping had the greatest control on the distribution and transport of nitrate- $\mathrm{N}$ for the Carson Valley area. Given the scale of the modeling effort, drawdown from groundwater pumping and groundwater-recharge estimates were assumed to be consistent with the regional groundwater-flow model without rigorous recalibration of the flow and transport parameters. The models only were designed to provide approximations of the actual concentrations and transport of nitrate-N, given a generalized flow system for the evaluation of gross changes in the distribution and magnitude of concentrations for hypothetical changes in source (H1) and stresses (H2). In transient solute-transport simulations, error can be associated with timing, mass loading, groundwater-flow velocities, and inadequate estimation of the drawdown associated with pumping. The intent of this modeling effort was to simulate nitrate-N transport and evaluate different scenarios for managing septic-system usage.

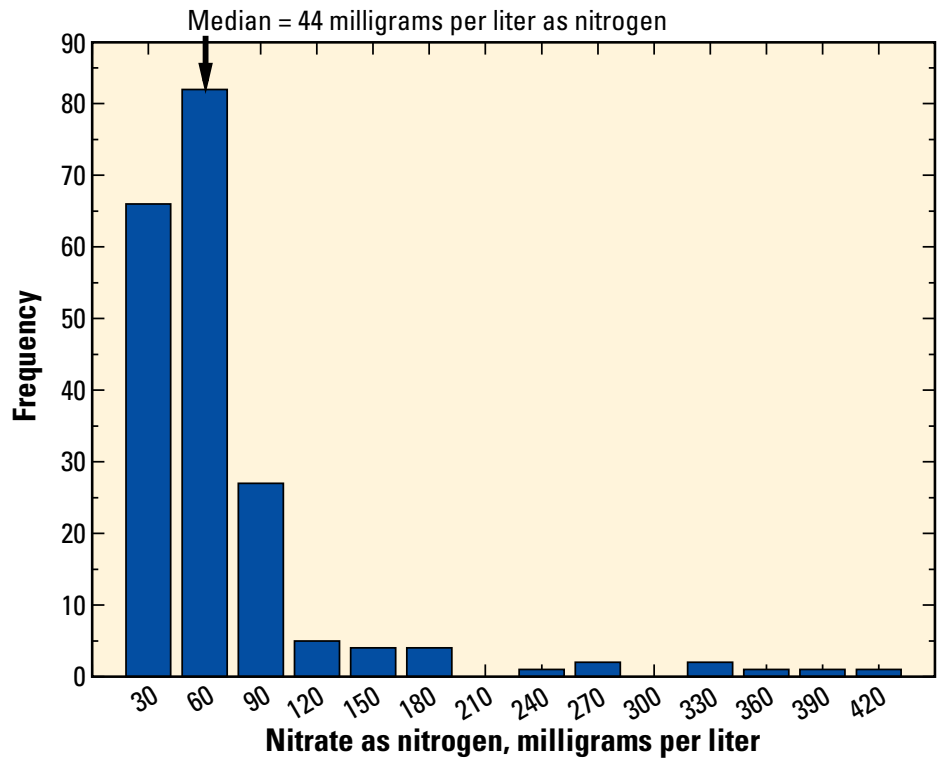

Figure 25. Nitrate as nitrogen concentration frequency plot for wells sampled in Spanish Springs, Washoe County, Nevada, 2008-09. 


\section{Summary and Conclusions}

Results from groundwater sampling and analysis of 179 wells (228 total samples) located in areas with different land uses throughout Carson Valley showed nitrate-N concentrations in the aquifer ranged from less than detection $(0.05 \mathrm{mg} / \mathrm{L})$ to greater than $18 \mathrm{mg} / \mathrm{L}$. Nitrate-N concentrations above the U.S. Environmental Protection Agency's maximum contaminant level of $10 \mathrm{mg} / \mathrm{L}$ were found in three wells $(0.2$ percent of wells sampled). Land-use analysis indicated that elevated nitrate- $\mathrm{N}$ concentrations were related to septic-system density, groundwater age, and residential, single-family land use. The positive correlation between septic-system density and nitrate- $\mathrm{N}$ concentration was consistent with previous studies (Rosen, 2003; Shipley and Rosen, 2005) that contained more limited data for Carson Valley. There was no statistical correlation between nitrate- $\mathrm{N}$ concentrations and agricultural or other land uses in the valley.

Background concentrations (wells sampled away from anthropogenic sources of nitrate-N) of nitrate-N in Carson Valley were generally less than $1 \mathrm{mg} / \mathrm{L}$. The mean nitrate- $\mathrm{N}$ concentration for the valley was $2.2 \mathrm{mg} / \mathrm{L}$, indicating that, in general, the nitrate- $\mathrm{N}$ concentration of the valley was elevated above background. In addition, several areas of the valley had mean nitrate- $\mathrm{N}$ concentrations greater than $4 \mathrm{mg} / \mathrm{L}$, and all of the areas with elevated mean nitrate- $\mathrm{N}$ were dependent on septic systems for wastewater disposal. Nitrate-N concentrations were also greater in wells less than 250 -ft below land surface, which indicated that the likely source was near the water table.

The results from nitrogen and oxygen isotope analyses showed a correlation between nitrate- $\mathrm{N}$ concentrations and $\delta^{15} \mathrm{~N}$ values. Groundwater samples with nitrate-N concentrations greater than $5 \mathrm{mg} / \mathrm{L}$ and $\delta^{15} \mathrm{~N}$ values greater than $7 \%$ were collocated in areas with a high density of septic systems in single-family residential areas. Nitrogen isotope values in this range indicate that animal and human waste was the main source of this nitrogen, although a lesser contribution of natural soil nitrate- $\mathrm{N}$ was possible. The relatively high dissolved oxygen concentration, low dissolved nitrogen gas, and high values of nitrogen isotopes indicated that the potential for reduction of nitrate-N through denitrification was limited. The nitrate-N concentrations could continue to increase under areas that receive additional inputs of nitrogen as a result of the low denitrification potential of the aquifer.

In general, age-dating of water from selected wells indicated that much of the water infiltrated between 1970 and 1995, although mixing with water that is older and younger than that period contributed to this range of ages. This indicated that nitrate-N contamination from septic systems could last for a long time after it enters the groundwater system (greater than 50 years).

The continued increase in nitrate- $\mathrm{N}$ concentrations based on samples collected from long-term trend wells located throughout Carson Valley indicated that increases in nitrate$\mathrm{N}$ was not limited to just the Ruhenstroth and Johnson Lane areas, but also could be of concern for other down-gradient areas in the valley where septic-system density is greater than one per 3 acres. The presence of high nitrate- $\mathrm{N}$ concentrations in some areas of the valley could be an indication that the dilution capacity of the aquifer has been exceeded, and further development should consider the cumulative effects of septicsystem use.

The numerical models used in the study are a representation of our conceptual understanding of the geochemical processes and the groundwater-flow system. The results of the transport model indicated that nitrate- $\mathrm{N}$ concentrations would continue to increase and transport away from source areas. The depth to groundwater and age of septic systems were directly related to the nitrate- $\mathrm{N}$ concentrations in the alluvial aquifer, and there was a time lag between the construction date of the septictank system and the arrival of nitrate- $\mathrm{N}$ to the aquifer. Thus, nitrate-N loading aquifer is expected to continue to rise into the future, and the magnitude of the groundwater nitrate- $\mathrm{N}$ concentrations is dependent on the proximity to groundwater pumping and the Carson River.

The hypothetical models used in this study indicated that the continual persistence of nitrate- $\mathrm{N}$ contamination in groundwater is a concern long after the removal or discontinuation of septic-system usage. However, if the septic-tank systems were no longer used (H1 scenario), groundwater nitrate-N concentrations would rapidly decrease within 30 years as a result of removal of mass through groundwater pumping. If septic-tank systems were no longer used and domestic pumping was terminated ( $\mathrm{H} 2$ scenario), groundwater nitrate- $\mathrm{N}$ concentrations would also decline, but at a slower rate. The results of the hypothetical scenarios indicated that nitrate- $\mathrm{N}$ transport in the alluvial aquifer was largely influenced by groundwater pumping, and usage for consumptive purposes should continue to be monitored into future. 


\section{References Cited}

Avery, A.A., 1999, Infantile methemoglobinemia-Reexamining the role of drinking water nitrates: Environmental Health Perspectives, v. 107, no. 7, p. 583-586.

Canter, L.W., and Knox, R.C., 1985, Septic system effects on groundwater quality: Chelsea, Michigan, Lewis Publishers, $336 \mathrm{p}$.

Comly, H.H., 1945, Cyanosis in infants caused by nitrates in well water: Journal of the American Medical Association, v. 29, p. 112-116.

Conan, C., Bouraoui, F., Turpin, N., de Marsily, G., and Bidoglio, G., 2003, Modeling flow and nitrate fate at catchment scale in Brittany, France: Journal of Environmental Quality, v. 32 , p. 2,026-2,032.

Dillingham, H.L, 1980, Washoe Project, Nevada-California, ground-water geology and resources, definite plan appendix, Carson Valley, Nevada: U.S. Bureau of Reclamation, Sacramento, California, $82 \mathrm{p}$.

Douglas County, 2006, Douglas County Building Division Septic Application: Accessed at http://nv-douglascounty. civicplus.com/DocumentCenter/Home/View/26.

Douglas County, Nevada, 2009, Assessor parcel search: Accessed at http://assessor.co.douglas.nv.us/database/2008/ parcel/index.asp.

Drever, J.I., 1997, The geochemistry of natural waters-Surface and groundwater environments ( $3 \mathrm{~d}$ ed.): Englewood Cliffs, New Jersey, Prentice-Hall, 436 p.

Freeze, R.A., and Cherry J.A., 1979, Groundwater: Englewood Cliffs, New Jersey, Prentice-Hall, 604 p.

Gelhar, L.W., Welty, C., Rehfeldt, K.R., 1992, A critical review of data on field-scale dispersion in aquifers: Water Resources Research, v. 28, p. 1955-1974.

Hantzche, N.N., and Finnemore, E.J., 2005, Predicting Ground-Water Nitrate-Nitrogen Impacts: Ground Water, v. 30, no. 4, p. $490-498$

Harbaugh, A.W., 2005, MODFLOW-2005, the U.S. Geological Survey modular groundwater model - the groundwater flow process: U.S. Geological Survey Techniques and Methods, book 6, chap. A16.

Healy, R.W., and Ronan, A.D., 1996, Documentation of computer program VS2DH for simulation of energy transport in variably saturated porous media-modification of the U.S. Geological Survey's computer program VS2DT: U.S. Geological Survey Water-Resources Investigations Report 96-4230, 36 p. An electronic version of this report can be downloaded from: http://pubs.er.usgs.gov/pubs/wri/ wri964230
Hem, J.D., 1992, The study and interpretation of the chemical characteristics of natural water (3d ed.): U.S. Geological Survey Water-Supply Paper 2254, 225 p.

Hill, M.J., Hawksworth, G., and Tattersall, G., 1973, Bacteria, nitrosamines and cancer of the stomach: British Journal of Cancer, v. 28, p. 562-567.

Hinkle, S.R., Shapiro, S.D., Plummer, L.N., Busenberg, E., Widman, P.K., Casile, G.C., and Wayland, J.E., 2010, Estimates of tracer-based piston-flow ages of groundwater from selected sites-National Water-Quality Assessment Program, 1992-2005: U.S. Geological Survey Scientific Investigations Report 2010-5229, 90 p.

Hsieh, P.A., Wingle, William, and Healy, R.W., 2000, VS2DI-A graphical software package for simulating fluid flow and solute or energy transport in variably saturated porous media: U.S. Geological Survey Water-Resources Investigations Report 99-4130, 16 p.

Kendall, C., 1998, Tracing nitrogen sources and cycling in catchments in Kendall, C., and McDonnell, J.J. (eds.), Isotope tracers in catchment hydrology: Amsterdam, Elsevier, p. 519-576.

Koterba, M.T, Wilde, F.D., and Lapham, W.W., 1995, Groundwater data-collection protocols and procedures for the National Water-Quality Assessment Program: Collection and documentation of water-quality samples and related data: U.S. Geological Survey Open-File Report 95-399, $113 \mathrm{p}$.

Lorenz, D.L., Ahearn, E.A., Carter, J.M., Cohn, T.A., Danchuk, W.J., Frey, J.W., Helsel, D.R., Lee, K.E., Leeth, D.C., Martin, J.D., McGuire, V.L., Neitzert, K.M., Robertson, D.M., Slack, J.R., Starn, J., Vecchia, A.V., Wilkison, D.H., and Williamson, J. E., 2011, USGS library for S-PLUS for Windows-Release 4.0: U.S. Geological Survey Open-File Report 2011-1130. http://water.usgs.gov/software/S-PLUS/.

MacQuarrie, K.T.B., Sudicky, E.A., and Robertson, W.D., 2001, Numerical simulation of a fine-grained denitrification layer for removing septic system nitrate from shallow groundwater: Journal of Contaminant Hydrology, v. 52, p. 29-55.

Makowski, Anna, 2006, Modeling nitrate transport in Spanish Springs Valley, Washoe County, Nevada: Reno, University of Nevada, M.S. thesis.

Malberg, J.W., Savage, E.P., and Osterhoung, J., 1978, Nitrates in drinking water and the early onset of hypertension: Environmental Pollution, v. 15, p. 155-160.

Maurer, D.K., 1984, Gravity survey and depth to bedrock in Carson Valley, Nevada-California: U.S. Geologic Survey Water-Resources Investigation Report 84-4202, 20 p. 
Maurer, D.K., 1986, Geohydrology and simulated response to ground-water pumpage in Carson Valley, a river-dominated basin in Douglas County, Nevada, and Alpine County, California: U.S. Geological Survey Water-Resources Investigations Report 86-4328, 109 p.

Maurer, D.K., and Berger, D.L., 2006, Water budgets and potential effects of land and water-use changes for Carson Valley, Douglas County, Nevada, and Alpine County, California: U.S. Geological Survey Scientific Investigations Report 2006-5305, 64 p.

Maurer, D.K., and Peltz, L.A., 1994, Potential for, and possible effects of, artificial recharge in Carson Valley, Douglas County, Nevada: U.S. Geological Survey Water-Resources Investigations Report 94-4126, 4 map sheets.

Miller, J.C., 1975, Nitrate contamination of the water-table aquifer by septic tank systems in the coastal plain of Delaware in Water Pollution Control in Low Density Areas: Proceedings of Rural Environmental Engineering Conference, Hanover, New Hampshire, September 1973, Jewell, W.S., and Swan, R., eds.: Hanover, New Hampshire, University Press of New England, p. 121-133.

Morgan, D.S., Hinkle, S.R., and Weick, R.J., 2007, Evaluation of approaches for managing nitrate loading from on-site wastewater systems near La Pine, Oregon: U.S. Geological Survey Scientific Investigations Report 2007-5237, 66 p.

Parslow, R.C., McKinney, P.A., Law, G.R., Staines, A., Williams, R., and Bodansky, H.J., 1997, Incidence of childhood diabetes mellitus in Yorkshire, northern England, is associated with nitrate in drinking water-An ecological analysis: Diabetologia, v. 40, p. 550-556.

Perkins, R.J., 1984, Septic system, lot size and pollution of water table aquifers: Journal of Environmental Health, v. 46 , p. $346-354$.

Reneau, R.B., Jr., Hagedorn, C., and Degen, M.J., 1989, Fate and transport of biological and inorganic contaminants from on-site disposal of domestic wastewater: Journal of Environmental Quality, v. 18, no. 2, p. 298-304.

Révész, Kinga, and Casciotti, Karen, 2007, Determination of the $\delta\left({ }^{15} \mathrm{~N} /{ }^{14} \mathrm{~N}\right)$ and $\delta\left({ }^{18} \mathrm{O} /{ }^{16} \mathrm{O}\right)$ of Nitrate in Water: RSIL Lab Code 2900, chap. C17 of Révész, Kinga, and Coplen, Tyler B., eds., Methods of the Reston Stable Isotope Laboratory: Reston, Virginia, U.S. Geological Survey, Techniques and Methods, book 10, sec. C, chap. 17, 24 p.

Rosen, M.R., 2003, Trends in nitrate and dissolved-solids concentrations in ground water, Carson Valley, Douglas County, Nevada, 1985-2001: U.S. Geological Survey Water Resources Investigations Report 03-4152, 6 p.
Rosen, M.R., Kropf, C., and Thomas, K.A., 2006, Quantification of the contribution of nitrogen from septic systems to ground water in Spanish Springs Valley, Nevada: U.S. Geological Survey Scientific Investigations Report 2006-5206, prepared in cooperation with Washoe County Department of Water Resources, Reno, Nevada, 12 p.

Shipley, D.O., and Rosen, M.R., 2005, Identification of nitrate and dissolved-solids sources in ground water by GIS analysis: Environmental Practice, v. 7, p. 32-43.

Sigman, D.M., Casciotti, K.L., Andreani, M., Barford, C., Galanter, M., and Böhlke, J.K, 2001, A Bacterial method for the nitrogen isotopic analysis of nitrate in seawater and freshwater: Analytical. Chemistry, v. 73 , no. 17, p. 4,1454,153 .

Silva, S.R., Kendall, C., Wilkison, D.H., Ziegler, A.C., Chang, C.C.Y., and Avanzino, R.J., 2000, A new method for collection of nitrate from fresh water and the analysis of nitrogen and oxygen isotope ratios: Journal of Hydrology, v. 21, p. 22-36.

State of Nevada, 2009, Mapping \& Data-Well log database query tool: Division of Water Resources, http://water.nv.gov/data/welllog/.

Super, M., Heese, H., Mackenzie, D., Dempster, W.S., duPless, J., and Ferreira, J.J., 1981, An epidemiologic study of well-water nitrates in a group of South West African Namnian infants: Water Resources, v. 15, p. 1,265-1,270.

Thodal, C.E. 1996. Trends in chloride, dissolved-solids, and nitrate concentrations in ground water, Carson Valley and Topaz Lake areas, Douglas County, Nevada, 1959-1988. U.S. Geological Survey Water-Resources Investigations Report 95-4254, $32 \mathrm{p}$.

Thomas, J.M., Thodal, C.E., and Seiler, R.L., 1999, Identification of nitrate sources contributing to ground water in the Indian Hills area of Douglas County, Nevada: U.S. Geological Survey Water-Resources Investigations Report 99-4042, $22 \mathrm{p}$.

U.S. Census Bureau, 2009, State and County Quick FactsDouglas County, Nevada: Accessed at http://quickfacts. census.gov/qfd/states/32/32005lk.html.

U.S. Environmental Protection Agency, 1980, Onsite wastewater treatment and disposal systems design manual: Cincinnati, Ohio, EPA-625/1-80-012, 391 p.

U.S. Environmental Protection Agency, 2002, Onsite wastewater treatment systems manual, U.S. Environmental Protection Agency, Office of Water, EPA600/R-00/008.

U.S. Geological Survey, 2008a, CFC sampling methodbottles: Chloroflourocarbon Laboratory, accessed at http:// water.usgs.gov/lab/chlorofluorocarbons/sampling/bottles/. 
U.S. Geological Survey, 2008b, Dissolved gas sampling instructions: Accessed at http://water.usgs.gov/lab/dissolved-gas/sampling/.

University of Miami, 2009, The Tritium Laboratory: Rosenstiel School of Marine and Atmospheric Science, accessed

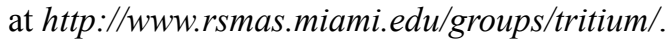

Walvoord, M.A., Phillips, F.M., Stonestrom, D.A., Evans, R.D., Hartsough, P.C., Newman, B.D., and Striegl, R.G., 2003, A reservoir of nitrate beneath desert soils: Science, v. 302, no. 7, p. 1,021-1,024.

Ward, M.H., deKok, T.M., Levallois, P., Brender, J., Gulis, G., Nolan, B.T., and VanDerslice, J., 2005, Workgroup Report: Drinking-water nitrate and health-recent findings and research needs: Environmental Health Perspectives, v. 113, no. 11, p. 1,607-1,614.

Western Regional Climate Center, 2006, Historic Climate Information: Accessed at http://www.wrcc.dri.edu/.

Williams, A.E., Lund, L.J., Johnson, J.A., and Kabala, Z.J., 1998, Natural and anthropogenic nitrate contamination of groundwater in a rural community, California: Environmental Science and Technology, v. 32, no. 1, p. 32-39.

Winston, R.B., 2009, ModelMuse-A graphical user interface for MODFLOW-2005 and PHAST: U.S. Geological Survey Techniques and Methods, book 6, chap. A29, 52 p.

Yager, R.M., Maurer, D.K., and Mayers, C.J., 2012, Assessing potential effects of changes in water use with a numerical groundwater-flow model of Carson Valley, Douglas County, Nevada, and Alpine County, California: U.S. Geological Survey Scientific Investigations Report 2012-5262, 73 p.

Yates, M.V., 1985, Septic system density and ground-water contamination: Ground Water, v. 23, p. 586-591.

Zhan, H. and W.A. Mckay, 1998, An assessment of nitrate occurrence and transport in Washoe Valley, Nevada: Environmental \& Engineering Geoscience, vol. 4, no. 4, p. $479-489$.

Zheng, C., and Wang, P.P., 1999, MT3DMS, A modular threedimensional multi-species transport model for simulation of advection, dispersion and chemical reactions of contaminants in groundwater systems; documentation and user's guide, Vicksburg, Miss., U.S. Army Engineer Research and Development Center Contract Report SERDP-99-1, 202 p. 
Appendix 1. Field, nutrient, chloride, and bromide chemical data, and land use and number of septic tanks within 500 meters of each well. [Data from station number in bold comes from other sources and is not included in the USGS NWIS database system. USGS, U.S. Geological Survey; NWIS, National Water Information System; mm/dd/yyy, month/day/year; NAD83, North American Datum of 1983; mg/L, milligrams per liter; $\mu \mathrm{S} / \mathrm{cm}$, microsiemens per centimeter; —, no data; E, estimate; <, less than; $\mathrm{M}$, presence of material verified but not quantified]

\begin{tabular}{|c|c|c|c|c|c|c|c|c|c|c|}
\hline Station number & Station name & $\begin{array}{c}\text { Date } \\
\text { (mm/dd//yyy) }\end{array}$ & Round & $\begin{array}{l}\text { Latitude-longitude } \\
\text { (NAD83) }\end{array}$ & $\begin{array}{c}\text { Well } \\
\text { depth, } \\
\text { (feet) }\end{array}$ & $\begin{array}{c}\text { pH, water, } \\
\text { unfiltered, } \\
\text { field, } \\
\text { (standard } \\
\text { units) }\end{array}$ & $\begin{array}{c}\text { Dissolved } \\
\text { oxygen, } \\
\text { water, } \\
\text { unfiltered, } \\
\text { (mg/L) }\end{array}$ & $\begin{array}{c}\text { Specific } \\
\text { conductance, } \\
\text { water, } \\
\text { unfiltered, } \\
(\mu \mathrm{S} / \mathrm{cm})\end{array}$ & $\begin{array}{c}\text { Tempera- } \\
\text { ture, water, } \\
\text { (degrees } \\
\text { Celsius) }\end{array}$ & $\begin{array}{c}\text { Nitrate, wa- } \\
\text { ter, filtered, } \\
\text { field, (mg/L as } \\
\text { nitrogen) }\end{array}$ \\
\hline 385801119421501 & 105 N13 E20 26ABBB1 & $5 / 1 / 2008$ & Round 1 & $385807 \mathrm{~N} 1194221 \mathrm{~W}$ & 130 & 7.4 & - & 284 & 14.7 & - \\
\hline 390055119421901 & 105 N13 E20 02CDAB1 & $8 / 25 / 2008$ & Round 1 & $390054 \mathrm{~N} 1194222 \mathrm{~W}$ & 350 & 8.3 & 0.4 & 327 & 24.5 & - \\
\hline 385509119414801 & 105 N12 E20 11ADD 1 & $8 / 27 / 2008$ & Round 1 & $385509 \mathrm{~N} 1194114 \mathrm{~W}$ & 125 & 7.6 & 8.2 & 522 & 14.8 & 7.47 \\
\hline 385654119431801 & 105 N13 E20 34ACC 1 & $8 / 27 / 2008$ & Round 1 & $385652 \mathrm{~N} 1194332 \mathrm{~W}$ & 80 & 7.4 & 7.5 & 503 & 15.2 & 3.22 \\
\hline 385801119421501 & 105 N13 E20 26ABBB1 & $8 / 27 / 2008$ & Round 1 & $385807 \mathrm{~N} 1194221 \mathrm{~W}$ & 130 & 7.3 & 6.3 & 313 & 15.8 & 2.43 \\
\hline 390446119451401 & $\begin{array}{l}105 \text { N14 E20 17ADCA1 } \\
\text { Wetlands } 5\end{array}$ & $8 / 28 / 2008$ & Round 1 & $390445 \mathrm{~N} 1194551 \mathrm{~W}$ & 27 & 6.7 & 0.9 & 3220 & 15.3 & 0 \\
\hline 390021119504301 & 105 N13 E19 09ADCA1 & $9 / 3 / 2008$ & Round 1 & $390022 \mathrm{~N} 1195005 \mathrm{~W}$ & 180 & 7.3 & 7 & 291 & 13.9 & 0.84 \\
\hline 390457119491301 & 105 N14 E19 14BBD 1 & $9 / 3 / 2008$ & Round 1 & $390456 \mathrm{~N} 1194992 \mathrm{~W}$ & 100 & 8.6 & 6.5 & 129 & 15.2 & 2.6 \\
\hline 390542119472001 & 105 N14 E19 12ADAB1 & $9 / 3 / 2008$ & Round 1 & $390541 \mathrm{~N} 1194772 \mathrm{~W}$ & 155 & 8 & 4.4 & 251 & 15.9 & 2.68 \\
\hline 385255119482301 & 105 N12 E19 23DDD 1 & $9 / 4 / 2008$ & Round 1 & $385254 \mathrm{~N} 1194883 \mathrm{~W}$ & 141 & 8.8 & 5.8 & 111 & 15.1 & 0.4 \\
\hline 385340119403601 & 105 N12 E20 24AAAA1 & $9 / 4 / 2008$ & Round 1 & $385340 \mathrm{~N} 1194003 \mathrm{~W}$ & 195 & 7.8 & 9.8 & 407 & 14.6 & 3.97 \\
\hline 385321119405002 & 105 N12 E20 24ADCC2 & $9 / 8 / 2008$ & Round 1 & $385319 \mathrm{~N} 1194005 \mathrm{~W}$ & 145 & 7.7 & 7 & 475 & 15 & 6.41 \\
\hline 385424119494401 & 105 N12 E19 15ADBB1 & $9 / 8 / 2008$ & Round 1 & $385424 \mathrm{~N} 1194994 \mathrm{~W}$ & 183 & 7.1 & 7.5 & 74 & 11.3 & 0.43 \\
\hline 385441119495501 & 105 N12 E19 10DCDB1 & $9 / 8 / 2008$ & Round 1 & $385442 \mathrm{~N} 1194995 \mathrm{~W}$ & 107 & 6.3 & 7.5 & 110 & 12.1 & - \\
\hline 385530119501501 & 105 N12 E19 03CDCB1 & $9 / 8 / 2008$ & Round 1 & $385536 \mathrm{~N} 1195001 \mathrm{~W}$ & 112 & 7 & 7.6 & 124 & 12 & 1.49 \\
\hline 385423119494301 & 105 N12 E19 15ADBB2 & $9 / 8 / 2008$ & Round 1 & $385423 \mathrm{~N} 1194994 \mathrm{~W}$ & - & 6.6 & 8.6 & 83 & 12 & 1.07 \\
\hline 390230119440301 & 105 N14 E20 28DDDC1 & $11 / 3 / 2008$ & Round 1 & $390230 \mathrm{~N} 1194440 \mathrm{~W}$ & - & 7.9 & 3.6 & 356 & 15.2 & 0.7 \\
\hline 390144119441701 & 105 N14 E20 33DCAD1 & $11 / 3 / 2008$ & Round 1 & $390143 \mathrm{~N} 1194441 \mathrm{~W}$ & - & 8.3 & 4.2 & 215 & 14 & 1.6 \\
\hline 390145119430101 & 105 N14 E20 34DDAC1 & $11 / 3 / 2008$ & Round 1 & $390143 \mathrm{~N} 1194330 \mathrm{~W}$ & 240 & 7.7 & 2.2 & 293 & 16.4 & 0.7 \\
\hline 385927119474601 & 105 N13 E19 13ACC 1 & $11 / 10 / 2008$ & Round 1 & $385926 \mathrm{~N} 1194774 \mathrm{~W}$ & 150 & 7.8 & 0.6 & 394 & 12.4 & 0.8 \\
\hline 385925119474001 & 105 N13 E19 13ACDC1 & $11 / 10 / 2008$ & Round 1 & $385925 \mathrm{~N} 1194773 \mathrm{~W}$ & - & 8 & - & 442 & 9.3 & 1.2 \\
\hline 385543119495001 & 105 N12 E19 03DBCD1 & $11 / 10 / 2008$ & Round 1 & $385543 \mathrm{~N} 1194995 \mathrm{~W}$ & 200 & 6.8 & 5.6 & 42 & 9.4 & 0.2 \\
\hline 390208119433201 & 105 N14 E20 34BDBD1 & $11 / 17 / 2008$ & Round 1 & $390207 \mathrm{~N} 1194333 \mathrm{~W}$ & 100 & 7.4 & 4.2 & 430 & 16.6 & 5.72 \\
\hline 390257119471001 & 105 N14 E20 30BCCD1 & $11 / 17 / 2008$ & Round 1 & $390257 \mathrm{~N} 1194770 \mathrm{~W}$ & 400 & 8.4 & 0.1 & 104 & 16.1 & 0.5 \\
\hline 390025119503101 & 105 N13 E19 10BCBD1 & $11 / 21 / 2008$ & Round 1 & $390025 \mathrm{~N} 1195003 \mathrm{~W}$ & 180 & 6.3 & 4.5 & 131 & 12.1 & 1.1 \\
\hline 385154119461101 & 105 N12 E20 32AADA1 & $11 / 21 / 2008$ & Round 1 & $385153 \mathrm{~N} 1194661 \mathrm{~W}$ & 260 & 7.2 & 1.1 & 112 & 13.1 & 0.1 \\
\hline 390239119453901 & 105 N14 E20 29DCBB1 & $11 / 21 / 2008$ & Round 1 & $390238 \mathrm{~N} 1194553 \mathrm{~W}$ & 123 & 7.5 & 0.5 & 532 & 13.8 & 0.4 \\
\hline 390018119485801 & 105 N13 E19 11BDD 1 & $11 / 24 / 2008$ & Round 1 & $390018 \mathrm{~N} 1194885 \mathrm{~W}$ & 216.2 & 8.4 & 0.4 & 87 & 13.6 & 0.3 \\
\hline 390011119480901 & 105 N13 E19 12CBA 1 & $11 / 24 / 2008$ & Round 1 & $390011 \mathrm{~N} 1194880 \mathrm{~W}$ & - & 8 & 3.1 & 64 & 12.4 & 0.3 \\
\hline 390021119504301 & 105 N13 E19 09ADCA1 & $11 / 24 / 2008$ & Round 1 & $390022 \mathrm{~N} 1195005 \mathrm{~W}$ & 180 & 7.4 & 6.5 & 291 & 13.9 & 0.51 \\
\hline 385744119423901 & $\begin{array}{l}105 \text { N13 E20 26BCAC1 } \\
\text { Eastside Memorial Park }\end{array}$ & $11 / 28 / 2008$ & Round 1 & $385743 \mathrm{~N} 1194224 \mathrm{~W}$ & - & 8 & 5 & 137 & 19.8 & 0.3 \\
\hline 390045119453801 & 105 N13 E20 05CDD 1 & $11 / 28 / 2008$ & Round 1 & $390045 \mathrm{~N} 1194553 \mathrm{~W}$ & 298 & 8.3 & 0.3 & 312 & 13.5 & 0.41 \\
\hline
\end{tabular}


Appendix 1. Field, nutrient, chloride, and bromide chemical data, and land use and number of septic tanks within 500 meters of each well.-Continued [Data from station number in bold comes from other sources and is not included in the USGS NWIS database system. USGS, U.S. Geological Survey; NWIS, National Water Information System; m/dd/yyy, month/day/year; NAD83, North American Datum of 1983; mg/L, milligrams per liter; —, no data; E, estimate; <, less than; M, presence of material verified

but not quantified]

\begin{tabular}{|c|c|c|c|c|c|c|c|c|c|c|c|c|c|c|}
\hline Station number & $\begin{array}{c}\text { Chloride, } \\
\text { water, fil- } \\
\text { tered, field, } \\
\text { (mg/L) }\end{array}$ & $\begin{array}{l}\text { Chloride, } \\
\text { water, } \\
\text { filtered, } \\
\text { (mg/L) }\end{array}$ & $\begin{array}{l}\text { Nitrate plus } \\
\text { nitrite, wa- } \\
\text { ter, filtered, } \\
\text { (mg/L as } \\
\text { nitrogen) }\end{array}$ & $\begin{array}{l}\text { Bromide, } \\
\text { water, } \\
\text { filtered, } \\
\text { (mg/L) }\end{array}$ & $\begin{array}{l}\text { Ammonia, } \\
\text { water, } \\
\text { filtered, } \\
\text { (mg/L as } \\
\text { nitrogen) }\end{array}$ & $\begin{array}{c}\text { Commercial, } \\
\text { (percent) }\end{array}$ & $\begin{array}{l}\text { Industrial, } \\
\text { (percent) }\end{array}$ & $\begin{array}{c}\text { Multi- } \\
\text { residential, } \\
\text { (percent) }\end{array}$ & $\begin{array}{c}\text { Residential } \\
\text { single } \\
\text { family, } \\
\text { (percent) }\end{array}$ & $\begin{array}{c}\text { Rural, } \\
\text { (percent) }\end{array}$ & $\begin{array}{c}\begin{array}{c}\text { Unclassi- } \\
\text { fied, } \\
\text { (percent) }\end{array}\end{array}$ & $\begin{array}{l}\text { Utilities, } \\
\text { (percent) }\end{array}$ & $\begin{array}{c}\text { Vacant } \\
\text { land, } \\
\text { (percent) }\end{array}$ & $\begin{array}{l}\text { Number } \\
\text { of } \\
\text { septic } \\
\text { tanks }\end{array}$ \\
\hline 385801119421501 & - & 5.53 & 1.57 & - & $<.020$ & 0.00 & 0.00 & 15.34 & 3.96 & 5.10 & 6.79 & 0.00 & 68.81 & 8 \\
\hline 390055119421901 & - & 11 & $<.016$ & - & 0.23 & 0.00 & 0.00 & 4.40 & 67.98 & 8.42 & 6.33 & 0.00 & 12.87 & 54 \\
\hline 385509119414801 & 37.19 & 22.8 & 6.81 & 0.21 & $<.020$ & 3.65 & 14.89 & 2.26 & 53.25 & 0.00 & 9.08 & 0.00 & 16.88 & 70 \\
\hline 385654119431801 & 16.26 & 10.5 & 2.27 & 0.06 & $<.020$ & 0.00 & 0.00 & 0.00 & 51.81 & 33.86 & 2.18 & 0.00 & 12.15 & 25 \\
\hline 385801119421501 & 7.24 & 5.4 & 1.44 & 0.04 & $<.020$ & 0.00 & 0.00 & 15.34 & 3.96 & 5.10 & 6.79 & 0.00 & 68.81 & 8 \\
\hline 390446119451401 & 429.05 & 238 & $<.016$ & 0.7 & 0.119 & 0.00 & 0.00 & 0.00 & 0.00 & 33.34 & 2.12 & 64.54 & 0.00 & 0 \\
\hline 390021119504301 & 1.8 & 1.58 & 0.408 & $<.02$ & $<.020$ & 2.16 & 0.00 & 4.33 & 55.66 & 0.00 & 8.09 & 0.00 & 29.75 & 84 \\
\hline 390457119491301 & 1.59 & 1.38 & 1.41 & - & $<.020$ & 0.00 & 0.00 & 1.02 & 37.73 & 49.63 & 4.93 & 0.00 & 6.69 & 45 \\
\hline 390542119472001 & 8.96 & 8.02 & 1.99 & 0.06 & $<.020$ & 6.20 & 0.00 & 1.70 & 59.24 & 0.00 & 11.30 & 7.17 & 14.40 & 103 \\
\hline 385255119482301 & 1.42 & 0.99 & 0.045 & $<.02$ & $<.020$ & 0.00 & 0.00 & 0.00 & 41.97 & 52.56 & 2.62 & 0.00 & 2.85 & 16 \\
\hline 385340119403601 & 19.05 & 14.1 & 2.94 & 0.12 & $<.020$ & 0.65 & 0.00 & 2.58 & 73.76 & 0.00 & 8.80 & 0.00 & 14.21 & 97 \\
\hline 385321119405002 & 33.67 & 21.7 & 5.02 & 0.14 & $<.020$ & 0.00 & 0.00 & 4.62 & 90.39 & 0.00 & 0.00 & 0.00 & 4.99 & 141 \\
\hline 385424119494401 & 0.54 & 0.27 & 0.18 & $<.02$ & $<.020$ & 1.40 & 0.00 & 1.53 & 67.83 & 6.62 & 11.12 & 0.00 & 11.52 & 107 \\
\hline 385441119495501 & - & 1 & 1.45 & $<.02$ & $<.020$ & 1.40 & 0.00 & 0.00 & 45.29 & 44.15 & 8.25 & 0.00 & 0.91 & 62 \\
\hline 385530119501501 & 1.47 & 1.21 & 1.17 & Е.01 & $<.020$ & 0.00 & 0.00 & 7.01 & 61.32 & 11.25 & 11.56 & 0.00 & 8.85 & 94 \\
\hline 385423119494301 & 0.98 & 0.49 & 0.67 & $<.02$ & $<.020$ & 1.40 & 0.00 & 1.65 & 65.79 & 5.50 & 11.43 & 0.00 & 14.24 & 110 \\
\hline 390230119440301 & 11.8 & - & - & 0.1 & - & 0.00 & 0.00 & 1.36 & 77.37 & 0.00 & 9.49 & 0.00 & 11.78 & 156 \\
\hline 390144119441701 & 10.8 & - & - & 0.1 & - & 0.52 & 0.00 & 1.57 & 61.98 & 19.74 & 11.80 & 0.00 & 4.39 & 111 \\
\hline 390145119430101 & 6.32 & 7.26 & 0.962 & 0.07 & $<.020$ & 2.59 & 0.00 & 9.55 & 67.08 & 4.89 & 12.93 & 0.90 & 2.06 & 123 \\
\hline 385927119474601 & 6.9 & - & - & 0.1 & - & 0.00 & 0.00 & 0.00 & 13.24 & 86.76 & 0.00 & 0.00 & 0.00 & 1 \\
\hline 385925119474001 & 8.74 & - & - & 0.1 & - & 0.00 & 0.00 & 0.00 & 11.30 & 88.70 & 0.00 & 0.00 & 0.00 & 1 \\
\hline 385543119495001 & 0.59 & - & - & $\mathrm{M}$ & - & 0.00 & 0.00 & 15.32 & 22.68 & 54.69 & 2.62 & 0.00 & 4.69 & 20 \\
\hline 390208119433201 & 33.98 & 23.4 & 4.41 & 0.18 & $<.020$ & 0.62 & 0.00 & 1.75 & 83.52 & 0.00 & 0.00 & 0.00 & 14.10 & 117 \\
\hline 390257119471001 & 4.07 & - & - & - & - & 0.00 & 0.00 & 16.50 & 9.54 & 0.00 & 3.37 & 0.00 & 70.59 & 3 \\
\hline 390025119503101 & 1.84 & - & - & 0.2 & - & 1.45 & 0.00 & 11.62 & 63.39 & 0.52 & 0.00 & 0.00 & 23.02 & 95 \\
\hline 385154119461101 & 1.71 & - & - & 0.2 & - & 0.00 & 0.00 & 0.00 & 0.00 & 100.00 & 0.00 & 0.00 & 0.00 & 5 \\
\hline 390239119453901 & 61.6 & - & - & - & - & 5.23 & 0.00 & 5.01 & 67.70 & 0.01 & 10.65 & 0.00 & 11.41 & 4 \\
\hline 390018119485801 & 1.6 & - & - & 0.2 & - & 0.00 & 0.00 & 0.01 & 3.34 & 76.28 & 0.80 & 0.00 & 19.57 & 5 \\
\hline 390011119480901 & 0.75 & - & - & 0.2 & - & 0.00 & 0.00 & 0.00 & 0.00 & 100.00 & 0.00 & 0.00 & 0.00 & 1 \\
\hline 390021119504301 & 1.73 & - & - & $<.05$ & $<.02$ & 2.16 & 0.00 & 4.33 & 55.66 & 0.00 & 8.09 & 0.00 & 29.75 & 84 \\
\hline 385744119423901 & 2.31 & - & - & $<.1$ & - & 0.00 & 0.00 & 13.13 & 31.02 & 10.25 & 3.94 & 9.92 & 31.74 & 25 \\
\hline 390045119453801 & 44.1 & 36.8 & $<.016$ & 0.17 & 0.055 & 0.71 & 4.82 & 0.00 & 0.00 & 53.28 & 4.29 & 0.00 & 36.90 & 2 \\
\hline
\end{tabular}


Appendix 1. Field, nutrient, chloride, and bromide chemical data, and land use and number of septic tanks within 500 meters of each well.-Continued [Data from station number in bold comes from other sources and is not included in the USGS NWIS database system. USGS, U.S. Geological Survey; NWIS, National Water Information System; mm/dd/yyy, month/day/year; NAD83, North American Datum of 1983; mg/L, milligrams per liter; $\mu \mathrm{S} / \mathrm{cm}$, microsiemens per centimeter; —, no data; E, estimate; <, less than; $M$, presence of material verified but not quantified]

\begin{tabular}{|c|c|c|c|c|c|c|c|c|c|c|}
\hline Station number & Station name & $\begin{array}{c}\text { Date } \\
\text { (mm/dd/yyyy) }\end{array}$ & Round & $\begin{array}{l}\text { Latitude-longitude } \\
\text { (NAD83) }\end{array}$ & $\begin{array}{c}\text { Well } \\
\text { depth, } \\
\text { (feet) }\end{array}$ & $\begin{array}{c}\text { pH, water, } \\
\text { unfiltered, } \\
\text { field, } \\
\text { (standard } \\
\text { units) }\end{array}$ & $\begin{array}{c}\text { Dissolved } \\
\text { oxygen, } \\
\text { water, } \\
\text { unfiltered, } \\
\text { (mg/L) }\end{array}$ & $\begin{array}{c}\text { Specific } \\
\text { conductance, } \\
\text { water, } \\
\text { unfiltered, } \\
(\mu \mathrm{S} / \mathrm{cm})\end{array}$ & $\begin{array}{c}\text { Tempera- } \\
\text { ture, water, } \\
\text { (degrees } \\
\text { Celsius) }\end{array}$ & $\begin{array}{c}\text { Nitrate, wa- } \\
\text { ter, filtered, } \\
\text { field, (mg/L as } \\
\text { nitrogen) }\end{array}$ \\
\hline 385605119381801 & 105 N12 E21 04BCAC1 & $12 / 2 / 2008$ & Round 1 & $385604 \mathrm{~N} 1193881 \mathrm{~W}$ & 120 & 7.8 & 5.6 & 212 & 12.7 & 1.1 \\
\hline 385610119415001 & 105 N12 E20 02AADC1 & $12 / 2 / 2008$ & Round 1 & $385610 \mathrm{~N} 1194114 \mathrm{~W}$ & 275 & 8.4 & 5.5 & 160 & 16.8 & 0.6 \\
\hline 390542119472001 & 105 N14 E19 12ADAB1 & $12 / 3 / 2008$ & Round 1 & $390541 \mathrm{~N} 1194772 \mathrm{~W}$ & 155 & 8 & 4.4 & 251 & 15.9 & 2 \\
\hline 385654119431801 & 105 N13 E20 34ACC 1 & $12 / 3 / 2008$ & Round 1 & $385652 \mathrm{~N} 1194332 \mathrm{~W}$ & 80 & 7.5 & 7.5 & 503 & 12 & 2.3 \\
\hline 390457119491301 & 105 N14 E19 14BBD 1 & $12 / 3 / 2008$ & Round 1 & $390456 \mathrm{~N} 1194992 \mathrm{~W}$ & 100 & 8.6 & 6.5 & 129 & 15.2 & 1.4 \\
\hline 385335119453501 & 105 N12 E20 20BDDD1 & $12 / 5 / 2008$ & Round 1 & $385335 \mathrm{~N} 1194553 \mathrm{~W}$ & 142 & 7.2 & 6.5 & 144 & 13.2 & 3 \\
\hline 385106119462601 & 105 N11 E20 06AABB1 & $12 / 5 / 2008$ & Round 1 & $385106 \mathrm{~N} 1194662 \mathrm{~W}$ & 200 & 6.3 & 1.6 & 74 & 12.6 & 1 \\
\hline 390138119434201 & 105 N14 E20 34CDCC2 & $12 / 8 / 2008$ & Round 1 & $390138 \mathrm{~N} 1194334 \mathrm{~W}$ & 115 & 7.9 & 7.2 & 228 & 15 & 2.9 \\
\hline 385339119490501 & 105 N12 E19 23BACA1 & $12 / 9 / 2008$ & Round 1 & $385339 \mathrm{~N} 1194990 \mathrm{~W}$ & - & 5.9 & & 97 & - & - \\
\hline 390010119504101 & 105 N13 E19 09DAAC3 & $12 / 9 / 2008$ & Round 1 & $390010 \mathrm{~N} 1195004 \mathrm{~W}$ & - & 6.6 & 7.3 & 98 & 9.2 & 0.3 \\
\hline 390015119500101 & 105 N13 E19 10DBB 1 & $12 / 9 / 2008$ & Round 1 & $390020 \mathrm{~N} 1195000 \mathrm{~W}$ & 115 & 7.3 & 3.8 & 209 & 12.5 & 1.7 \\
\hline 385843119450501 & 105 N13 E20 21BCBB1 & $12 / 10 / 2008$ & Round 1 & $385843 \mathrm{~N} 1194505 \mathrm{~W}$ & - & - & - & - & - & - \\
\hline 385927119451301 & $\begin{array}{l}105 \text { N13 E20 17ADDC1 } \\
\text { USGS AIR S }\end{array}$ & $12 / 10 / 2008$ & Round 1 & $385927 \mathrm{~N} 1194513 \mathrm{~W}$ & - & - & - & - & - & - \\
\hline 385921119425101 & 105 N13 E20 14CBBC1 & $12 / 10 / 2008$ & Round 1 & $385921 \mathrm{~N} 1194251 \mathrm{~W}$ & - & - & - & - & - & - \\
\hline 390041119424001 & 105 N13 E20 11BBAB1 & $12 / 10 / 2008$ & Round 1 & $390041 \mathrm{~N} 1194240 \mathrm{~W}$ & - & - & - & - & - & - \\
\hline 390115119441601 & 105 N13 E20 04ADCB1 & $12 / 10 / 2008$ & Round 1 & $390115 \mathrm{~N} 1194416 \mathrm{~W}$ & - & - & - & - & - & - \\
\hline 385604119435601 & $\begin{array}{l}105 \text { N12 E20 4ADA } 1 \\
\text { Town of Gardnerville } 6\end{array}$ & $12 / 15 / 2008$ & Round 1 & $385604 \mathrm{~N} 1194335 \mathrm{~W}$ & 300 & - & 2.1 & - & 11.9 & 2 \\
\hline 385444119453301 & 105 N12 E20 08DCCA1 & $12 / 15 / 2008$ & Round 1 & $385444 \mathrm{~N} 1194553 \mathrm{~W}$ & 390 & - & 6.7 & - & 15 & 2.6 \\
\hline 385751119470001 & $\begin{array}{l}105 \text { N13 E20 30BDBB1 } \\
\text { MINDEN NO } 4\end{array}$ & $12 / 16 / 2008$ & Round 1 & $385750 \mathrm{~N} 1194665 \mathrm{~W}$ & 360 & - & 1.9 & - & 14.1 & 0.7 \\
\hline 385742119453801 & 105 N13 E20 29BDDD1 & $12 / 16 / 2008$ & Round 1 & $385742 \mathrm{~N} 1194553 \mathrm{~W}$ & 118 & - & 2.3 & - & 12.9 & 1.6 \\
\hline 385652119471401 & 105 N13 E20 31BCC 1 & $12 / 16 / 2008$ & Round 1 & $385652 \mathrm{~N} 1194771 \mathrm{~W}$ & - & - & 3.2 & - & 14.9 & 0.4 \\
\hline 385441119485201 & 105 N12 E19 11DCC 1 & $12 / 17 / 2008$ & Round 1 & $385441 \mathrm{~N} 1194885 \mathrm{~W}$ & 148 & - & 7.5 & - & 9.6 & 0.9 \\
\hline 385604119392301 & 105 N12 E21 05BCDB1 & $12 / 19 / 2008$ & Round 1 & $385603 \mathrm{~N} 1193992 \mathrm{~W}$ & - & 9.6 & 4.6 & 157 & 18.3 & 1.2 \\
\hline 385821119502201 & 105 N13 E19 22CBDD1 & $12 / 19 / 2008$ & Round 1 & $385821 \mathrm{~N} 1195002 \mathrm{~W}$ & 150 & 7.8 & 0.8 & 312 & 12.8 & 0.3 \\
\hline 385612119470901 & 105 N12 E20 06BBDC1 & $12 / 19 / 2008$ & Round 1 & $385611 \mathrm{~N} 1194770 \mathrm{~W}$ & - & 7.4 & 2.3 & 171 & 11.8 & 3.8 \\
\hline 390222119462401 & 105 N14 E20 31AAC 1 & $12 / 21 / 2008$ & Round 1 & $390222 \mathrm{~N} 1194662 \mathrm{~W}$ & - & 7.8 & 0.2 & 121 & 12.4 & M \\
\hline 385639119413701 & 105 N13 E20 36CBCA1 & $1 / 7 / 2009$ & Round 1 & $385639 \mathrm{~N} 1194113 \mathrm{~W}$ & 260 & 7.3 & 2.1 & 201 & 13.7 & 1.2 \\
\hline 385641119391101 & 105 N13 E21 32CACA1 & $1 / 7 / 2009$ & Round 1 & $385641 \mathrm{~N} 1193991 \mathrm{~W}$ & 90 & 7.6 & 2.6 & 252 & 10.4 & 0.5 \\
\hline 385307119412201 & 105 N12 E20 24CACD1 & $1 / 8 / 2009$ & Round 1 & $385307 \mathrm{~N} 1194112 \mathrm{~W}$ & 180 & 8.1 & 2.4 & 201 & 13.1 & 2.2 \\
\hline 385326119411401 & 105 N12 E20 24BDAD1 & $1 / 8 / 2009$ & Round 1 & $385326 \mathrm{~N} 1194111 \mathrm{~W}$ & 200 & 7 & 6.4 & 372 & 12.7 & 4.4 \\
\hline 385714119384501 & 105 N13 E21 32ABAA1 & $1 / 8 / 2009$ & Round 1 & $385713 \mathrm{~N} 1193884 \mathrm{~W}$ & 117 & 8 & 0.3 & 210 & 12.8 & 0.1 \\
\hline
\end{tabular}


Appendix 1. Field, nutrient, chloride, and bromide chemical data, and land use and number of septic tanks within 500 meters of each well.-Continued [Data from station number in bold comes from other sources and is not included in the USGS NWIS database system. USGS, U.S. Geological Survey; NWIS, National Water Information System; m/dd/yyy, month/day/year; NAD83, North American Datum of 1983; mg/L, milligrams per liter; —, no data; E, estimate; <, less than; M, presence of material verified but not quantified]

\begin{tabular}{|c|c|c|c|c|c|c|c|c|c|c|c|c|c|c|}
\hline Station number & $\begin{array}{l}\text { Chloride, } \\
\text { water, fil- } \\
\text { tered, field, } \\
(\mathrm{mg} / \mathrm{L})\end{array}$ & $\begin{array}{l}\text { Chloride, } \\
\text { water, } \\
\text { filtered, } \\
\text { (mg/L) }\end{array}$ & $\begin{array}{c}\text { Nitrate plus } \\
\text { nitrite, wa- } \\
\text { ter, filtered, } \\
\text { (mg/L as } \\
\text { nitrogen) }\end{array}$ & $\begin{array}{l}\text { Bromide, } \\
\text { water, } \\
\text { filtered, } \\
\text { (mg/L) }\end{array}$ & $\begin{array}{c}\text { Ammonia, } \\
\text { water, } \\
\text { filtered, } \\
\text { (mg/Las } \\
\text { nitrogen) }\end{array}$ & $\begin{array}{c}\text { Commercial, } \\
\text { (percent) }\end{array}$ & $\begin{array}{c}\text { Industrial, } \\
\text { (percent) }\end{array}$ & $\begin{array}{c}\text { Multi- } \\
\text { residential, } \\
\text { (percent) }\end{array}$ & $\begin{array}{c}\text { Residential } \\
\text { single } \\
\text { family, } \\
\text { (percent) }\end{array}$ & $\begin{array}{c}\text { Rural, } \\
\text { (percent) }\end{array}$ & $\begin{array}{c}\text { Unclassi- } \\
\text { fied, } \\
\text { (percent) }\end{array}$ & $\begin{array}{l}\text { Utilities, } \\
\text { (percent) }\end{array}$ & $\begin{array}{c}\text { Vacant } \\
\text { land, } \\
\text { (percent) }\end{array}$ & $\begin{array}{c}\text { Number } \\
\text { of } \\
\text { septic } \\
\text { tanks }\end{array}$ \\
\hline 385605119381801 & 5.9 & - & - & - & - & 0.00 & 0.00 & 0.00 & 30.75 & 0.00 & 6.45 & 0.00 & 62.80 & 21 \\
\hline 385610119415001 & 6.9 & - & - & M & - & 0.00 & 0.00 & 1.13 & 50.93 & 0.00 & 10.33 & 0.00 & 37.61 & 40 \\
\hline 385254119404201 & 8.77 & - & - & - & - & 0.00 & 0.00 & 4.44 & 64.61 & 0.00 & 5.90 & 0.00 & 25.06 & 95 \\
\hline 390542119472001 & 8.02 & - & - & 0.06 & $<.02$ & 6.20 & 0.00 & 1.70 & 59.24 & 0.00 & 11.30 & 7.17 & 14.40 & 103 \\
\hline 385654119431801 & 10.5 & - & - & 0.06 & $<.02$ & 0.00 & 0.00 & 0.00 & 51.81 & 33.86 & 2.18 & 0.00 & 12.15 & 25 \\
\hline 390457119491301 & 1.38 & - & - & $<.05$ & $<.02$ & 0.00 & 0.00 & 1.02 & 37.73 & 49.63 & 4.93 & 0.00 & 6.69 & 45 \\
\hline 385335119453501 & 4.82 & - & - & M & - & 1.25 & 0.00 & 3.31 & 74.47 & 8.25 & 8.15 & 0.14 & 4.44 & 70 \\
\hline 385106119462601 & 7.95 & - & - & - & - & 0.00 & 0.00 & 0.00 & 2.18 & 96.23 & 1.59 & 0.00 & 0.00 & 2 \\
\hline 390138119434201 & 11.8 & - & - & 0.1 & - & 0.52 & 0.00 & 1.55 & 47.46 & 38.54 & 8.56 & 0.00 & 3.38 & 101 \\
\hline 385339119490501 & - & - & - & - & - & 0.00 & 0.00 & 1.90 & 36.64 & 26.49 & 4.47 & 0.00 & 30.51 & 50 \\
\hline 390010119504101 & 2.23 & - & - & M & - & 3.07 & 0.00 & 7.34 & 46.55 & 14.51 & 11.53 & 0.00 & 17.01 & 107 \\
\hline 390015119500101 & 2.72 & - & - & $<.05$ & $<.02$ & 9.56 & 0.00 & 6.09 & 43.72 & 15.83 & 6.86 & 0.00 & 17.95 & 41 \\
\hline 385843119450501 & - & 36.00 & 1.90 & - & - & 0.00 & 0.00 & 0.00 & 0.00 & 100.00 & 0.00 & 0.00 & 0.00 & 0 \\
\hline 385927119451301 & - & 64.00 & 4.10 & - & - & 0.00 & 0.00 & 0.00 & 0.00 & 100.00 & 0.00 & 0.00 & 0.00 & 0 \\
\hline 385921119425101 & - & 4.10 & 0.20 & - & - & 0.00 & 0.00 & 0.80 & 0.00 & 84.32 & 0.00 & 0.00 & 14.88 & 1 \\
\hline 390041119424001 & - & 4.30 & 0.80 & - & - & 0.00 & 0.00 & 0.06 & 20.83 & 61.50 & 4.02 & 0.00 & 13.58 & 19 \\
\hline 390115119441601 & - & 11.00 & 7.50 & - & - & 0.00 & 0.00 & 0.00 & 7.05 & 88.55 & 0.47 & 0.00 & 3.93 & 7 \\
\hline 385604119435601 & 9.33 & - & - & M & - & 9.31 & 1.88 & 7.82 & 28.70 & 11.94 & 18.57 & 0.04 & 21.73 & 2 \\
\hline 385444119453301 & 5.04 & - & - & M & - & 0.00 & 0.00 & 5.11 & 30.48 & 40.45 & 8.70 & 0.00 & 15.26 & 41 \\
\hline 385751119470001 & 5.08 & - & - & M & - & 32.09 & 0.19 & 1.78 & 35.76 & 5.22 & 16.96 & 0.00 & 7.99 & 3 \\
\hline 385742119453801 & 5.35 & - & - & M & - & 2.37 & 0.00 & 0.50 & 26.44 & 25.04 & 12.88 & 0.00 & 32.77 & 1 \\
\hline 385652119471401 & 1.85 & - & - & M & - & 0.00 & 0.00 & 0.00 & 2.85 & 97.15 & 0.00 & 0.00 & 0.00 & 3 \\
\hline 385441119485201 & 1.11 & - & - & M & - & 0.00 & 0.00 & 5.46 & 40.96 & 35.42 & 3.31 & 0.00 & 14.86 & 18 \\
\hline 385604119392301 & 11.6 & - & - & M & - & 2.88 & 0.00 & 0.00 & 49.67 & 0.00 & 6.81 & 0.17 & 40.48 & 46 \\
\hline 385821119502201 & 4.25 & - & - & $\mathrm{M}$ & - & 0.00 & 0.00 & 2.19 & 18.69 & 66.17 & 4.45 & 0.00 & 8.51 & 7 \\
\hline 385612119470901 & 6.81 & - & - & M & - & 0.77 & 0.00 & 0.00 & 26.35 & 54.41 & 0.77 & 0.00 & 17.71 & 12 \\
\hline 390222119462401 & 4.26 & - & - & - & - & 0.00 & 0.00 & 31.93 & 31.31 & 11.43 & 4.30 & 0.00 & 21.03 & 13 \\
\hline 385639119413701 & 9.56 & - & - & M & - & 0.00 & 0.00 & 4.01 & 79.65 & 0.00 & 4.16 & 0.00 & 12.17 & 48 \\
\hline 385641119391101 & 12.7 & - & - & $\mathrm{M}$ & - & 0.00 & 0.00 & 6.51 & 70.95 & 0.00 & 3.85 & 0.00 & 18.70 & 30 \\
\hline 385307119412201 & 14.6 & - & - & 0.1 & - & 0.03 & 0.00 & 5.94 & 71.36 & 0.00 & 14.62 & 0.00 & 8.06 & 118 \\
\hline 385326119411401 & 17.9 & - & - & M & - & 0.00 & 0.00 & 1.84 & 82.64 & 0.00 & 8.26 & 0.00 & 7.26 & 145 \\
\hline 385714119384501 & 38.8 & - & - & M & - & 0.00 & 0.00 & 0.61 & 35.49 & 0.00 & 5.15 & 0.00 & 58.75 & 21 \\
\hline
\end{tabular}


Appendix 1. Field, nutrient, chloride, and bromide chemical data, and land use and number of septic tanks within 500 meters of each well.-Continued [Data from station number in bold comes from other sources and is not included in the USGS NWIS database system. USGS, U.S. Geological Survey; NWIS, National Water Information System; mm/dd/yyy, month/day/year; NAD83, North American Datum of 1983; mg/L, milligrams per liter; $\mu \mathrm{S} / \mathrm{cm}$, microsiemens per centimeter; —, no data; E, estimate; <, less than; M, presence of material verified but not quantified]

\begin{tabular}{|c|c|c|c|c|c|c|c|c|c|c|}
\hline Station number & Station name & $\begin{array}{c}\text { Date } \\
\text { (mm/dd//yyy) }\end{array}$ & Round & $\begin{array}{l}\text { Latitude-longitude } \\
\text { (NAD83) }\end{array}$ & $\begin{array}{l}\text { Well } \\
\text { depth, } \\
\text { (feet) }\end{array}$ & $\begin{array}{c}\text { pH, water, } \\
\text { unfiltered, } \\
\text { field, } \\
\text { (standard } \\
\text { units) }\end{array}$ & $\begin{array}{c}\text { Dissolved } \\
\text { oxygen, } \\
\text { water, } \\
\text { unfiltered, } \\
\text { (mg/L) }\end{array}$ & $\begin{array}{c}\text { Specific } \\
\text { conductance, } \\
\text { water, } \\
\text { unfiltered, } \\
(\mu \mathrm{S} / \mathrm{cm})\end{array}$ & $\begin{array}{c}\text { Tempera- } \\
\text { ture, water, } \\
\text { (degrees } \\
\text { Celsius) }\end{array}$ & $\begin{array}{l}\text { Nitrate, wa- } \\
\text { ter, filtered, } \\
\text { field, (mg/L as } \\
\text { nitrogen) }\end{array}$ \\
\hline 385707119420701 & 105 N13 E20 35ABCB1 & $1 / 8 / 2009$ & Round 1 & $385706 \mathrm{~N} 1194220 \mathrm{~W}$ & - & 7.5 & 1.4 & 156 & 14.5 & 0.3 \\
\hline 390043119423501 & 105 N13 E20 11BABB1 & $1 / 8 / 2009$ & Round 1 & $390043 \mathrm{~N} 1194223 \mathrm{~W}$ & - & 7.9 & 1.7 & 201 & 14.2 & 1.2 \\
\hline 385255119412501 & 105 N12 E20 24CDCC1 & $1 / 9 / 2009$ & Round 1 & $385254 \mathrm{~N} 1194112 \mathrm{~W}$ & 200 & 7.2 & 0.6 & 148 & 13.4 & 0.7 \\
\hline 385320119405001 & 105 N12 E20 24ADCB1 & $1 / 9 / 2009$ & Round 1 & $385322 \mathrm{~N} 1194005 \mathrm{~W}$ & 180 & 8.8 & 6.1 & 284 & 12 & 5.9 \\
\hline 390046119502801 & 105 N13 E19 03CCC 1 & $1 / 12 / 2009$ & Round 1 & $390046 \mathrm{~N} 1195002 \mathrm{~W}$ & 180 & 8.1 & 5.5 & 157 & 10.3 & 2.4 \\
\hline 390150119435401 & 105 N14 E20 34CBCD1 & $1 / 12 / 2009$ & Round 1 & $390149 \mathrm{~N} 1194335 \mathrm{~W}$ & 160 & 7.7 & 4.2 & 215 & 11.4 & 3.8 \\
\hline 390016119504101 & $\begin{array}{l}105 \text { N13 E19 09DAAB1 } \\
\text { Genoa State Park }\end{array}$ & $1 / 12 / 2009$ & Round 1 & $390015 \mathrm{~N} 1195004 \mathrm{~W}$ & 159 & 7.3 & 1.3 & 189 & 12.1 & 0.1 \\
\hline 385246119485201 & 105 N12 E19 26ABB 2 & $1 / 13 / 2009$ & Round 1 & $385246 \mathrm{~N} 1194885 \mathrm{~W}$ & 122 & 8.6 & 0.6 & 71 & 16.1 & $<.1$ \\
\hline 385620119502601 & 105 N12 E19 03BBAB1 & $1 / 15 / 2009$ & Round 1 & $385619 \mathrm{~N} 1195002 \mathrm{~W}$ & - & 6.8 & 4.7 & 101 & 11.1 & 5.1 \\
\hline 385816119482401 & $\begin{array}{l}\text { 105 N13 E19 23DDAD1 } \\
\text { USGS - Muller Lane }\end{array}$ & $1 / 15 / 2009$ & Round 1 & $385815 \mathrm{~N} 1194882 \mathrm{~W}$ & 21 & 7.7 & 2.6 & 325 & 10.9 & 0.5 \\
\hline 385446119482001 & 105 N12 E19 12CCBC1 & $1 / 15 / 2009$ & Round 1 & $385446 \mathrm{~N} 1194882 \mathrm{~W}$ & - & 7.3 & 1.8 & 55 & 9.4 & 1.5 \\
\hline 385554119461402 & 105 N12 E20 06DAAA1 & $1 / 15 / 2009$ & Round 1 & $385554 \mathrm{~N} 1194661 \mathrm{~W}$ & 100 & 6.7 & 2 & 121 & 10.5 & 2.1 \\
\hline 385333119410401 & 105 N12 E20 24ABCD1 & $1 / 29 / 2009$ & Round 1 & $385333 \mathrm{~N} 1194110 \mathrm{~W}$ & - & 7.4 & 7 & 306 & 11.9 & 5.9 \\
\hline 390148119433501 & 105 N14 E20 34CDBA1 & $1 / 29 / 2009$ & Round 1 & $390148 \mathrm{~N} 1194333 \mathrm{~W}$ & - & 7.5 & 4.3 & 236 & 12.3 & 5.5 \\
\hline 385332119411301 & 105 N12 E20 24BDAA1 & $1 / 29 / 2009$ & Round 1 & $385331 \mathrm{~N} 1194111 \mathrm{~W}$ & 151 & 7.5 & 6.6 & 238 & 12.5 & 5 \\
\hline 385329119412101 & 105 N12 E20 24BDBD1 & $1 / 29 / 2009$ & Round 1 & $385328 \mathrm{~N} 1194112 \mathrm{~W}$ & - & 7.4 & 7.1 & 284 & 12.3 & 7.1 \\
\hline 390150119432701 & 105 N14 E20 34CADD1 & $1 / 29 / 2009$ & Round 1 & 390149 N $1194332 \mathrm{~W}$ & - & 7.5 & 1.9 & 221 & 15.8 & 6 \\
\hline 385801119421501 & 105 N13 E20 26ABBB1 & $3 / 18 / 2009$ & Round 2 & $385807 \mathrm{~N} 1194221 \mathrm{~W}$ & 130 & 7.4 & 6 & 248 & 15.5 & - \\
\hline 385509119414801 & 105 N12 E20 11ADD 1 & $3 / 18 / 2009$ & Round 2 & $385509 \mathrm{~N} 1194114 \mathrm{~W}$ & 125 & 7.6 & 7.4 & 450 & 14.4 & - \\
\hline 390232119443201 & 105 N14 E20 28CDC 1 & $3 / 19 / 2009$ & Round 2 & $390232 \mathrm{~N} 1194443 \mathrm{~W}$ & 88 & 7.5 & 4 & 650 & 14.8 & - \\
\hline 385305119405801 & 105 N12 E20 24DCAA1 & $6 / 3 / 2009$ & Round 2 & $385304 \mathrm{~N} 1194005 \mathrm{~W}$ & 190 & 7.1 & 5.5 & 481 & 15.4 & 18 \\
\hline 385323119405801 & 105 N12 E20 24ACDD1 & $6 / 3 / 2009$ & Round 2 & $385323 \mathrm{~N} 1194005 \mathrm{~W}$ & 200 & 6.3 & 4.9 & 403 & 17 & 5.2 \\
\hline 385310119411901 & 105 N12 E20 24CADB1 & $6 / 3 / 2009$ & Round 2 & $385310 \mathrm{~N} 1194111 \mathrm{~W}$ & 150 & 7 & 4.6 & 446 & 21.2 & 8.6 \\
\hline 385311119410401 & 105 N12 E20 24DBCA1 & $6 / 3 / 2009$ & Round 2 & $385311 \mathrm{~N} 1194110 \mathrm{~W}$ & - & 7 & 6.1 & 440 & 13.6 & 7.3 \\
\hline 385318119403901 & 105 N12 E20 24DAAA1 & $6 / 4 / 2009$ & Round 2 & $385317 \mathrm{~N} 1194003 \mathrm{~W}$ & - & 7.7 & 6.5 & 320 & 17.5 & 3.5 \\
\hline 385339119412101 & 105 N12 E20 24BACA1 & $6 / 4 / 2009$ & Round 2 & $385338 \mathrm{~N} 1194112 \mathrm{~W}$ & 220 & 6.7 & 3.4 & 228 & 15.2 & 1.2 \\
\hline 385326119412601 & 105 N12 E20 24BCDA1 & $6 / 4 / 2009$ & Round 2 & $385326 \mathrm{~N} 1194112 \mathrm{~W}$ & 100 & 6.7 & 1.1 & 140 & 16.5 & 0.2 \\
\hline 385341119403301 & 105 N12 E21 19BBBD1 & $6 / 4 / 2009$ & Round 2 & $385340 \mathrm{~N} 1194003 \mathrm{~W}$ & 260 & 7.8 & 6.2 & 223 & 16.2 & 1.1 \\
\hline 385309119412801 & 105 N12 E20 24CACC 1 & $6 / 4 / 2009$ & Round 2 & $385309 \mathrm{~N} 1194112 \mathrm{~W}$ & - & 7.5 & 3.2 & 203 & 16.8 & 0.5 \\
\hline 385343119452301 & $\begin{array}{l}105 \text { N12 E20 20ABAB1 } \\
\text { Gardnerville Ranchos } 5\end{array}$ & $6 / 5 / 2009$ & Round 2 & $385343 \mathrm{~N} 1194552 \mathrm{~W}$ & 450 & 7.5 & 5.6 & 152 & 13.9 & 1.8 \\
\hline 385253119404001 & 105 N12 E20 25AAAB1 & $6 / 5 / 2009$ & Round 2 & $385253 \mathrm{~N} 1194004 \mathrm{~W}$ & 300 & 7.2 & 7.2 & 244 & 15.8 & 4.7 \\
\hline 385320119411701 & 105 N12 E20 24BDDC1 & $6 / 5 / 2009$ & Round 2 & $385319 \mathrm{~N} 1194111 \mathrm{~W}$ & 160 & 7.4 & 3.3 & 359 & 14.7 & 5.7 \\
\hline 385321119405001 & 105 N12 E20 24ADCD1 & $6 / 5 / 2009$ & Round 2 & $385320 \mathrm{~N} 1194004 \mathrm{~W}$ & - & 5.8 & 6.5 & 319 & 14 & 5.6 \\
\hline
\end{tabular}


Appendix 1. Field, nutrient, chloride, and bromide chemical data, and land use and number of septic tanks within 500 meters of each well.-Continued [Data from station number in bold comes from other sources and is not included in the USGS NWIS database system. USGS, U.S. Geological Survey; NWIS, National Water Information System; m/dd/yyy, month/day/year; NAD83, North American Datum of 1983; mg/L, milligrams per liter; —, no data; E, estimate; <, less than; M, presence of material verified but not quantified]

\begin{tabular}{|c|c|c|c|c|c|c|c|c|c|c|c|c|c|c|}
\hline Station number & $\begin{array}{c}\text { Chloride, } \\
\text { water, fil- } \\
\text { tered, field, } \\
(\mathrm{mg} / \mathrm{L})\end{array}$ & $\begin{array}{l}\text { Chloride, } \\
\text { water, } \\
\text { filtered, } \\
(\mathbf{m g} / \mathrm{L})\end{array}$ & $\begin{array}{c}\text { Nitrate plus } \\
\text { nitrite, wa- } \\
\text { ter, filtered, } \\
\text { (mg/L as } \\
\text { nitrogen) }\end{array}$ & $\begin{array}{l}\text { Bromide, } \\
\text { water, } \\
\text { filtered, } \\
(\mathbf{m g} / \mathrm{L})\end{array}$ & $\begin{array}{c}\text { Ammonia, } \\
\text { water, } \\
\text { filtered, } \\
\text { (mg/Las } \\
\text { nitrogen) }\end{array}$ & $\begin{array}{c}\text { Commercial, } \\
\text { (percent) }\end{array}$ & $\begin{array}{c}\text { Industrial, } \\
\text { (percent) }\end{array}$ & $\begin{array}{c}\text { Multi- } \\
\text { residential, } \\
\text { (percent) }\end{array}$ & $\begin{array}{l}\text { Residential } \\
\text { single } \\
\text { family, } \\
\text { (percent) }\end{array}$ & $\begin{array}{c}\text { Rural, } \\
\text { (percent) }\end{array}$ & $\begin{array}{c}\text { Unclassi- } \\
\text { fied, } \\
\text { (percent) }\end{array}$ & $\begin{array}{l}\text { Utilities, } \\
\text { (percent) }\end{array}$ & $\begin{array}{c}\text { Vacant } \\
\text { land, } \\
\text { (percent) }\end{array}$ & $\begin{array}{c}\text { Number } \\
\text { of } \\
\text { septic } \\
\text { tanks }\end{array}$ \\
\hline 385707119420701 & 7.09 & - & - & M & - & 0.00 & 0.00 & 12.36 & 76.44 & 0.00 & 6.02 & 0.00 & 5.17 & 41 \\
\hline 390043119423501 & 12 & - & - & M & - & 0.00 & 0.00 & 2.24 & 29.77 & 45.06 & 4.59 & 0.00 & 18.34 & 28 \\
\hline 385255119412501 & 8.27 & - & - & M & - & 22.01 & 0.00 & 8.90 & 40.12 & 0.00 & 16.76 & 0.00 & 12.20 & 63 \\
\hline 385320119405001 & 15.6 & - & - & $<.1$ & - & 0.00 & 0.00 & 3.25 & 85.62 & 0.00 & 0.00 & 0.00 & 11.13 & 116 \\
\hline 390046119502801 & 5.53 & - & - & M & - & 10.57 & 0.00 & 10.14 & 57.51 & 0.00 & 0.00 & 0.00 & 21.78 & 36 \\
\hline 390150119435401 & 10.6 & - & - & M & - & 0.52 & 0.00 & 2.78 & 76.33 & 3.73 & 12.19 & 0.00 & 4.45 & 162 \\
\hline 390016119504101 & 15.3 & - & - & M & - & 2.67 & 0.00 & 6.29 & 55.56 & 8.32 & 12.14 & 0.00 & 15.02 & 120 \\
\hline 385246119485201 & 0.84 & - & - & $<.1$ & - & 0.00 & 0.00 & 0.00 & 35.09 & 54.60 & 5.26 & 0.00 & 5.05 & 31 \\
\hline 385620119502601 & 3.55 & - & - & M & - & 0.00 & 0.00 & 2.44 & 61.19 & 25.87 & 5.92 & 0.00 & 4.58 & 74 \\
\hline 385816119482401 & 8.68 & 6.89 & 0.683 & Е .01 & $<.020$ & 0.00 & 0.00 & 0.00 & 0.00 & 96.78 & 3.22 & 0.00 & 0.00 & 1 \\
\hline 385446119482001 & 0.76 & 0.89 & 0.797 & $<.02$ & $<.020$ & 0.00 & 0.00 & 2.85 & 31.55 & 39.61 & 5.51 & 0.00 & 20.48 & 17 \\
\hline 385554119461402 & 4.82 & 5.01 & 2.46 & $<.02$ & $<.020$ & 0.00 & 0.00 & 0.00 & 0.00 & 98.00 & 2.00 & 0.00 & 0.00 & 5 \\
\hline 385333119410401 & 13.8 & - & - & M & - & 0.00 & 0.00 & 1.98 & 85.01 & 0.00 & 10.26 & 0.00 & 2.75 & 143 \\
\hline 390148119433501 & 13.9 & - & - & M & - & 0.00 & 0.00 & 2.07 & 76.49 & 7.27 & 11.40 & 0.00 & 2.77 & 158 \\
\hline 385332119411301 & 13.7 & - & - & M & - & 0.00 & 0.00 & 1.03 & 80.72 & 0.00 & 9.39 & 0.00 & 8.85 & 144 \\
\hline 385329119412101 & 21.3 & - & - & M & - & 0.00 & 0.00 & 0.87 & 75.90 & 1.40 & 8.10 & 0.00 & 13.74 & 139 \\
\hline 390150119432701 & 11.5 & - & - & M & - & 0.00 & 0.00 & 3.30 & 77.88 & 3.72 & 12.15 & 0.00 & 2.95 & 166 \\
\hline 385801119421501 & - & 5.81 & 1.04 & - & $<.020$ & 0.00 & 0.00 & 15.34 & 3.96 & 5.10 & 6.79 & 0.00 & 68.81 & 8 \\
\hline 385509119414801 & - & 22 & 7.14 & - & $<.020$ & 3.65 & 14.89 & 2.26 & 53.25 & 0.00 & 9.08 & 0.00 & 16.88 & 70 \\
\hline 390232119443201 & - & 35.1 & 9.46 & - & $<.020$ & 0.00 & 0.00 & 0.53 & 83.81 & 0.00 & 14.08 & 0.00 & 1.58 & 129 \\
\hline 385305119405801 & 27.4 & - & - & - & - & 0.00 & 0.00 & 3.91 & 81.15 & 0.00 & 8.91 & 0.00 & 6.04 & 129 \\
\hline 385323119405801 & 23.7 & - & - & - & - & 0.00 & 0.00 & 2.48 & 85.40 & 0.00 & 8.62 & 0.00 & 3.50 & 138 \\
\hline 385310119411901 & 50.7 & - & - & - & - & 0.00 & 0.00 & 2.50 & 74.94 & 0.00 & 13.16 & 0.00 & 9.40 & 134 \\
\hline 385311119410401 & 25.5 & - & - & - & - & 0.00 & 0.00 & 5.34 & 80.76 & 0.00 & 9.08 & 0.00 & 4.82 & 147 \\
\hline 385318119403901 & 11.9 & - & - & 0.1 & - & 0.00 & 0.00 & 4.08 & 72.54 & 0.00 & 7.11 & 0.00 & 16.27 & 90 \\
\hline 385339119412101 & 17.3 & - & - & - & - & 0.00 & 0.00 & 0.02 & 53.66 & 6.14 & 6.53 & 0.00 & 33.65 & 100 \\
\hline 385326119412601 & 4.95 & - & - & 0.2 & - & 0.00 & 0.00 & 0.87 & 60.81 & 5.50 & 8.85 & 0.00 & 23.97 & 113 \\
\hline 385341119403301 & 8.6 & - & - & 0.2 & - & 0.65 & 0.00 & 2.58 & 62.98 & 0.00 & 6.83 & 0.00 & 26.96 & 69 \\
\hline 385309119412801 & 6.19 & - & - & 0.1 & - & 2.70 & 0.00 & 4.65 & 67.13 & 0.00 & 15.56 & 0.00 & 9.96 & 114 \\
\hline 385343119452301 & 6.35 & - & - & 0.1 & - & 3.99 & 18.96 & 1.05 & 58.59 & 12.58 & 0.00 & 2.22 & 2.62 & 55 \\
\hline 385253119404001 & 10.5 & - & - & - & - & 0.00 & 0.00 & 3.58 & 61.46 & 0.00 & 5.44 & 0.00 & 29.52 & 87 \\
\hline 385320119411701 & 13.4 & - & - & 0.1 & - & 0.00 & 0.00 & 1.84 & 82.93 & 0.00 & 9.80 & 0.00 & 5.43 & 145 \\
\hline 385321119405001 & 14.9 & - & - & - & - & 0.00 & 0.00 & 3.55 & 75.27 & 0.00 & 8.69 & 0.00 & 12.50 & 115 \\
\hline
\end{tabular}


Appendix 1. Field, nutrient, chloride, and bromide chemical data, and land use and number of septic tanks within 500 meters of each well.-Continued [Data from station number in bold comes from other sources and is not included in the USGS NWIS database system. USGS, U.S. Geological Survey; NWIS, National Water Information System; mm/dd/yyy, month/day/year; NAD83, North American Datum of 1983; mg/L, milligrams per liter; $\mu \mathrm{S} / \mathrm{cm}$, microsiemens per centimeter; 一, no data; E, estimate; <, less than; M, presence of material verified but not quantified]

\begin{tabular}{|c|c|c|c|c|c|c|c|c|c|c|}
\hline Station number & Station name & $\begin{array}{c}\text { Date } \\
\text { (mm/dd/yyyy) }\end{array}$ & Round & $\begin{array}{l}\text { Latitude-longitude } \\
\text { (NAD83) }\end{array}$ & $\begin{array}{c}\text { Well } \\
\text { depth, } \\
\text { (feet) }\end{array}$ & $\begin{array}{c}\text { pH, water, } \\
\text { unfiltered, } \\
\text { field, } \\
\text { (standard } \\
\text { units) }\end{array}$ & $\begin{array}{c}\text { Dissolved } \\
\text { oxygen, } \\
\text { water, } \\
\text { unfiltered, } \\
\text { (mg/L) }\end{array}$ & $\begin{array}{c}\text { Specific } \\
\text { conductance, } \\
\text { water, } \\
\text { unfiltered, } \\
(\mu \mathrm{S} / \mathrm{cm})\end{array}$ & $\begin{array}{c}\text { Tempera- } \\
\text { ture, water, } \\
\text { (degrees } \\
\text { Celsius) }\end{array}$ & $\begin{array}{c}\text { Nitrate, wa- } \\
\text { ter, filtered, } \\
\text { field, (mg/L as } \\
\text { nitrogen) }\end{array}$ \\
\hline 385319119454701 & 105 N12 E20 20CABB1 & $6 / 8 / 2009$ & Round 2 & $385319 \mathrm{~N} 1194554 \mathrm{~W}$ & 140 & 7.2 & 4.8 & 181 & 21.2 & 2.5 \\
\hline 385431119432101 & 105 N12 E20 15ABB 1 & $6 / 8 / 2009$ & Round 2 & $385431 \mathrm{~N} 1194332 \mathrm{~W}$ & - & 7.7 & 4.1 & 125 & 15.5 & 0.2 \\
\hline 385347119452901 & 105 N17 E20 17DCDC1 & $6 / 8 / 2009$ & Round 2 & $385346 \mathrm{~N} 1194552 \mathrm{~W}$ & 146 & 6.6 & 6 & 130 & 21.1 & 0.6 \\
\hline 385404119453201 & 105 N12 E20 17DBCA1 & $6 / 8 / 2009$ & Round 2 & $385404 \mathrm{~N} 1194553 \mathrm{~W}$ & 133 & 8 & 7.4 & 186 & 15 & 0.5 \\
\hline 385408119454401 & 105 N12 E20 17CABD1 & $6 / 8 / 2009$ & Round 2 & $385408 \mathrm{~N} 1194554 \mathrm{~W}$ & - & 7.4 & 6.8 & 187 & 15 & 3.2 \\
\hline 385438119522801 & 105 N12 E19 08CDC 1 & $6 / 8 / 2009$ & Round 2 & $385438 \mathrm{~N} 1194554 \mathrm{~W}$ & - & 6.2 & 4.5 & 151 & 15.6 & 1.9 \\
\hline 390034119502801 & 105 N13 E19 10BBDB1 & 6/9/2009 & Round 2 & $390033 \mathrm{~N} 1195002 \mathrm{~W}$ & 94 & 6.6 & 5.4 & 124 & 13.2 & 0.7 \\
\hline 385625119503001 & 105 N13 E19 34CCCD1 & $6 / 9 / 2009$ & Round 2 & $385625 \mathrm{~N} 1195003 \mathrm{~W}$ & - & 7.1 & 4.5 & 104 & 17.9 & 2.1 \\
\hline 385603119503201 & 105 N12 E19 03BCB 1 & $6 / 9 / 2009$ & Round 2 & $385603 \mathrm{~N} 1195003 \mathrm{~W}$ & 15 & 7.6 & 4 & 75 & 14.5 & 2.5 \\
\hline 385600119502401 & 105 N12 E19 03BCDA1 & $6 / 9 / 2009$ & Round 2 & $385600 \mathrm{~N} 1195002 \mathrm{~W}$ & 140 & 5.8 & 7.5 & 80 & 12.9 & 2 \\
\hline 385548119501701 & 105 N12 E19 03CACC1 & $6 / 9 / 2009$ & Round 2 & $385548 \mathrm{~N} 1195001 \mathrm{~W}$ & 150 & 6.6 & 4.9 & 101 & 18.1 & 3.5 \\
\hline 390009119501701 & 105 N13 E19 10CACB1 & 6/10/2009 & Round 2 & $390009 \mathrm{~N} 1195001 \mathrm{~W}$ & - & 7 & 3.2 & 281 & 13.1 & 1.9 \\
\hline 385957119492101 & 105 N13 E19 11CCDB1 & 6/10/2009 & Round 2 & 385957 N $1194992 \mathrm{~W}$ & 135 & 6.1 & 4.8 & 278 & 17.9 & 0.2 \\
\hline 390012119502001 & 105 N13 E19 10CBA 1 & 6/10/2009 & Round 2 & $390012 \mathrm{~N} 1195002 \mathrm{~W}$ & 103 & 6.9 & 4 & 80 & 18.1 & 1.2 \\
\hline 390052119502701 & 105 N13 E19 03CCB 1 & $6 / 10 / 2009$ & Round 2 & $390052 \mathrm{~N} 1195002 \mathrm{~W}$ & - & 7.8 & 2.4 & 167 & 18.1 & 1.3 \\
\hline 390012119501201 & 105 N13 E19 10CAB 1 & 6/10/2009 & Round 2 & $390012 \mathrm{~N} 1195001 \mathrm{~W}$ & 97 & 6.3 & 4.2 & 152 & 20.1 & 0.6 \\
\hline 390119119500201 & 105 N13 E19 03BDAB1 & $6 / 10 / 2009$ & Round 2 & $390119 \mathrm{~N} 1195001 \mathrm{~W}$ & 128 & 8.1 & 6.5 & 184 & 23.2 & 0.1 \\
\hline 385958119491501 & 105 N13 E19 11CCA 1 & 6/10/2009 & Round 2 & $385958 \mathrm{~N} 1194991 \mathrm{~W}$ & 110 & 7.6 & 5.6 & 100 & 13.9 & 0.9 \\
\hline 385614119411001 & 105 N12 E20 01ABCB1 & $6 / 12 / 2009$ & Round 2 & $385613 \mathrm{~N} 1194110 \mathrm{~W}$ & - & 7.6 & 4.2 & 187 & 17.3 & 0.5 \\
\hline 385622119405601 & 105 N12 E20 01ABAA1 & $6 / 12 / 2009$ & Round 2 & $385622 \mathrm{~N} 1194005 \mathrm{~W}$ & 560 & 7.4 & 5.7 & 190 & 15.2 & 0.5 \\
\hline 385620119415601 & 105 N12 E20 02AABA1 & $6 / 12 / 2009$ & Round 2 & $385620 \mathrm{~N} 1194115 \mathrm{~W}$ & 240 & 8 & 6.3 & 159 & 17.2 & 0.5 \\
\hline 385616119415501 & 105 N12 E20 02AABC1 & $6 / 12 / 2009$ & Round 2 & $385616 \mathrm{~N} 1194115 \mathrm{~W}$ & 240 & 7.5 & 5.9 & 163 & 16.2 & 0.8 \\
\hline 390149119424201 & 105 N14 E20 35CCAB1 & $6 / 15 / 2009$ & Round 2 & $390148 \mathrm{~N} 1194224 \mathrm{~W}$ & - & 7.6 & 4.6 & 220 & 21.7 & 0.9 \\
\hline 390228119424701 & 105 N14 E20 35BBBA1 & $6 / 15 / 2009$ & Round 2 & 390227 N $1194224 \mathrm{~W}$ & 300 & 8.3 & 5.2 & 269 & 17.9 & 0.1 \\
\hline 390149119424202 & 105 N14 E20 35CCAB2 & $6 / 15 / 2009$ & Round 2 & 390148 N $1194224 \mathrm{~W}$ & - & 7.6 & 4.5 & 231 & 21.9 & 1.7 \\
\hline 390153119431001 & 105 N14 E20 34DBDA1 & $6 / 15 / 2009$ & Round 2 & $390153 \mathrm{~N} 1194331 \mathrm{~W}$ & - & 6.6 & 3.6 & 244 & 21.8 & 1.6 \\
\hline 390146119435201 & 105 N14 E20 34CCBA1 & $6 / 16 / 2009$ & Round 2 & $390145 \mathrm{~N} 1194335 \mathrm{~W}$ & - & 7.5 & 5.6 & 225 & 16.7 & 2.1 \\
\hline 390150119432501 & 105 N14 E20 24ADDC1 & $6 / 16 / 2009$ & Round 2 & $390149 \mathrm{~N} 1194332 \mathrm{~W}$ & - & 7.3 & 3.1 & 301 & 17.3 & 7.2 \\
\hline 390233119423801 & 105 N14 E20 26CCDA1 & $6 / 16 / 2009$ & Round 2 & $390233 \mathrm{~N} 1194223 \mathrm{~W}$ & 300 & 9.1 & 0.1 & 323 & 19.9 & 0.1 \\
\hline 390154119430301 & 105 N14 E20 34DACA1 & $6 / 16 / 2009$ & Round 2 & $390153 \mathrm{~N} 1194330 \mathrm{~W}$ & 139 & 6.9 & 3.7 & 248 & 17.9 & 4.2 \\
\hline 390252119430001 & 105 N14 E20 27DAAB1 & $6 / 16 / 2009$ & Round 2 & $390252 \mathrm{~N} 1194330 \mathrm{~W}$ & 340 & 8.2 & 0.8 & 266 & 18.7 & 0.1 \\
\hline 390202119424701 & 105 N14 E20 35CBBB1 & 6/16/2009 & Round 2 & $390202 \mathrm{~N} 1194334 \mathrm{~W}$ & 280 & 7.3 & 2.4 & 209 & 17 & 0.6 \\
\hline 390152119425401 & 105 N14 E20 34DADD1 & $6 / 19 / 2009$ & Round 2 & $390152 \mathrm{~N} 1194225 \mathrm{~W}$ & 110 & 7 & 2.5 & 115 & 19.1 & 1.1 \\
\hline 390232119441401 & 105 N14 E20 28DCD 1 & 6/19/2009 & Round 2 & $390232 \mathrm{~N} 1194441 \mathrm{~W}$ & - & 8 & 4.5 & 194 & 16.2 & 0.8 \\
\hline 390239119443901 & 105 N14 E20 28CDB 1 & 6/19/2009 & Round 2 & 390239 N $1194443 \mathrm{~W}$ & 140 & 8.1 & 5.2 & 236 & 19.9 & 0.7 \\
\hline
\end{tabular}


Appendix 1. Field, nutrient, chloride, and bromide chemical data, and land use and number of septic tanks within 500 meters of each well.-Continued [Data from station number in bold comes from other sources and is not included in the USGS NWIS database system. USGS, U.S. Geological Survey; NWIS, National Water Information System; m/dd/yyy, month/day/year; NAD83, North American Datum of 1983; mg/L, milligrams per liter; —, no data; E, estimate; <, less than; M, presence of material verified but not quantified]

\begin{tabular}{|c|c|c|c|c|c|c|c|c|c|c|c|c|c|c|}
\hline Station number & $\begin{array}{l}\text { Chloride, } \\
\text { water, fil- } \\
\text { tered, field, } \\
(\mathrm{mg} / \mathrm{L})\end{array}$ & $\begin{array}{c}\text { Chloride, } \\
\text { water, } \\
\text { filtered, } \\
\text { (mg/L) }\end{array}$ & $\begin{array}{l}\text { Nitrate plus } \\
\text { nitrite, wa- } \\
\text { ter, filtered, } \\
\text { (mg/L as } \\
\text { nitrogen) }\end{array}$ & $\begin{array}{l}\text { Bromide, } \\
\text { water, } \\
\text { filtered, } \\
(\mathbf{m g} / \mathbf{L})\end{array}$ & $\begin{array}{c}\text { Ammonia, } \\
\text { water, } \\
\text { filtered, } \\
\text { (mg// as } \\
\text { nitrogen) }\end{array}$ & $\begin{array}{c}\text { Commercial, } \\
\text { (percent) }\end{array}$ & $\begin{array}{l}\text { Industrial, } \\
\text { (percent) }\end{array}$ & $\begin{array}{c}\text { Multi- } \\
\text { residential, } \\
\text { (percent) }\end{array}$ & $\begin{array}{c}\text { Residential } \\
\text { single } \\
\text { family, } \\
\text { (percent) }\end{array}$ & $\begin{array}{c}\text { Rural, } \\
\text { (percent) }\end{array}$ & $\begin{array}{c}\text { Unclassi- } \\
\text { fied, } \\
\text { (percent) }\end{array}$ & $\begin{array}{l}\text { Utilities, } \\
\text { (percent) }\end{array}$ & $\begin{array}{c}\text { Vacant } \\
\text { land, } \\
\text { (percent) }\end{array}$ & $\begin{array}{c}\begin{array}{c}\text { Number } \\
\text { of } \\
\text { septic } \\
\text { tanks }\end{array} \\
\end{array}$ \\
\hline 385319119454701 & 2.45 & - & - & M & - & 0.00 & 0.00 & 1.95 & 60.84 & 30.68 & 3.87 & 0.00 & 2.65 & 34 \\
\hline 385431119432101 & 8.88 & - & - & 0.1 & - & 3.97 & 0.00 & 3.91 & 78.18 & 0.00 & 12.03 & 0.00 & 1.91 & 33 \\
\hline 385347119452901 & 3.83 & - & - & 0.1 & - & 2.52 & 18.23 & 0.97 & 59.83 & 3.68 & 7.86 & 2.06 & 4.84 & 61 \\
\hline 385404119453201 & 5.82 & - & - & 0.2 & - & 0.00 & 4.49 & 1.24 & 67.28 & 6.09 & 7.22 & 0.00 & 13.68 & 59 \\
\hline 385408119454401 & 7.17 & - & - & - & - & 0.00 & 0.00 & 9.01 & 63.59 & 17.62 & 6.51 & 0.00 & 3.26 & 66 \\
\hline 385438119522801 & 5.31 & - & - & 0.1 & - & 0.00 & 0.00 & 21.90 & 24.19 & 33.85 & 8.02 & 0.00 & 12.04 & 36 \\
\hline 390034119502801 & 6.71 & - & - & M & - & 9.78 & 0.00 & 8.50 & 51.42 & 0.00 & 9.80 & 0.00 & 20.50 & 65 \\
\hline 385625119503001 & 9.24 & - & - & $<.1$ & - & 0.00 & 0.00 & 0.00 & 64.45 & 29.68 & 0.00 & 0.00 & 5.86 & 63 \\
\hline 385603119503201 & 7.24 & - & - & 0.1 & - & 0.00 & 0.00 & 6.98 & 67.15 & 1.24 & 13.19 & 0.00 & 11.45 & 101 \\
\hline 385600119502401 & 3.27 & - & - & 0.1 & - & 0.00 & 0.00 & 18.98 & 50.98 & 9.38 & 9.62 & 0.00 & 11.04 & 93 \\
\hline 385548119501701 & 4.67 & - & - & 0.1 & - & 0.00 & 0.00 & 21.24 & 53.24 & 3.15 & 12.22 & 0.00 & 10.14 & 99 \\
\hline 390009119501701 & 5.6 & - & - & M & - & 0.44 & 0.00 & 3.55 & 38.28 & 42.43 & 7.12 & 0.00 & 8.18 & 54 \\
\hline 385957119492101 & 8.54 & - & - & M & - & 0.36 & 0.00 & 25.69 & 14.91 & 48.10 & 4.44 & 0.00 & 6.49 & 17 \\
\hline 390012119502001 & 4.12 & - & - & M & - & 0.92 & 0.00 & 4.60 & 45.66 & 29.65 & 7.83 & 0.00 & 11.35 & 68 \\
\hline 390052119502701 & 8.8 & - & - & 0.1 & - & 9.86 & 0.00 & 4.18 & 49.94 & 0.00 & 10.27 & 0.00 & 25.76 & 29 \\
\hline 390012119501201 & 2.37 & - & - & M & - & 0.00 & 0.00 & 4.36 & 45.65 & 34.80 & 7.77 & 0.00 & 7.43 & 51 \\
\hline 390119119500201 & 1.49 & - & - & M & - & 10.16 & 0.00 & 12.12 & 21.44 & 15.75 & 7.17 & 0.00 & 33.36 & 14 \\
\hline 385958119491501 & 3 & - & - & M & - & 0.36 & 0.00 & 23.44 & 14.91 & 49.83 & 4.42 & 0.00 & 7.03 & 17 \\
\hline 385614119411001 & 9.17 & - & - & M & - & 0.00 & 0.00 & 4.43 & 60.83 & 0.00 & 8.70 & 0.00 & 26.05 & 55 \\
\hline 385622119405601 & 10.2 & - & - & M & - & 0.00 & 0.00 & 1.60 & 66.66 & 0.00 & 7.47 & 0.00 & 24.26 & 44 \\
\hline 385620119415601 & 4.2 & - & - & - & - & 0.00 & 0.00 & 4.07 & 63.58 & 0.00 & 10.30 & 0.00 & 22.05 & 51 \\
\hline 385616119415501 & 10.6 & - & - & M & - & 0.00 & 0.00 & 1.39 & 50.83 & 0.00 & 10.47 & 0.00 & 37.31 & 45 \\
\hline 390149119424201 & 22.99 & - & - & - & - & 0.00 & 0.00 & 7.60 & 86.31 & 0.00 & 0.00 & 0.00 & 6.09 & 50 \\
\hline 390228119424701 & 19.8 & - & - & - & - & 0.00 & 0.00 & 5.11 & 75.33 & 0.00 & 10.42 & 0.00 & 9.13 & 125 \\
\hline 390149119424202 & 12.5 & - & - & 0.1 & - & 0.00 & 0.00 & 7.60 & 86.33 & 0.00 & 0.00 & 0.00 & 6.08 & 50 \\
\hline 390153119431001 & 13.2 & - & - & 0.2 & - & 0.00 & 0.00 & 2.71 & 77.88 & 0.00 & 13.02 & 0.00 & 6.40 & 152 \\
\hline 390146119435201 & 12.9 & - & - & 0.1 & - & 0.52 & 0.00 & 1.55 & 68.01 & 13.88 & 11.10 & 0.00 & 4.94 & 144 \\
\hline 390150119432501 & 19.3 & - & - & - & - & 0.00 & 0.00 & 3.35 & 78.03 & 3.11 & 12.26 & 0.00 & 3.24 & 163 \\
\hline 390233119423801 & 20.3 & - & - & - & - & 0.00 & 0.00 & 3.11 & 82.99 & 0.00 & 7.87 & 0.00 & 6.03 & 115 \\
\hline 390154119430301 & 12.2 & - & - & 0.1 & - & 0.00 & 0.00 & 3.65 & 79.00 & 0.00 & 12.70 & 0.00 & 4.65 & 123 \\
\hline 390252119430001 & 19.9 & - & - & - & - & 0.00 & 0.00 & 1.69 & 43.88 & 0.00 & 5.81 & 0.00 & 48.62 & 77 \\
\hline 390202119424701 & 7.14 & - & - & 0.1 & - & 0.00 & 0.00 & 3.44 & 83.56 & 0.00 & 11.64 & 0.00 & 1.36 & 173 \\
\hline 390152119425401 & 8.21 & - & - & 0.1 & - & 0.00 & 0.00 & 4.52 & 77.58 & 0.00 & 13.79 & 0.00 & 4.10 & 95 \\
\hline 390232119441401 & 7.04 & - & - & 0.2 & - & 0.00 & 0.00 & 0.53 & 85.56 & 0.00 & 11.23 & 0.00 & 2.69 & 157 \\
\hline 390239119443901 & 8.42 & - & - & 0.2 & - & 0.00 & 0.00 & 0.00 & 98.20 & 0.00 & 0.00 & 0.00 & 1.80 & 96 \\
\hline
\end{tabular}


Appendix 1. Field, nutrient, chloride, and bromide chemical data, and land use and number of septic tanks within 500 meters of each well.-Continued [Data from station number in bold comes from other sources and is not included in the USGS NWIS database system. USGS, U.S. Geological Survey; NWIS, National Water Information System; mm/dd/yyy, month/day/year; NAD83, North American Datum of 1983; mg/L, milligrams per liter; $\mu \mathrm{S} / \mathrm{cm}$, microsiemens per centimeter; —, no data; E, estimate; <, less than; $M$, presence of material verified but not quantified]

\begin{tabular}{|c|c|c|c|c|c|c|c|c|c|c|}
\hline Station number & Station name & $\begin{array}{c}\text { Date } \\
\text { (mm/dd//yyy) }\end{array}$ & Round & $\begin{array}{l}\text { Latitude-longitude } \\
\text { (NAD83) }\end{array}$ & $\begin{array}{c}\text { Well } \\
\text { depth, } \\
\text { (feet) }\end{array}$ & $\begin{array}{c}\text { pH, water, } \\
\text { unfiltered, } \\
\text { field, } \\
\text { (standard } \\
\text { units) }\end{array}$ & $\begin{array}{c}\text { Dissolved } \\
\text { oxygen, } \\
\text { water, } \\
\text { unfiltered, } \\
\text { (mg/L) }\end{array}$ & $\begin{array}{c}\text { Specific } \\
\text { conductance, } \\
\text { water, } \\
\text { unfiltered, } \\
(\mu \mathrm{S} / \mathrm{cm})\end{array}$ & $\begin{array}{c}\text { Tempera- } \\
\text { ture, water, } \\
\text { (degrees } \\
\text { Celsius) }\end{array}$ & $\begin{array}{c}\text { Nitrate, wa- } \\
\text { ter, filtered, } \\
\text { field, (mg/L as } \\
\text { nitrogen) }\end{array}$ \\
\hline 390159119425001 & 105 N14 E20 34DAA 1 & $6 / 19 / 2009$ & Round 2 & $390159 \mathrm{~N} 1194225 \mathrm{~W}$ & 147 & 7.1 & 2.1 & 121 & 17 & 0.7 \\
\hline 385548119385001 & 105 N12 E21 05DBDD1 & $6 / 22 / 2009$ & Round 2 & $385551 \mathrm{~N} 1193884 \mathrm{~W}$ & 70 & 6.5 & 3.5 & 287 & 17.7 & 0.2 \\
\hline 390109119421201 & 105 N13 E20 021 & $6 / 22 / 2009$ & Round 2 & $390109 \mathrm{~N} 1194221 \mathrm{~W}$ & 172 & 8.2 & 5.5 & 136 & 21.6 & 2.7 \\
\hline 390039119422601 & 105 N13 E20 11BAB 1 & $6 / 22 / 2009$ & Round 2 & $390039 \mathrm{~N} 1194222 \mathrm{~W}$ & - & 7 & 5.4 & 122 & 16.2 & 1.1 \\
\hline 385320119411701 & 105 N12 E20 24BDDC1 & $7 / 6 / 2009$ & Round 2 & $385319 \mathrm{~N} 1194111 \mathrm{~W}$ & 160 & - & - & - & - & - \\
\hline 385311119410401 & 105 N12 E20 24DBCA1 & $7 / 6 / 2009$ & Round 2 & $385311 \mathrm{~N} 1194110 \mathrm{~W}$ & - & 7 & - & 441 & - & - \\
\hline 385321119405001 & 105 N12 E20 24ADCD1 & $7 / 6 / 2009$ & Round 2 & $385320 \mathrm{~N} 1194004 \mathrm{~W}$ & - & 5.9 & - & 319 & - & - \\
\hline 390208119433201 & 105 N14 E20 34BDBD1 & $8 / 3 / 2009$ & Round 2 & $390207 \mathrm{~N} 1194333 \mathrm{~W}$ & 100 & 7.3 & 3.8 & 484 & 16.2 & - \\
\hline 390055119421901 & 105 N13 E20 02CDAB1 & $8 / 3 / 2009$ & Round 2 & $390054 \mathrm{~N} 1194222 \mathrm{~W}$ & 350 & 8.3 & 0.2 & 344 & 24.5 & - \\
\hline 390106119424301 & 105 N13 E20 02CBB 1 & $8 / 3 / 2009$ & Round 2 & $390107 \mathrm{~N} 1194224 \mathrm{~W}$ & 176 & 7.7 & 2.6 & 331 & 21.6 & - \\
\hline 385509119414801 & 105 N12 E20 11ADD 1 & $8 / 4 / 2009$ & Round 2 & $385509 \mathrm{~N} 1194114 \mathrm{~W}$ & 125 & 7.6 & 7.3 & 487 & 14.7 & - \\
\hline 385340119403601 & 105 N12 E20 24AAAA 1 & $8 / 5 / 2009$ & Round 2 & $385340 \mathrm{~N} 1194003 \mathrm{~W}$ & 195 & 7.9 & 5.3 & 335 & 15.8 & - \\
\hline 385321119405002 & 105 N12 E20 24ADCC2 & $8 / 5 / 2009$ & Round 2 & $385319 \mathrm{~N} 1194005 \mathrm{~W}$ & 145 & 7.8 & 6.4 & 492 & 14.4 & - \\
\hline 390542119472001 & 105 N14 E19 12ADAB1 & $8 / 5 / 2009$ & Round 2 & $390541 \mathrm{~N} 1194772 \mathrm{~W}$ & 155 & 7.8 & 3.5 & 244 & 15 & - \\
\hline 390021119504301 & 105 N13 E19 09ADCA1 & $8 / 6 / 2009$ & Round 2 & $390022 \mathrm{~N} 1195005 \mathrm{~W}$ & 180 & 7 & 6.7 & 292 & 13.7 & - \\
\hline 390457119491301 & 105 N14 E19 14BBD 1 & $8 / 6 / 2009$ & Round 2 & $390456 \mathrm{~N} 1194992 \mathrm{~W}$ & 100 & 8.5 & 6.1 & 119 & 14.9 & - \\
\hline 390015119500101 & 105 N13 E19 10DBB 1 & $8 / 6 / 2009$ & Round 2 & $390020 \mathrm{~N} 1195000 \mathrm{~W}$ & 115 & 7.3 & 2.7 & 221 & 13.4 & - \\
\hline 385351119452301 & 105 N12 E20 17DCDB1 & $8 / 12 / 2009$ & Round 2 & $385351 \mathrm{~N} 1194552 \mathrm{~W}$ & 115 & 6.5 & 6.6 & 340 & 15 & - \\
\hline 390446119451401 & $\begin{array}{l}105 \text { N14 E20 17ADCA1 } \\
\text { Wetlands } 5\end{array}$ & $8 / 13 / 2009$ & Round 2 & $390445 \mathrm{~N} 1194551 \mathrm{~W}$ & 27 & 6.9 & 1.1 & 3,310 & 12.9 & - \\
\hline 390222119462401 & 105 N14 E20 31AAC 1 & $8 / 13 / 2009$ & Round 2 & $390222 \mathrm{~N} 1194662 \mathrm{~W}$ & - & 8.1 & 0.2 & 268 & 15 & - \\
\hline 390140119460501 & 105 N14 E20 32CCDB1 & $8 / 13 / 2009$ & Round 2 & $390140 \mathrm{~N} 1194660 \mathrm{~W}$ & 140 & 8 & 0.2 & 394 & 14.6 & - \\
\hline 385337119454701 & 105 N12 E20 20BACC1 & $8 / 14 / 2009$ & Round 2 & $385337 \mathrm{~N} 1194554 \mathrm{~W}$ & 140 & 7.6 & 5.3 & 240 & 14.5 & - \\
\hline 385335119452301 & 105 N12 E20 20ABDC1 & $8 / 14 / 2009$ & Round 2 & $385335 \mathrm{~N} 1194552 \mathrm{~W}$ & 140 & 7.6 & 5.7 & 261 & 17.2 & - \\
\hline 385335119453501 & 105 N12 E20 20BDDD1 & $8 / 14 / 2009$ & Round 2 & $385335 \mathrm{~N} 1194553 \mathrm{~W}$ & 142 & 7.6 & 6.1 & 217 & 15.1 & - \\
\hline 385343119460601 & 105 N12 E20 20BBBC1 & $8 / 14 / 2009$ & Round 2 & $385343 \mathrm{~N} 1194660 \mathrm{~W}$ & 140 & 6.8 & 5.7 & 222 & 18.1 & - \\
\hline 385407119455901 & 105 N12 E20 17CBDB1 & $8 / 17 / 2009$ & Round 2 & $385407 \mathrm{~N} 1194555 \mathrm{~W}$ & 130 & 7.4 & 5.8 & 287 & 15.4 & - \\
\hline 385342119453101 & 105 N12 E20 20ABBC1 & $8 / 17 / 2009$ & Round 2 & $385342 \mathrm{~N} 1194553 \mathrm{~W}$ & 160 & 6.9 & 6.9 & 308 & 15.7 & - \\
\hline 385255119482301 & 105 N12 E19 23DDD 1 & $8 / 17 / 2009$ & Round 2 & $385254 \mathrm{~N} 1194883 \mathrm{~W}$ & 141 & 8.7 & 3.7 & 105 & 16.4 & - \\
\hline 385328119455801 & 105 N12 E20 20DBAB1 & $8 / 17 / 2009$ & Round 2 & $385328 \mathrm{~N} 1194555 \mathrm{~W}$ & 162 & 7.2 & 3.8 & 303 & 13.9 & - \\
\hline
\end{tabular}


Appendix 1. Field, nutrient, chloride, and bromide chemical data, and land use and number of septic tanks within 500 meters of each well.-Continued [Data from station number in bold comes from other sources and is not included in the USGS NWIS database system. USGS, U.S. Geological Survey; NWIS, National Water Information System; m/dd/yyy, month/day/year; NAD83, North American Datum of 1983; mg/L, milligrams per liter; —, no data; E, estimate; <, less than; M, presence of material verified but not quantified]

\begin{tabular}{|c|c|c|c|c|c|c|c|c|c|c|c|c|c|c|}
\hline Station number & $\begin{array}{l}\text { Chloride, } \\
\text { water, fil- } \\
\text { tered, field, } \\
\text { (mg/L) }\end{array}$ & $\begin{array}{l}\text { Chloride, } \\
\text { water, } \\
\text { filtered, } \\
\text { (mg/L) }\end{array}$ & $\begin{array}{l}\text { Nitrate plus } \\
\text { nitrite, wa- } \\
\text { ter, filtered, } \\
\text { (mg/L as } \\
\text { nitrogen) }\end{array}$ & $\begin{array}{l}\text { Bromide, } \\
\text { water, } \\
\text { filtered, } \\
\text { (mg/L) }\end{array}$ & $\begin{array}{c}\text { Ammonia, } \\
\text { water, } \\
\text { filtered, } \\
\text { (mg/L as } \\
\text { nitrogen) }\end{array}$ & $\begin{array}{c}\text { Commercial, } \\
\text { (percent) }\end{array}$ & $\begin{array}{c}\text { Industrial, } \\
\text { (percent) }\end{array}$ & $\begin{array}{c}\text { Multi- } \\
\text { residential, } \\
\text { (percent) }\end{array}$ & $\begin{array}{c}\text { Residential } \\
\text { single } \\
\text { family, } \\
\text { (percent) }\end{array}$ & $\begin{array}{c}\text { Rural, } \\
\text { (percent) }\end{array}$ & $\begin{array}{c}\text { Unclassi- } \\
\text { fied, } \\
\text { (percent) }\end{array}$ & $\begin{array}{l}\text { Utilities, } \\
\text { (percent) }\end{array}$ & $\begin{array}{c}\text { Vacant } \\
\text { land, } \\
\text { (percent) }\end{array}$ & $\begin{array}{c}\text { Number } \\
\text { of } \\
\text { septic } \\
\text { tanks }\end{array}$ \\
\hline 390159119425001 & 3.33 & - & - & 0.1 & - & 0.00 & 0.00 & 4.67 & 71.95 & 0.00 & 12.61 & 0.00 & 10.77 & 82 \\
\hline 385548119385001 & 6.36 & - & - & M & - & 0.00 & 0.00 & 0.00 & 44.33 & 0.00 & 0.00 & 0.00 & 55.67 & 46 \\
\hline 390109119421201 & 16.2 & - & - & - & - & 0.00 & 0.00 & 2.35 & 71.28 & 0.00 & 5.06 & 0.00 & 21.31 & 70 \\
\hline 390039119422601 & 16.9 & - & - & - & - & 0.00 & 0.00 & 3.58 & 34.94 & 30.27 & 5.58 & 0.00 & 25.64 & 28 \\
\hline 385320119411701 & - & 15.7 & 4.82 & 0.12 & - & 0.00 & 0.00 & 1.84 & 82.93 & 0.00 & 9.80 & 0.00 & 5.43 & 145 \\
\hline 385311119410401 & - & 38.7 & 7.71 & 0.25 & - & 0.00 & 0.00 & 5.34 & 80.76 & 0.00 & 9.08 & 0.00 & 4.82 & 147 \\
\hline 385321119405001 & - & 22.1 & 4.94 & 0.14 & - & 0.00 & 0.00 & 3.55 & 75.27 & 0.00 & 8.69 & 0.00 & 12.50 & 115 \\
\hline 390208119433201 & - & 24.2 & 5.01 & - & $<.020$ & 0.62 & 0.00 & 1.75 & 83.52 & 0.00 & 0.00 & 0.00 & 14.10 & 117 \\
\hline 390055119421901 & - & 10.7 & $<.016$ & - & 0.246 & 0.00 & 0.00 & 4.40 & 67.98 & 8.42 & 6.33 & 0.00 & 12.87 & 54 \\
\hline 390106119424301 & - & 9.74 & 1.56 & - & $<.020$ & 0.00 & 0.00 & 1.93 & 53.48 & 36.62 & 5.08 & 0.00 & 2.89 & 57 \\
\hline 385509119414801 & - & 19.5 & 6.13 & - & $<.020$ & 3.65 & 14.89 & 2.26 & 53.25 & 0.00 & 9.08 & 0.00 & 16.88 & 70 \\
\hline 385340119403601 & - & 8.12 & 1.08 & - & $<.020$ & 0.65 & 0.00 & 2.58 & 73.76 & 0.00 & 8.80 & 0.00 & 14.21 & 97 \\
\hline 385321119405002 & - & 22 & 5.3 & - & $<.020$ & 0.00 & 0.00 & 4.62 & 90.39 & 0.00 & 0.00 & 0.00 & 4.99 & 141 \\
\hline 390542119472001 & - & 7.95 & 2.03 & - & $<.020$ & 6.20 & 0.00 & 1.70 & 59.24 & 0.00 & 11.30 & 7.17 & 14.40 & 103 \\
\hline 390021119504301 & - & 1.73 & 0.511 & - & $<.020$ & 2.16 & 0.00 & 4.33 & 55.66 & 0.00 & 8.09 & 0.00 & 29.75 & 84 \\
\hline 390457119491301 & - & 1.56 & 1.79 & - & $<.020$ & 0.00 & 0.00 & 1.02 & 37.73 & 49.63 & 4.93 & 0.00 & 6.69 & 45 \\
\hline 390015119500101 & - & 2.82 & 1.7 & - & $<.020$ & 9.56 & 0.00 & 6.09 & 43.72 & 15.83 & 6.86 & 0.00 & 17.95 & 41 \\
\hline 385351119452301 & - & 23.8 & 9.48 & - & $<.020$ & 2.62 & 23.75 & 1.05 & 61.24 & 0.45 & 0.00 & 2.23 & 8.65 & 62 \\
\hline 390446119451401 & - & 253 & $<.016$ & - & 0.15 & 0.00 & 0.00 & 0.00 & 0.00 & 33.34 & 2.12 & 64.54 & 0.00 & 0 \\
\hline 390222119462401 & - & 11.1 & $<.016$ & - & 0.491 & 0.00 & 0.00 & 31.93 & 31.31 & 11.43 & 4.30 & 0.00 & 21.03 & 13 \\
\hline 390140119460501 & - & 23.4 & $<.016$ & - & 0.066 & 0.00 & 0.00 & 32.23 & 32.63 & 21.51 & 3.04 & 0.00 & 10.59 & 13 \\
\hline 385337119454701 & - & 4.75 & 3.67 & - & $<.020$ & 0.00 & 0.00 & 2.02 & 90.63 & 0.03 & 0.00 & 0.00 & 7.31 & 71 \\
\hline 385335119452301 & - & 6.27 & 2.25 & - & $<.020$ & 3.98 & 6.68 & 4.26 & 51.08 & 29.11 & 0.00 & 2.21 & 2.68 & 49 \\
\hline 385335119453501 & - & 3.69 & 2.14 & - & $<.020$ & 1.25 & 0.00 & 3.31 & 74.47 & 8.25 & 8.15 & 0.14 & 4.44 & 70 \\
\hline 385343119460601 & - & 5.89 & 5.88 & - & $<.020$ & 0.00 & 0.00 & 1.91 & 42.30 & 42.49 & 6.38 & 0.00 & 6.91 & 37 \\
\hline 385407119455901 & - & 6.67 & 6.86 & - & $<.020$ & 0.00 & 0.00 & 6.07 & 50.24 & 40.45 & 0.00 & 0.00 & 3.24 & 48 \\
\hline 385342119453101 & - & 13.7 & 11.9 & - & $<.020$ & 2.66 & 4.48 & 1.06 & 81.50 & 6.35 & 0.00 & 2.25 & 1.70 & 71 \\
\hline 385255119482301 & - & 1.06 & 0.043 & - & E. 015 & 0.00 & 0.00 & 0.00 & 41.97 & 52.56 & 2.62 & 0.00 & 2.85 & 16 \\
\hline 385328119455801 & - & 10.4 & 7.06 & - & $<.020$ & 0.00 & 0.00 & 0.00 & 63.95 & 28.17 & 0.00 & 0.00 & 7.88 & 35 \\
\hline
\end{tabular}


Appendix 2. Tritium, chlorofluorocarbon, and dissolved gas (nitrogen, argon, oxygen, carbon dioxide, and methane) data for selected wells.

[mm/dd/yyy, month/day/year; pCi/L, picocuries per liter; CFC, chlorofluorocarbon; - , no data; <, less than; R, radiochemistry non-detect, result below sample specific critical level]

\begin{tabular}{|c|c|c|c|c|c|c|c|c|}
\hline Station number & Station name & $\begin{array}{c}\text { Date } \\
\text { (mm/dd/yyyy) }\end{array}$ & Round & $\begin{array}{l}\text { Tritium, water, } \\
\text { unfiltered, } \\
\text { (pCi/L) }\end{array}$ & $\begin{array}{l}\text { CFC-11 (calen- } \\
\text { dar date) }\end{array}$ & $\begin{array}{c}\text { CFC-12 } \\
\text { (calendar date) }\end{array}$ & $\begin{array}{c}\text { CFC-113 } \\
\text { (calendar date) }\end{array}$ & $\begin{array}{l}\text { CFC-11 (years } \\
\text { before 2010) }\end{array}$ \\
\hline 390230119480001 & $\begin{array}{l}105 \text { N14 E19 25BA } 1 \\
\text { Carson Indian Colony }\end{array}$ & $08 / 28 / 08$ & Round 1 & - & 1970 & 1978 & 1978 & 39 \\
\hline 390457119491301 & 105 N14 E19 14BBD 1 & 09/03/08 & Round 1 & $<0.3$ & 1964 & 1958 & 1963 & 45 \\
\hline 390208119433201 & 105 N14 E20 34BDBD1 & $11 / 17 / 08$ & Round 1 & R 0.3 & 1982 & 1970 & 1973 & 27 \\
\hline 390257119471001 & 105 N14 E20 30BCCD1 & $11 / 17 / 08$ & Round 1 & R .0 & 1950 & 1945 & 1953 & 59 \\
\hline 390011119480901 & 105 N13 E19 12CBA 1 & $11 / 24 / 08$ & Round 1 & R.1 & 1957 & 1953 & 1962 & 52 \\
\hline 390018119485801 & 105 N13 E19 11BDD 1 & $11 / 24 / 08$ & Round 1 & $\mathrm{R}-.1$ & 1958 & 1957 & 1964 & 51 \\
\hline 390045119453801 & 105 N13 E20 05CDD 1 & $11 / 28 / 08$ & Round 1 & R.1 & 1957 & 1953 & 1959 & 52 \\
\hline 385605119381801 & 105 N12 E21 04BCAC1 & $12 / 02 / 08$ & Round 1 & 1.6 & 1966 & 1966 & 1971 & 43 \\
\hline 385610119415001 & 105 N12 E20 02AADC1 & $12 / 02 / 08$ & Round 1 & 3.4 & - & - & - & - \\
\hline 390457119491301 & 105 N14 E19 14BBD 1 & $12 / 03 / 08$ & Round 1 & $\mathrm{R}-.3$ & 1964 & 1958 & 1963 & 45 \\
\hline 385654119431801 & 105 N13 E20 34ACC 1 & $12 / 03 / 08$ & Round 1 & 11.3 & 1988 & 1985 & 1986 & 21 \\
\hline 390542119472001 & 105 N14 E19 12ADAB1 & $12 / 03 / 08$ & Round 1 & $\mathrm{R}-.2$ & 1955 & 1962 & 1961 & 54 \\
\hline 385106119462601 & 105 N11 E20 06AABB1 & $12 / 05 / 08$ & Round 1 & 9.5 & 1976 & 1983 & 1985 & 33 \\
\hline 385332119425901 & 105 N12 E20 22ADAB1 & $12 / 05 / 08$ & Round 1 & 11.7 & 1984 & 1989 & 1988 & 25 \\
\hline 385335119453501 & 105 N12 E20 20BDDD1 & $12 / 05 / 08$ & Round 1 & 12 & 1982 & 1985 & 1987 & 27 \\
\hline 390106119424301 & 105 N13 E20 02CBB 1 & $12 / 08 / 08$ & Round 1 & R.0 & - & - & - & - \\
\hline 390138119434201 & 105 N14 E20 34CDCC2 & $12 / 08 / 08$ & Round 1 & R.2 & 1965 & 1964 & 1970 & 44 \\
\hline 385939119421401 & 105 N13 E20 14ABC 1 & $12 / 08 / 08$ & Round 1 & 12 & 1962 & 1960 & 1967 & 47 \\
\hline 390233119425501 & 105 N14 E20 27DDDA1 & $12 / 12 / 08$ & Round 1 & - & 1965 & 1964 & 1973 & 44 \\
\hline 385646119451101 & $\begin{array}{l}105 \text { N13 E20 32DAB } 1 \\
\text { Town of Gardnerville } 2\end{array}$ & $12 / 15 / 08$ & Round 1 & 16 & - & - & - & - \\
\hline 385604119435601 & $\begin{array}{l}105 \text { N12 E20 4ADA } 1 \text { Town } \\
\text { of Gardnerville } 6\end{array}$ & $12 / 15 / 08$ & Round 1 & 16 & 1984 & 1987 & 1987 & 25 \\
\hline 385444119453301 & 105 N12 E20 08DCCA1 & $12 / 15 / 08$ & Round 1 & 10.6 & 1971 & No Data & 1991 & 38 \\
\hline 385742119453801 & 105 N13 E20 29BDDD1 & $12 / 16 / 08$ & Round 1 & 3.7 & 1958 & 1962 & 1962 & 51 \\
\hline 385751119470001 & $\begin{array}{l}105 \text { N13 E20 30BDBB1 } \\
\text { MINDEN NO } 4\end{array}$ & $12 / 16 / 08$ & Round 1 & 0.8 & 1956 & 1954 & 1961 & 53 \\
\hline 385652119471401 & 105 N13 E20 31BCC 1 & $12 / 16 / 08$ & Round 1 & $\mathrm{R}-.1$ & - & - & - & - \\
\hline 385441119485201 & 105 N12 E19 11DCC 1 & $12 / 17 / 08$ & Round 1 & 8.2 & 1975 & 1975 & 1983 & 34 \\
\hline 385604119392301 & 105 N12 E21 05BCDB1 & $12 / 19 / 08$ & Round 1 & 5 & 1974 & 1977 & 1981 & 35 \\
\hline 385612119470901 & 105 N12 E20 06BBDC1 & $12 / 19 / 08$ & Round 1 & 25 & 1975 & No Data & 1981 & 34 \\
\hline 385821119502201 & 105 N13 E19 22CBDD1 & $12 / 19 / 08$ & Round 1 & 0.5 & 1962 & 1965 & 1973 & 47 \\
\hline 390222119462401 & 105 N14 E20 31AAC 1 & $12 / 21 / 08$ & Round 1 & $\mathrm{R}-.2$ & - & - & - & - \\
\hline
\end{tabular}


Appendix 2. Tritium, chlorofluorocarbon, and dissolved gas (nitrogen, argon, oxygen, carbon dioxide, and methane) data for selected wells.-Continued

[CFC, chlorofluorocarbon; mg/L, milligrams per liter; - , no data; <, less than; R, Radiochemistry non-detect, result below sample specific critical level]

\begin{tabular}{|c|c|c|c|c|c|c|c|c|}
\hline Station number & $\begin{array}{l}\text { CFC-12 (years } \\
\text { before 2010) }\end{array}$ & $\begin{array}{c}\text { CFC-113 (years } \\
\text { before 2010) }\end{array}$ & $\begin{array}{c}\text { Nitrogen } \\
\text { (mg/L) }\end{array}$ & $\begin{array}{l}\text { Argon } \\
\text { (mg/L) }\end{array}$ & $\begin{array}{c}\text { Oxygen } \\
\text { (mg/L) }\end{array}$ & $\begin{array}{c}\text { Carbon dioxide } \\
(\mathrm{mg} / \mathrm{L})\end{array}$ & $\begin{array}{c}\text { Methane } \\
(\mathrm{mg} / \mathrm{L})\end{array}$ & $\begin{array}{c}\text { Excess } \\
\text { nitrogen gas } \\
\text { (mg/L) }\end{array}$ \\
\hline 390230119480001 & 31 & 31 & 21.568 & 0.6518 & 0.2152 & 17.734 & 0 & 0 \\
\hline 390457119491301 & 51 & 46 & 20.021 & 0.6631 & 4.52 & 0.87869 & 0 & 0 \\
\hline 390208119433201 & 39 & 36 & 18.972 & 0.6176 & 1.112 & 10.781 & 0 & 2 \\
\hline 390257119471001 & 64 & 56 & 20.675 & 0.703 & 0.2632 & 0.49984 & 0.0122 & 0 \\
\hline 390021119504301 & 22 & 21 & 17.991 & 0.6234 & 3.487 & 18.726 & - & 0 \\
\hline 390011119480901 & 56 & 47 & 19.498 & 0.6686 & 0.2509 & 0.34197 & 0.0010 & 0 \\
\hline 390018119485801 & 52 & 45 & 19.203 & 0.6591 & 0.2285 & 0.46073 & 0.0026 & 0 \\
\hline 390045119453801 & 56 & 50 & 18.449 & 0.6277 & 0.2569 & 1.8544 & 0.0009 & 0 \\
\hline 385605119381801 & 43 & 38 & 20.997 & 0.6934 & 5.061 & 4.896 & 0 & 0 \\
\hline 385610119415001 & - & - & - & - & - & - & - & - \\
\hline 385254119404201 & 69 & 56 & 15.104 & 0.5297 & 0.8641 & 4.1033 & 0 & 1 \\
\hline 385240119485201 & - & - & - & - & - & - & - & - \\
\hline 385456119501001 & 25 & 25 & 21.71 & 0.7302 & 4.4 & 41.158 & 0 & 0 \\
\hline 390457119491301 & 51 & 46 & 20.021 & 0.6631 & 4.52 & 0.8787 & 0 & 0 \\
\hline 385654119431801 & 24 & 23 & 17.352 & 0.6088 & 3.91 & 17 & 0 & 0 \\
\hline 390542119472001 & 47 & 48 & 19.973 & 0.6401 & 0.3206 & 5.481 & 0 & 0 \\
\hline 385106119462601 & 26 & 24 & 18.276 & 0.6323 & 0.2472 & 34.758 & 0 & 0 \\
\hline 385332119425901 & 20 & 21 & 17.223 & 0.5954 & 4.122 & 36.347 & 0 & 1 \\
\hline 385335119453501 & 24 & 22 & 19.314 & 0.6658 & 3.474 & 7.8586 & 0 & 0 \\
\hline 390106119424301 & - & - & - & - & - & - & - & - \\
\hline 390138119434201 & 45 & 39 & 20.141 & 0.6547 & 4.293 & 8.0399 & 0 & 1 \\
\hline 385939119421401 & 49 & 42 & 23.224 & 0.736 & 2.364 & 8.6035 & 0.0001 & 0 \\
\hline 390010119504101 & - & - & - & - & - & - & - & - \\
\hline 385339119490501 & 19 & 23 & 19.013 & 0.6608 & 5.682 & 35 & 0 & 0 \\
\hline 390015119500101 & - & - & - & - & - & - & - & - \\
\hline 385452119412501 & 32 & 24 & 16.939 & 0.5957 & 2.794 & 18.893 & 0 & 0 \\
\hline 385604119495901 & - & - & - & - & - & - & - & - \\
\hline 385926119451201 & 53 & 34 & 18.229 & 0.6173 & 0.2224 & 0.3558 & 0.002 & 1 \\
\hline 390233119425501 & 45 & 36 & 17.96 & 0.5838 & 1.991 & 0.38451 & 0 & 2 \\
\hline 385646119451101 & - & - & - & - & - & - & - & - \\
\hline 385604119435601 & 22 & 22 & 17.519 & 0.6171 & 0.2543 & 47.099 & 0 & 0 \\
\hline 385444119453301 & - & 18 & 19.135 & 0.6588 & 3.529 & 3.3343 & 0 & 0 \\
\hline 385742119453801 & 47 & 47 & 18.981 & 0.6586 & 0.2956 & 3.9607 & 0 & 0 \\
\hline 385751119470001 & 55 & 48 & 18.764 & 0.6458 & 0.2246 & 2.0375 & 0 & 0 \\
\hline 385652119471401 & - & - & - & - & - & - & - & - \\
\hline 385441119485201 & 34 & 26 & 19.681 & 0.6709 & 3.642 & 18.982 & 0 & 0 \\
\hline 385604119392301 & 32 & 28 & 16.875 & 0.5957 & 1.252 & 17.319 & 0 & 1 \\
\hline 385612119470901 & - & 28 & 18.816 & 0.6533 & 0.2825 & 8.8058 & 0 & 0 \\
\hline 385821119502201 & 44 & 36 & 20.539 & 0.6697 & 0.9168 & 0.026491 & 0 & 0 \\
\hline 390222119462401 & - & - & - & - & - & - & - & - \\
\hline
\end{tabular}


Appendix 3. Nitrogen and oxygen isotope data for selected wells.

[mm/dd/yyy, month/day/year; —, no data; R, Radiochemistry non-detect, result below sample specific critical level]

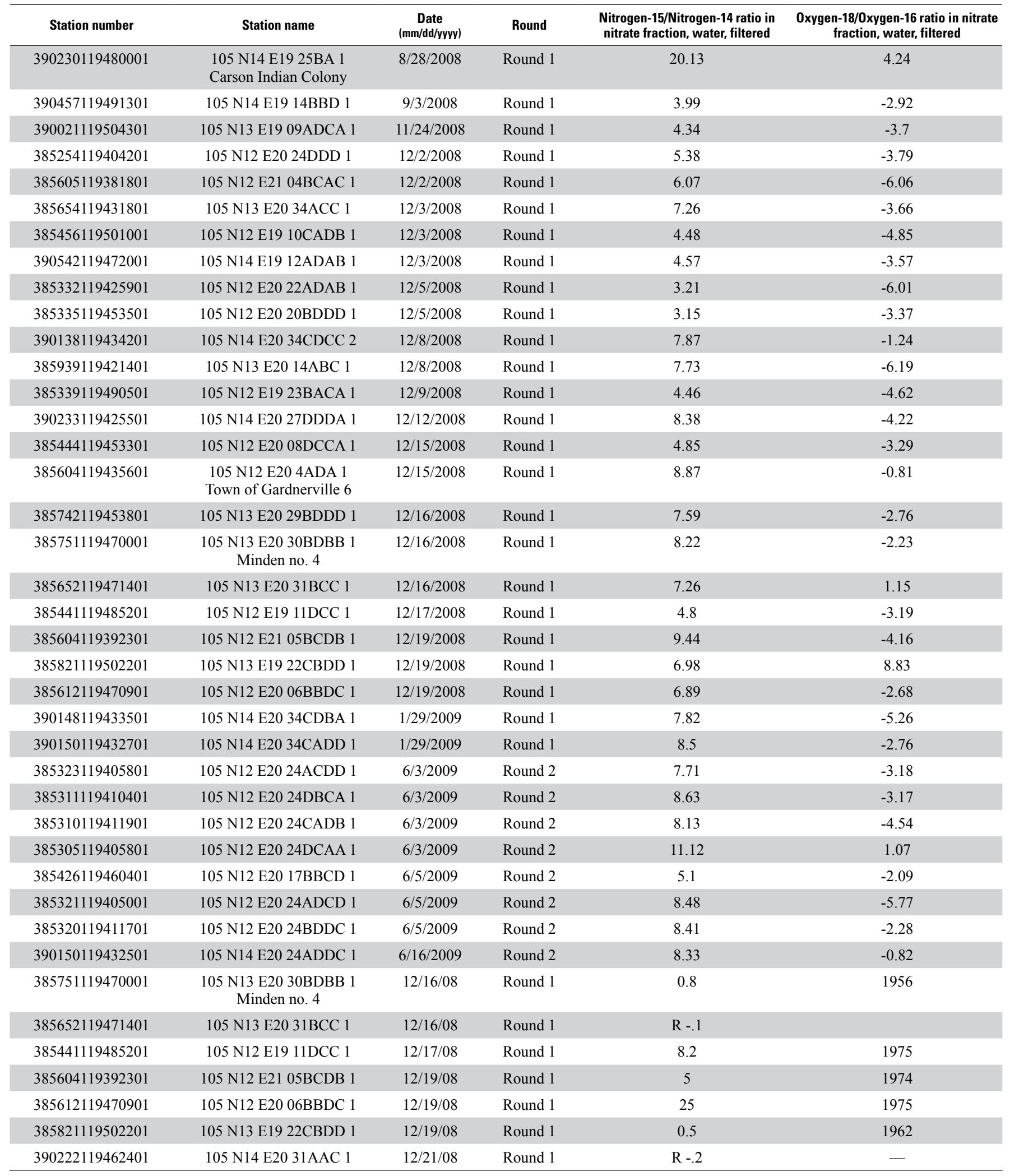


Appendix 4. Field and lab chemical data for nitrogen, bromide, and chloride for selected wells.

[mg/L, milligrams per liter; E, estimate; $<$, less than; —, no data]

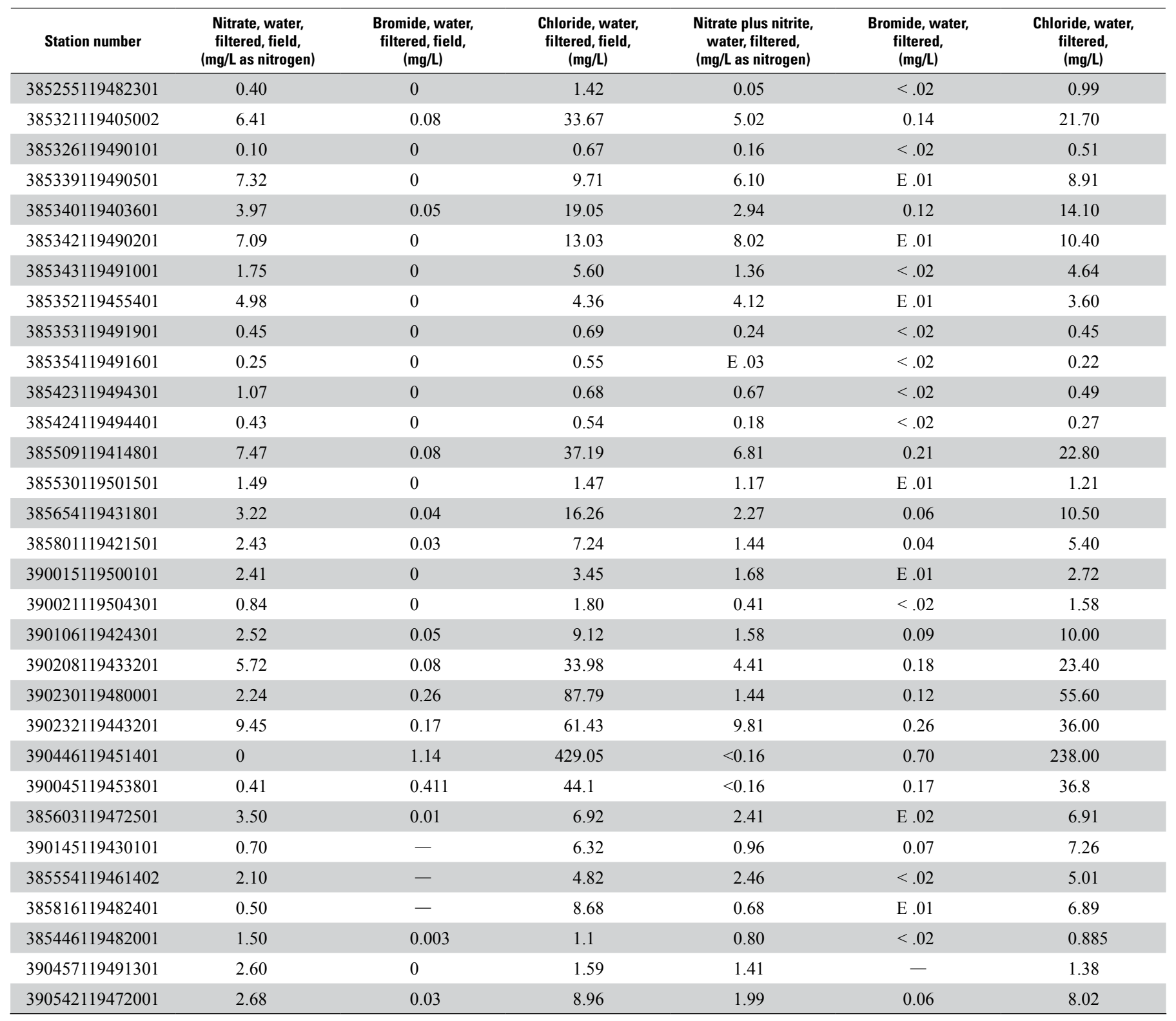




